\title{
Kişisel Verilerin Yabancı Unsurlu Sözleşmelere Aykırı Olarak İşlenmesinden veya Korunmamasından Kaynaklanan Uyuşmazlıklara
}

\section{Uygulanacak Hukukun Tespiti}

\author{
Ilyas Arslan*
}

Öz

Kişisel veriler, veri süjesi gerçek kişi ile veri sorumlusu konumundaki karşı taraf arasında akdedilen bir sözleşme çerçevesinde işlenebilmektedir. Bu veriler, genellikle bir sözleşmenin kurulmasına veya sözleşmenin ifasına ilişkin olarak işlenmektedir. Kişisel verilerin işlenmesi ve bu verilerin korunması gereği, benzer şekilde yabancılık unsuru içeren sözleşmeler bakımından da ortaya çıkabilir. Dolayısıyla, kişisel verilerin taraflar arasındaki yabancı unsurlu sözleşmeye aykııı olarak işlendiği veya korunmadığı iddiaları Türk mahkemelerinin önüne gelebilir. Bu durumda Türk mahkemelerinin, öncelikle söz konusu uyuşmazlığa uygulanacak maddi hukuk kurallarını, 5718 sayılı Milletlerarası Özel Hukuk ve Usul Hukuku Hakkında Kanun hükümleri uyarınca tespit etmesi gerekecektir. Bu çalışmanın temel amacı, henüz yabancı unsurlu sözleşmeler çerçevesinde incelenmemiş olan kişisel verilerin işlenmesi ve/veya korunması ile Türk kanunlar ihtilafi kuralları arasındaki ilişkiyi genel hatlarıyla izah etmektir. Bu itibarla, yabancı unsurlu sözleşmeler çerçevesinde elde edilen kişisel verilerin işlenmesinden veya korunmamasından kaynaklanan sözleşmeden doğan sorumluluğa uygulanacak hukukun, MÖHUK hükümleri uyarınca nasıl tespit edilmesi gerektiği meselesi ele alınmıştr.

\section{Anahtar Kelimeler}

Kişisel verilerin işlenmesi, Kişisel verilerin korunması, Yabancı unsurlu sözleşmeler, Sözleşmenin kurulması, Sözleşmenin ifası, Uygulanacak hukuk

The Applicable Law to Disputes Arising From Processing or Non-Protection of Personal Data Due to The Violation of Contracts Having Foreign Elements

\begin{abstract}
Personal data can be processed within the framework of a contract concluded between a natural person who is a data subject and the counterparty of the contract, who is the data controller. These data are generally processed for the establishment or the performance of the contracts. Similarly, the need to process and/or protect personal data may also arise in cases of contracts with foreign elements. Therefore, claims that personal data are processed in violation of contracts between the parties, or the personal data processed under the contract between the parties are not protected, may be the subject of an action before the Turkish courts. At this stage, Turkish courts should first determine the law to be applied to these disputes arising out of contracts in accordance with the provisions of the Code on Private International Law and International Civil Law no. 5718 (CPIL). The main purpose of this study is to explain the relationship between processing and/or protection of personal data, which have not yet been examined within the framework of contracts containing foreign elements in Turkish private international law and Turkish conflict of laws rules in general terms. In this respect, this study addresses the issue of determining which law is to be applied to contractual responsibility arising from processing or non-protection of personal data in violation of contracts containing foreign elements in accordance with the provisions of CPIL.
\end{abstract}

\section{Keywords}

Personal data processing, Personal data protection, Contracts containing foreign elements, Establishment of the contract, Performance of the contract, Applicable law

* Sorumlu Yazar: İlyas Arslan (Dr. Öğr. Üyesi), Yalova Üniversitesi, Hukuk Fakültesi, Milletlerarası Özel Hukuk Anabilim Dalı, Yalova, Türkiye. E-posta: ilyas.arslan243@gmail.com ORCID: 0000-0002-1567-2630

Atrf: Arslan I," Kişisel Verilerin Yabancı Unsurlu Sözleşmelere Aykırı Olarak Işslenmesinden veya Korunmamasından Kaynaklanan Uyuşmazlıklara Uygulanacak Hukukun Tespiti" (2021) 79(1) İstanbul Hukuk Mecmuası 135. https://doi.org/10.26650/mecmua.2021.79.1.0004 


\section{Extended Summary}

Personal data can be processed within the framework of a contract concluded between a natural person who is a data subject and the counterparty of the contract. These data are generally processed for the establishment or the performance of the contracts. Similarly, the need to process and/or protect personal data may also arise in cases of contracts with foreign elements. Therefore, claims that personal data are processed in violation of contract between the parties, or the personal data processed under the contract are not protected, may be the subject of an action before the Turkish courts. In this case, the substantive law rules to be applied to such claims of breach of contract will be determined in accordance with the conflict of laws rules in Arts. 24-29 of the CPIL. The questions of whether the counterparty is under an obligation to process or protect the personal data obtained for the establishment or performance of the contract and whether the scope and conditions of such an obligation are related to the substance of the contract fall within the scope of Arts. 24-29. Which of the conflict of laws rules contained in Arts. 24-29 shall apply may vary depending on the nature and the parties to the contract. If the contract falls within the scope of the special conflict of laws rules in Arts. 25-29, the law applicable to the dispute arising from the contract will be determined in accordance with the relevant rule. Otherwise, Art. 24, which is a general conflict of laws rule regarding contracts, shall be applied.

The majority of contracts requiring the processing, or the protections, of personal data of natural persons by the counterparty of the contract, take the form of consumer and employment contracts nowadays. Therefore, the law applicable to such contractual disputes arising from the processing or non-protection of personal data shall be determined in accordance with Art. 26 and Art. 27. Both articles are designed to protect consumers and workers who are deemed to be the weaker parties to the contract. Accordingly, the parties to consumer and employment contracts have been given a limited choice of law. The choice of law will only be valid if the chosen law provides more protection than the minimum protection provided by the mandatory provisions of the law of the country where the customer's habitual residence and the employee's habitual workplace are located. In the absence of a choice of law, the customer's habitual residence law and the employee's habitual workplace law will apply, respectively. In cases where the employee does not have a habitual workplace, the employer's main workplace law will apply (Art. 27(3)). In addition, if there is a law that is more closely related to the employment contract than the employee's habitual workplace (or the employer's main workplace), this law can be applied to the contract (Art. 27(4)).

Natural persons can also conclude contracts within the framework of their commercial or professional activities, and their personal data must be processed for the establishment or performance of such contracts. The law applicable to disputes 
arising from such contracts that do not fall within the scope of Arts. 25-27 of the CPIL due to unlawful processing or non-protection of personal data shall be determined in accordance with Art. 24. Accordingly, the parties may choose the applicable law within the limits stipulated in Arts. 24(1)-(3). In the absence of a choice of law, the Turkish court shall apply the law most closely connected with the contract in accordance with Art. 24(4). The determination of the law most closely connected with the contract may differ depending on whether the contract is established within the framework of a commercial or professional activity. Where the contract is established within the framework of a commercial or professional activity, this law shall be the law of the place of business of a characteristic performance obligor, and where there is no such place of business, the law of her/his domicile, and where the characteristic performance obligor has more than one place of business, the law of the place of business most closely connected with the relevant contract. Otherwise, the law of the habitual residence of the characteristic performance obligor shall apply to the contract. However, where there exists a law more closely connected with the contract under all existing circumstances, the contract shall be governed by this law (Art. 24(4)).

Where it is determined that foreign law will be applied to the contract, the Turkish courts can prevent the application of the substantive law rules of foreign law in two cases. First, the substantive law rules of foreign law only apply insofar as these rules do not constitute a clear violation of Turkish public policy (Art. 5 of CPIL). Second, it may not be possible to apply foreign law due to the application of overriding mandatory rules of Turkish law or the overriding mandatory rules of the third country closely connected with the contract. 


\section{Kişisel Verilerin Yabancı Unsurlu Sözleşmelere Aykırı Olarak İşlenmesinden Veya Korunmamasından Kaynaklanan Uyuşmazlıklara Uygulanacak Hukukun Tespiti}

\section{Giriş}

Kişisel kişisel verilerin korunması, 2010 yılında yapılan Anayasa değişikliği ${ }^{1}$ ile Türk hukukunda AY m.20'de anayasal olarak düzenlenen bir hak haline gelmiş, 6698 sayılı Kişisel Verilerin Korunması Kanunu $(\mathrm{KVKK})^{2}$ ile birlikte özel bir düzenlemeye sahip olmuştur³. KVKK ile kişisel verilerin hangi hal ve şartlar altında işlenebileceği özel olarak düzenlenmiş, böylece verileri işlemek suretiyle bireylerin kişilik haklarına müdahalede bulunan, başka bir deyişle kişisel verileri işleyen kişilerin hukuki, idari ve cezai sorumluluğuna ilişkin hükümlere yer verilmiştir. Şüphesiz, kişisel verilerin hukuka aykırı olarak işlenmesinin, ilgili bireylerin kişilik haklarının ihlal edilmesi ve bu ihlal nedeniyle maddi veya manevi zararların ortaya çıkması gibi özel hukuka yönelik sonuçları da ortaya çıkabilir. Esasen, bireylerin kişisel verilerinin kanuna aykırı olarak işlenmesi sebebiyle zarara uğramaları halinde zararın giderilmesini talep etme hakkına sahip ve bireylerin genel hükümlere göre tazminat haklarının saklı olduğunu hükme bağlayan KVKK, kişisel verilerin hukuka aykırı olarak işlenmesinden doğacak zararlardan sorumluluk bakımından genel hükümlerin uygulanacağını ortaya koymaktadır ${ }^{4}$. Buna göre, Türk vatandaşı bir gerçek kişi, kişisel verilerinin hukuka aykırı olarak işlendiği gerekçesiyle veri sorumlusu konumundaki Türk kamu kurumları veya Türk gerçek veya tüzel kişilerine karşı kişilik haklarının ihlal edildiği gerekçesiyle dava açabilecektir.

Peki, kişisel verileri hukuka aykırı olarak işlenen/işlendiğini ileri süren kişi yabancı bir devlet vatandaşı ise, böyle bir davada nasıl hareket etmek gerekecektir? İster kanun gereği isterse sözleşmenin kurulması veya ifasına ilişkin olsun, kişisel verileri işleyen ve bu verilerin güvenliğini sağlamakla yükümlü olan kişiler, yabancı devlet veya devlet kurumu veya yabancı devlet kanunlarına göre kurulmuş bir özel

Türkiye Cumhuriyeti Anayasasının Bazı Maddelerinde Değişiklik Yapılması Hakkında Kanun, Kanun Numarası: 5982, Kabul Tarihi: 7.5.2010, RG 13.5.2010/27580.

2 Kişisel Verilerin Korunması Kanunu, Kanun Numarası: 6698, Kabul Tarihi: 24.3.2016, RG 7.4.2016/29677.

Kişisel verilerin korunmasına ilişkin olarak ulusal düzenlemeler sadece bunlarla sınırlı olmadığı gibi, bu konuda pek çok uluslararası düzenleme kaleme alınmıştır. Türkiye'nin imzalayıp 2016 tarihi itibariyle iç hukukunda yürürlüğe koyduğu ve Avrupa Konseyi tarafından hazırlanan Kişisel Verilerin Otomatik İşleme Tabi Tutulması Karşısında Bireylerin Korunması Sözleșmesi buna örnek verilebilir. (RG 17.3.2016-29656). Bunun dıșında AB üyesi ülkelerde kișisel verilerin korunması konusunda yeknesak bir standardı oluşturmak amacıyla $\mathrm{AB}$ bünyesinde pek çok düzenleme yapıldığı görülmektedir. Bunlardan ilkini, KVKK'nın hazırlanmasında esas alınan 95/46/EC sayılı Veri Koruma Yönergesi olușturmaktadır. Söz konusu yönerge 2018 tarihi itibariyle yürürlüğe giren 2016/679 Sayılı Avrupa Genel Veri Koruma Tüzüğ̈̈ ile ortadan kaldırılmış, böylece Tüzük yönergeden farklı olarak üye devletlerin iç hukuklarının bir parçası haline gelerek doğrudan uygulanma gücüne sahip olmuştur.

4 Hayrunnisa Özdemir, Elektronik Haberleșme Alanında Kișisel Verilerin Özel Hukuk Hükümlerine Göre Korunması (Seçkin 2009) 95; Hüseyin Can Aksoy, Medeni Hukuk ve Özellikle Kişilik Hakkı Yönünden Kişisel Verilerin Korunması, (Çakmak 2010) 80ff; Mine Kaya, Elektronik Ortamda Kişilik Hakkının Korunması, (Seçkin 2015) 305; Damla Gürpınar, 'Kişisel Verilerin Korunamamasından Doğan Hukuki Sorumluluk', (2017) 19(Özel Sayı) DEÜHFD (Prof. Dr. Şeref ERTAŞ’a Armağan), 679, 689. 
hukuk tüzel kişisi ya da yabancı bir gerçek kişi olabilir. Yabancılık unsuru, kişisel verinin muhafaza edildiği veya paylaşıldığı yerin yabancı bir devletin ülkesinde bulunmasından da kaynaklanabilir. Kısacası kişisel verilerin hukuka aykırı olarak işlenmesi suretiyle gerçekleşen zararlardan doğan özel hukuk davalarının, veri sorumlusunun veya verileri işlenen kişinin tabiiyeti nedeniyle yabancıllk unsuru ihtiva etmesi mümkün ve muhtemeldir. Acaba kişisel verilerin işlenmesi nedeniyle ortaya çıkan ve birden fazla ülkeyle irtibatlı olan bu tür uyuşmazlıklar bakımından, milletlerarası yetkiye sahip bir Türk mahkemesinin nasıl hareket etmesi gerekecektir? $\mathrm{Bu}$ tür davalarda da, yetkili Türk mahkemesinin, ister bir sözleşmenin ifası veya kurulmasıyla ilgili olsun isterse olmasın, kişisel verilerin hukuka aykırı olarak işlenip işlenmediğini veya korunup korunmadığını tespit etmek için belirli bir yasal düzenlemeye istinat etmesi gerektiği bir gerçektir. Acaba, yabancılık unsuru içeren bu tür bir davada KVKK hükümleri veya genel hüküm mahiyetindeki Türk Medeni Kanunu $(\mathrm{MK})^{5}$ ve Türk Borçlar Kanunu (BK) $)^{6}$ hükümleri mi uygulanacaktır? Kişisel verilerin işlenmesinin aynı zamanda taraflar arasındaki sözleşmenin kurulmasının veya ifasının bir gereği olarak da ortaya çıkabilir. Acaba böyle bir durumda, verisi işlenen taraf ilgili sözleşmenin niteliğine göre Türk maddi hukuk kurallarına mı istinat etmelidir yoksa 5718 sayılı Milletlerarası Özel Hukuk ve Usul Hukuku Hakkında Kanun (MÖHUK) ${ }^{7}$ hükümleri uyarınca tespit edilen hukukun mu uygulanması gerekecektir? MÖHUK hükümlerinin uygulanması gerektiği hallerde, hangi kural veya kuralların tatbiki gerekecektir?

Çalışmamızda yukarıdaki sorulara Türk milletlerarası özel hukukuna ilişkin kurallar 1şığında cevap bulmaya çalışacak, böylece Türk hukukunda anayasal, idari, cezai ve özel hukuk yönleriyle sıkça ele alınan kişisel verilerin işlenmesi veya korunmaması nedeniyle ortaya çıkabilecek yabancı unsurlu özel hukuk uyuşmazlıklarının kanunlar ihtilafı boyutunu ele alacağız. KVKK birlikte yeni bir boyut kazanan kişisel verilerin işlenmesi ile verilerin işlenmesiyle ortaya çıkabilecek yabancı unsurlu özel hukuk uyuşmazlıkları oldukça çeşitlilik ve farklılık arz edebilir. Türk milletlerarası özel hukukunda kişilik haklarının korunması meselesinin, günümüze kadar genellikle kişilik haklarına yönelik müdahalede kullanılan internet veya medya araçları gibi

Türk Medeni Kanunu, Kanun Numaras1: 4721, Kabul Tarihi: 22.11.2001, RG 08.12.2001/24607.

Türk Borçlar Kanunu, Kanun Numaras1: 6098, Kabul Tarihi: 11.01.2011, RG 04.02.2011/27836.

Milletlerarası Özel Hukuk ve Usul Hukuku Hakkında Kanun, Kanun Numarası: 5718, Kabul Tarihi: 27.11.2007, RG 12.12.2007/26728. 
vasitalar bakımından ${ }^{8}$ veya sadece uygulanacak hukukun tespitiyle sinırlı olarak ${ }^{9}$ ele alındığı görülmektedir. Diğer yandan, kişisel verilerin işlenmesi ve bu verilerin korunması, çoğunlukla bir sözleşme ilişkisi çerçevesinde gerçekleşmektedir. Dolayısıyla, sözleşme ilişkisi çerçevesinde elde edilen kişisel verilerin hukuka aykırı olarak işlendiğini düşünen taraf, söz konusu kişisel verilerin işlenmesinin veya korunmamasının sadece kişilik haklarının değil, aynı zamanda sözleşmeye aykırılık teşkil ettiği iddiasıyla da Türk mahkemelerinde dava açabilir. Kısacası, kişisel verileri işleyen veya korumak durumunda olan ilgili tarafın sözleşmeden doğan sorumluluğuna gidilebilir. İşte bu çalışmada, kişisel verilerin işlenmesinde kullanılan yöntem veya vasıtalar bakımından herhangi bir ayrıma gidilmeksizin, yabancılık unsuru içeren sözleşmelerin kurulması veya ifasıyla ilgili elde edilen kişisel verilerin hukuka aykırı olarak işlendiği gerekçesiyle açılan yabancı unsurlu özel hukuk davalarının çözümünde uygulanacak hukukun ne şekilde tespit edilmesi gerektiği meselesi üzerinde duracağız. Bu çalışmada temel gayemiz, Türk milletlerarası özel hukuk literatüründe genellikle kişilik haklarının ihlali boyutuyla ele alınan, henüz yabancı unsurlu sözleşmeler çerçevesinde incelenmemiş olan kişisel verilerin işlenmesi ve/veya korunması ile Türk kanunlar ihtilafı kuralları arasındaki ilişkiyi genel hatlarıyla izah etmektir. Başka bir deyişle, milletlerarası karakterli sözleşmeler çerçevesinde elde edilen kişisel verilerin işlenmesi veya korunmaması nedeniyle sözleşmeden doğan sorumluluğa uygulanacak hukukun hangi hükümlere istinaden ve ne şekilde tespit edilmesi gerektiği meselesi genel olarak analiz edilecektir. Şüphesiz, kişisel verilerin işlenmesinin ve korunmasının sözleşmelere ilişkin Türk kanunlar ihtilafi hukuku boyutun genel olarak izah etmeden evvel, uygulanacak hukukun tespiti bakımından önem arz eden kişisel veri ile kişisel verilerin işlenmesi kavramlarının anlamı ve kapsamını ele almak konumuzun anlaşılması bakımından yararlı olacaktır.

\section{Kişisel Veri ve Kişisel Verilerin İşlenmesi}

Kişisel verilerin işlenmesinin hukuka aykırı olup olmadığının, dolayısıyla verileri işlenen kişinin kişilik haklarının ihlal edilip edilmediğinin tespiti için öncelikle kişisel veri kavramının kapsamına nelerin girdiğinin tespiti gereklidir. Bu tespit aynı zamanda kişisel verilerin işlenmesiyle ortaya çıkan yabancı unsurlu davalarda uygulanacak hukukun tespiti bakımından da önem arz eder. Zira Türk hukukunda kişisel veri

\footnotetext{
Bkz Sibel Özel, Uluslararası Alanda Medya ve Internette Kişilik Haklarının Korunması (Seçkin 2004) 23ff; Ayfer Uyanık Çavuşoğlu, ‘İnternet Ortamında İşlenen Haksız Fiil Sorumluluğuna Uygulanacak Hukuk' (2002) 22(2) MHB (Prof. Dr. Ergin Nomer'e Armağan) 967, 967ff; Sibel Özel, 'İnternet Yoluyla Kişilik Hakkı İhlallerinde Uygulanacak Hukuk Meselesi' (2004) 24(1-2) MHB 609, 609ff; Sibel Özel, ‘İmalâtçının Sorumluluğu ve Kitle İletişim Araçları Yoluyla Kişilik Hakkının İhlalinde Uygulanacak Hukuk’ Koç Üniversitesi Hukuk Fakültesi Dr. Nüsret-Semahat Arsel Uluslararası Ticaret Hukuku Uygulama ve Araștırma Merkezi Konferans Yayınları Dizisi-2: Avrupa'da Devletler Özel Hukuku ve Yeni Türk Milletlerarası Özel Hukuk ve Usul Hukuku Hakkında Kanun'un Akitler ve Ticaret Hukukuna İlişkin Hükümleri (Legal 2010) 219, $219 \mathrm{ff}$

9 Bkz Fatma Esenyel Hanaz, 'Kişilik Haklarının İhlalinde Sorumluluk ve Uygulanacak Hukuk' (Doktora Tezi İstanbul Üniversitesi 2018) 1ff; Seçil Etlioğlu Erçetingöz, 'İnternet Ortamında Şeref ve Haysiyetin Korunmasında Uygulanacak Hukuk' (Yüksek Lisans Tezi, Marmara Üniversitesi 2019) $1 \mathrm{ff}$
} 
kavramının anlamı ve kapsamı, dolayısıyla kişisel verilerin korunması konusundaki yaklaşım, Türk kanunlar ihtilafı kuralları uyarınca yetkili kılınan yabancı hukuktan daha farklı, daha geniş veya dar olabilir. Dolayısıyla, bu tür davaların muhatabı olan bir Türk mahkemesinin kişisel veri ve/veya kişisel verinin işlenmesi kavramlarının anlamı ve kapsamını göz önünde bulundurması da gerekecektir.

Kişisel veri, en genel anlamıla kişinin şahsi, ailevi, mesleğine ilişkin ayırt edici özelliklerini ve niteliklerini göstermeye yarayan her türlü bilgi" ${ }^{10}$ olarak ifade edilmektedir. Başka bir tanıma göre ise, "bir kişinin belirlenebilir kılınması, verilerin doğrudan ya da dolayl olarak bir gerçek kişiyle iliş̧kilendirilmesi suretiyle kişinin tanımlanabilmesi, yani şahsın o şahıs olduğunu ortaya çıkarılabilmesi özelliğidir" Kişisel veri kavramının KVKK'nın hazırlanmasında esas alınan 95/46/EC sayılı Veri Koruma Yönergesi m.2(a)'da belirli veya belirlenebilir bir gerçek kişiyle ilgili her türlü bilginin kişisel veri anlamına geldiği belirtilmektedir. Belirlenebilir kişi ise, doğrudan veya dolaylı olarak, özellikle kişinin kimlik numarası veya fiziksel, psikolojik, zihinsel, ekonomik, kültürel veya sosyal kimliğine özgü bir veya birden fazla faktöre istinaden belirlenebilen kişi olduğu ifade edilmektedir. Kişisel Verilerin Otomatik İşleme Tabi Tutulması Karşısında Bireylerin Korunması Sözleşmesi m.2(a) ve KVKK m.3(d)'de ise kişisel veri "kimliği belirli veya belirlenebilir gerçek kişsiye ilişkin her türlü bilgi”" olarak tanımlanmışı1'12.

Kişisel veri kavramının tanımından yola çıkılarak, bir bilginin kişisel veri olarak nitelendirilebilmesi için için dört temel unsura sahip olması gerektiği kabul edilmektedir. Buna göre, veri olarak nitelendirilecek bir bilginin var olması, söz konusu verinin bir gerçek kişiye ait olması ve ilgili verinin söz konusu gerçek kişiye ilişkin/gerçek kişiyle ilişkili olması gerekmektedir. Son olarak, verinin kimliği belirli veya belirlenebilir nitelikte olan bir kişiye ait olmas1 gerekmektedir ${ }^{13}$. Bu noktada, bir verinin bir gerçek kişiyi belirlenebilir kılması doğrudan ya da dolaylı olarak gerçekleşebilir ${ }^{14}$.

KVKK'da kişisel veri kavramının tanımına yer verilmekle beraber kapsamına nelerin girdiğine yer verilmemiştir. Kişisel veri kavramının içeriğinin çok geniş

10 Ersan Şen, 'Kişisel Verilerin Korunması Kanunu Tasarısı'nın Anayasa ve Türk Ceza Kanunu Hükümleri Çerçevesinde Değerlendirilmesi' (2009) 83(3) İBD 1197, 1197; Çiğdem Ayözger Öngün, Kişisel Verilerin Korunması Hukuku, (2.Bası, Beta 2019) 6.

11 Nilgün Başalp, Kişisel Verilerin Korunması ve Saklanması (Yetkin 2004) 16.

12 Benzer bir ifadeyle, kişilere ait sağllk bilgilerine özgü olarak Kişisel Sağlık Verilerinin İşlenmesi ve Mahremiyetinin

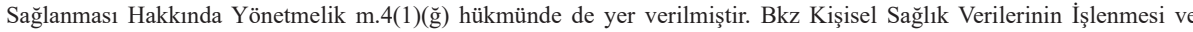
Mahremiyetinin Sağlanması Hakkında Yönetmelik, RG 20.10.2016/ 29863).

13 95/46/EC sayılı Avrupa Birliği Veri Koruma Yönergesi m.29 uyarınca kurulmuş ve kişisel verilerin korunması hususunda Avrupa Birliği bünyesinde bağımsız danışma organı olarak faaliyet gösteren Article 29 Data Protection Working Party tarafından hazırlanan "Opinion 4/2007 on the concept of personal data" adlı çalışmada kişisel veri kavramının dört temel unsura sahip olduğu ifade edilmiștir. Ayrıntılı bilgi için bkz Aksoy (n 4) 13ff; Șehriban İpek Așıkoğlu, Avrupa Birliği ve Türk Hukukunda Kişisel Verilerin Korunması ve Büyük Veri (Oniki Levha 2018) 5ff; Furkan Güven Taştan, Türk Sözleşme Hukukunda Kişisel Verilerin Korunması (Oniki Levha 2017) 26ff

14 Kişisel veri kavramının söz konusu temel unsurları hakkında ayrıntılı bilgi için bkz Article 29 Data Protection Working Party, Opinion 4/2007 on the concept of personal data, <https://ec.europa.eu/justice/article-29/documentation/opinionecommendation/files/2007/wp136_en.pdf> s.6 Erişim Tarihi 20 Ocak 2020. 
olduğu ve sınırlarının net bir şekilde çizilemediği belirtilmekle birlikte ${ }^{15}$, Türk mevzuatı, doktrin ve mahkeme kararlarlarından yola çıkarak kavramın kapsamına gerçek kişilere ait hangi bilgilerin girdiği tespit edilebilir. Örneğin, mülga Telekomünikasyon Sektöründe Kişisel Bilgilerin İşlenmesi ve Gizliliğinin Korunması Hakkında Yönetmelik ${ }^{16} \mathrm{~m} .3$ 'te "tanımlanmış ya da doğrudan veya dolaylı olarak, bir kimlik numarasl ya da fiziksel, psikolojik, zihinsel, ekonomik, kültürel ya da sosyal kimliğinin, sağllk, genetik, etnik, dini, ailevi ve siyasi bilgilerinin bir ya da birden fazla unsuruna dayanarak tanımlanabilen gerçek ve/veya tüzel kişilere ilişkin herhangi bir bilgi" kişisel veri olarak nitelendirilmiştir. Yine, Anayasa Mahkemesi bir kararında, kişinin adı, soyadı, doğum tarihi ve doğum yeri gibi sadece kimliğini ortaya koyan bilgiler değil; telefon numarası, motorlu taşıt plakası, sosyal güvenlik numarası, pasaport numarası, özgeçmiş, resim, görüntü ve ses kayıtları, parmak izleri, genetik bilgiler, IP adresi, e-posta adresi, hobileri, tercihleri, etkileşimde bulunduğu kişiler, grup üyelikleri, aile bilgileri gibi kişiyi doğrudan veya dolaylı olarak belirlenebilir kılan tüm verileri kişisel veri olarak nitelendirmiştir ${ }^{17}$.

Bunlara ilaveten, doğrudan veya dolaylı olarak bir kişi ile ilişkilendirilerek, kişinin kimliğini belirli kılan veya kılabilecek olan kimlik, etnik köken, fiziksel özellikler, sağlık, istihdam, eğitim, ikamet, emniyet, kredi kartı bilgileri, başkaları ile gerçekleştirilen haberleşmeler, telefon numarası, telefon rehberi, telefon mesajları, kişisel inanç ve ideoloji, alışveriş alışkanlıkları, maaş bordrosu, vergi mükellefiyetine ilişkin bilgiler, yüz, iris, gen izi, yazı, ses tanıma gibi yöntemlerle elde edilen verileri, kan grubu, parmak izleri, mesleği, vakıf, dernek, sendika üyelikleri, adli sicil kayıtları, ekonomik bilgileri, banka hesap numaraları, medeni durumu, sağlı bilgileri, cinsel tercihleri, sosyal medya hesapları, kişisel blog sayfasında paylaştığı yazılar gibi bilgilerin kişisel veri niteliğinde olduğu yaygın olarak kabul edilmektedir ${ }^{18}$. Bunların dışında kişi hakkında önemsiz sayılan veriler ve açık kaynaklarda yayınlanmış olan verilerin de aslında birer kişisel veri niteliğinde olduğu belirtilmektedir ${ }^{19}$.

KVKK kapsamında kişisel verilerin özel nitelikli kişisel veri veya özel nitelikli veriler dışında kalan veriler şeklinde bir ayrıma tabi tutulduğu görülmektedir ${ }^{20}$.

\footnotetext{
15 Aksoy (n 4) 12; Ayözger Öngün (n 10) 5; Ian J. Lloyd, Information Technology Law (6th edn Oxford University Press 2011) 39; M. Volkan Dülger, 'Kişisel Verilerin Korunması Kanunu ve Türk Ceza Kanunu Bağlamında Kişisel Verilerin Ceza Normlarıla Korunması (Ceza Normu)' (2016) 2(3) İMÜHFD 101, 102.

16 Telekomünikasyon Sektöründe Kişisel Bilgilerin İşlenmesi ve Gizliliğinin Korunması Hakkında Yönetmelik, RG 16.2.2004/25365. Diğer yandan, bu yönetmelik yerine yürürlüğe konan Elektronik Haberleșme Sektöründe Kișisel Verilerin İşlenmesi ve Gizliliğinin Korunması Hakkında Yönetmelik (RG: 24.7.2012/28363) m.3(h)'de ve bu yönetmeliği yürürlükten kaldıran Elektronik Haberleşme Sektöründe Kişisel Verilerin İșlenmesi ve Gizliliğinin Korunması Hakkında Yönetmelik (RG: 4.12.2020/31324) m.4(f)'de kişisel veri kavramının KVKK m.3(d) hükmüne paralel bir şekilde "kimliğ belirli veya belirlenebilir gerçek kişiye ilişkin her türlü bilgi” olarak tanımlandığı görülmektedir.

17 Anayasa Mahkemesi, 2013/122 2014/74, 9.4.2014 (RG 26.7.2014/29072).

18 Özdemir (n 4) 123-124; Ayözger Öngün (n 10) 6-7; Aksoy (n 4) 1, 11ff; Dülger (n 15) 102; Nafiye Yücedăg, 'Medeni Hukuk Açısından Kişisel Verilerin Korunması Kanunu'nun Uygulama Alanı ve Genel Hukuka Uygunluk Sebepleri’ (2017) 75(2) İ̈HHFM 765, 768.

19 Özdemir (n 4) 24

20 Söz konusu ayrım sadece KVKK'da değil, bazı farklılıklarla birlikte 95/46/EC sayılı Veri Koruma Yönergesinde de benimsenmiştir.
} 
Aynı zamanda hassas veri olarak da ifade edilen özel nitelikli kişisel veri ile normal kişisel veri arasında ayrım, söz konusu verilerin işlenmesi şartları bakımından aranan hukuka uygunluk şartları bakımından önem arz etmektedir ${ }^{21}$. Özel nitelikli kişisel veriler, esas itibariyle bir kişisel veri olmasına rağmen kişisel verilerin daha fazla koruma sağlanan küçük bir grubu olarak nitelendirilebiliir ${ }^{22}$. KVKK m.6'da kişilerin ırk1, etnik kökeni, siyasi düşüncesi, felsefi inanc1, dini, mezhebi veya diğer inançları, kılık ve kıyafeti, dernek, vakıf ya da sendika üyeliği, sağlığı, cinsel hayatı, ceza mahkûmiyeti ve güvenlik tedbirleriyle ilgili verileri ile biyometrik ve genetik verileri özel nitelikli veri kabul edilmiştir. Söz konusu maddede yer alan kişisel verilerin sınırlı sayıda olduğu ve kapsamının genişletilemeyeceği ve sadece kanunda sayılan istisnai hallerde işlenebileceği için, bu veriler bakımından kesin işleme yasağı mevcuttur ${ }^{23}$. Bunlar dışında kalan kişisel veriler ise, 5.maddede yer alan hukuka uygunluk şartlarının karşılanması kaydıyla işlenebilecektir.

Kişisel verilerin işlenmesi kavramı ile veriler üzerinde gerçekleştirilen her türlü işlemlerin kastedildiğini söylemek mümkündür. KVKK m.3(e) uyarınca kişisel verilerin tamamen veya kismen otomatik olan ya da herhangi bir veri kayıt sisteminin parçası olmak kaydıyla otomatik olmayan yollarla elde edilmesi, kaydedilmesi, depolanması, muhafaza edilmesi, değiştirilmesi, yeniden düzenlenmesi, açıklanması, aktarılması, devralınması, elde edilebilir hâle getirilmesi, sınıflandırılması ya da kullanılmasının engellenmesi gibi her türlü işlem kişisel verinin işlenmesi olarak ifade edilmiştir. Örneğin, bir bankayla kredi sözleşmesi yapılması sırasında bankanın, o kişiye ait maaş bordrosunu, tapu kayıtlarını, icra borcu olmadığına dair belgeyi edinmesi bir veri işleme faaliyetidir. Bir şirketin çalışanına maaş ödeyebilmesi için banka hesap numarası, evli olup olmadığı, bakmakla yükümlü olduğu kişiler, eşinin çalışıp çalışmadığı, sosyal sigorta numarası gibi bilgileri edinmesi de buna örnek verilebilir ${ }^{24}$. Yine, kişisel verilerin sadece bir hard diskte, CD'de veya sunucuda depolanması, anılan verilerle başkaca hiçbir işlem yapılmasa da bir veri işleme faaliyeti niteliğindedir ${ }^{25}$. Kanunda mehaz düzenlemeden esas alınarak işlemenin otomatik veya otomatik olmayan yollarla yapılabileceği öngörülmüş, böylece verinin işlenme şeklinin veya işlemede kullanılan aracın önemli olmadığı vurgulanmıştır. $\mathrm{Bu}$ bakımdan, nitelik olarak veri işleme kapsamına giren eylemler sınırlı sayıda olmayıp,

${ }^{21}$ Kişisel verilerin korunması hukukunda böyle bir ayrıma gidilmesinin sebebi, bu verilerin kamusallaştıkları takdirde bireylerin toplumdaki yerini ve diğer insanların kişiye bakış açısını değiştirme özelliğine sahip olmalarıdır. İçeriğinde inanç, politik düşünce, cinsel tercih, etnik köken, kılık kıyafet gibi unsurları bulunduran bu verilerin açıklanması kişinin "ötekileştirilmesi”" sonucunu doğurabileceği için "hassasiyet” taşıdığı belirtilmektedir. Bkz Türkay Henkoğlu, "Hassas Bilgi Varlıklarının ve Kişisel Verilerin Hukuksal Düzenlemeler ile Korunması ve Bu Kapsamda Üniversiteler İçin Bilgi Güvenliği Politikasının Geliştirilmesi' (Doktora Tezi, Hacettepe Üniversitesi 2015) 18-19, 205.

22 Özdemir (n 4) 126; Cemil Kaya, 'Avrupa Birliği 1995/46 EC Veri Koruma Direktifi Ekseninde Hassas (Kişisel) Veriler ve İşlenmesi’ (2011) 69(1-2) Ï̈̈HFM 317, 318.

23 Özdemir (n 4) 127; Yücedağ (n 18) 768; Taştan (n 13) 41.

${ }^{24}$ Kişisel Verileri Koruma Kurumu, Madde ve Gerekçesi ile Kişisel Verilerin Korunması Kanunu (Bilgi Notu) ve Kişisel Verilerin Korunmasına İlişkin Terimler Sözlüğ̈̈ (KVKK Yayınları 2019) 19.

25 Kişisel Verileri Koruma Kurumu, 6698 Sayılı Kişisel Verilerin Korunması Kanunu Hakkında Sıkça Sorulan Sorular (KVKK Yayınlar1 2018) 31. 
veri işleme kişisel verilerin ilk defa elde edilmesinden başlayarak veriler üzerinde gerçekleştirilen tüm işlem türlerini ifade etmektedir ${ }^{26}$.

\section{Kişisel Verilerin İşlenmesi Suretiyle Gerçekleşen Yabancı Unsurlu Özel Hukuk Uyuşmazlıkları Bakımından Taleplerin Yarışması ve Uygulanacak Kanunlar İhtilafı Kurallarının Tespiti}

Kişisel veri kavramını, unsurlarını, türlerini ve kapsamına bireylere ait ne tür bilgilerin girdiği ile kişisel verilerin işlenmesinin ne anlama geldiğini ana hatlarıyla ele almış bulunmaktayız. Çalışmamızda kişisel verilerin işlenmesinin kanunlar ihtilafi boyutunun sadece sözleşmelere ilişkin kısmını ele aldığımızdan, hukuka aykırı olarak işlendiği ileri sürülen bir kişisel verinin hangi konuda veya alana ilişkin olduğu veya özel nitelikli bir veri mahiyetinde olup olmadığı esasen konumuz bakımından bir önem arz etmemektedir. Çalışmamızın asıl konusunu, bir kişinin belirli bir alana (örneğin sağlık alanına) ilişkin, ister genel isterse hassas veri niteliğinde olsun, sözleşmenin bir tarafinı oluşturan gerçek kişiye ait olan ve sözleşmenin kuruluşu veya ifasıyla ilgili kişisel verilerinin sözleşmenin karşı tarafını oluşturan ve veri sorumlusu konumundaki tarafça işlenmesinin veya işlenen bu verilerin korunmamasının sözleşmeye aykırılık teşkil edip etmediği meselesi oluşturmaktadır. Yukarıda da belirttiğimiz üzere, kişisel verilerin işlenmesinin veya korunmamasının taraflar arasındaki sözleşmeye aykırılık teşkil edip etmediğine ilişkin yerel karakterli bir davada, işlenen verinin bir kişisel veri niteliğinde olup olmadığından, işlemenin hukuka uygunluk şartlarını sağlayıp sağlamadığ1 gibi kişisel verilerin özel hukuk hükümlerine göre korunmasına ilişkin pek çok husus hakkında Türk maddi hukuk kuralları uygulanacaktır. Bununla birlikte, uyuşmazlığın yabancılık unsuru ihtiva etmesi halinde, kişisel verilerin işlenmesine veya korunması meselesi, bir yönüyle bireylerin kişilik haklarıyla yakından ilgili olması nedeniyle, uyuşmazlığın bir kişilik hakkına aykırılık veya sözleşmeye aykırılık olarak nitelendirilip nitelendirilmeyeceği meselesini de beraberinde getirmektedir. $\mathrm{Bu}$ da, yapılacak nitelendirmeye bağlı olarak uygulanacak kanunlar ihtilafı kuralının, dolaylı olarak uygulanacak hukukun değişiklik arz etmesine neden olabilecektir.

Türk hukukunda kişisel verilerin, hukuki niteliği itibariyle şahsın varlığına ilişkin haklardan olduğu kabul edilmektedir. Kişisel veriler, genel olarak bireylerin kişilik haklarının kapsamına giren maddi ve manevi değerlerden oluşması itibariyle Türk maddi hukukunda kişiler hukuku alanında mütalaa edilmektedir. Kişiler hukuku alanında mütalaa edilen kişisel değerlere yönelik hukuka aykırı bir saldırı ise, haksız fiil teşkil eden bir eylem mahiyetindedir. Kısacası, kişisel verilerin işlenmesi suretiyle gerçekleşen kişilik haklarının ihlali bir haksız fiil şeklinde ortaya çıkabilecektir. Dolayısıyla, kişisel veriler, Türk hukukunun kişilik haklarına karşı sağlamış olduğu

26 KVKK, Sorular (n 22) 31; Başalp (n 11) 30-31; Özdemir (n 4) 135; Ayözger Öngün (n 10) 131. 
geniş korumadan faydalanacaktır ${ }^{27}$. Bu bakımdan, kişisel verilerin işlenmesi suretiyle kişilik hakları saldırıya uğrayan kişi, MK m.24-25 hükümleri uyarınca söz konusu saldırının önlenmesi, sürmekte olan saldırının sonlandırılmasını veya saldırının hukuka aykırıllğının tespitini isteyebilecektir. Bunun yanı sıra kişilik haklarına yönelik yukarıdaki haksız fiil niteliğindeki eylemler nedeniyle ortaya çıkan zararın tazmini amacıyla maddi veya manevi tazminat talebinde de bulunulabileceği kabul edilmektedir.

Yabancı unsurlu bir uyuşmazlıkta, yani verisi işlenenin yabancı devlet vatandaşı olduğu veya veri sorumlusunun başka bir devletin tabiiyetinde olduğu hallerde ise Türk mahkemesi, veri işleme faaliyetinin hukuka uygunluğunu, dolayısıyla kişilik haklarının ihlal edilip edilmediğini MÖHUK hükümlerine istinaden uygulanacak hukuk olarak tespit etmiş olduğu ülke hukukuna göre karara bağlamak durumunda kalacaktır. Türk milletlerarası özel hukukunda da kişilik haklarına yönelik müdahalenin haksız fiil niteliğinden yola çıkılarak, MÖHUK m.35 hükmünde kişilik haklarının ihlalinin bir haksız fiil olarak vasıflandırıldığın ${ }^{28}$ söylemek hatalı olmayacaktır. Gerçi, MÖHUK m.35 hükmü, kişilik haklarının her türlü ihlaline değil, sadece medya ve kitle iletişim araçları vasıtasıyla gerçekleşen kişilik hakları ihlalleri ile kişisel verilerin işlenmesi suretiyle gerçekleşen kişilik hakkı ihlallerine uygulanacak hukuka ilişkindir. Ancak, söz konusu hükmün Kanun sistematiğindeki yeri, kişilik haklarının ihlalinin Kanun Koyucu tarafından haksız fiil olarak vasıflandırıldığını dolaylı olarak göstermektedir. Başka bir ifadeyle, medya veya kitle iletişim araçlarıyla veya kişisel verilerin işlenmesi suretiyle gerçekleşen kişilik haklarına yönelik eylemler, bir haksız fiil olarak vasıflandırılmış, böylece söz konusu haksız fiil türü bakımından MÖHUK m.35'te özel bir kanunlar ihtilafı kuralına yer verilmişsiir ${ }^{29}$. Demek ki, kişisel verilerin işlenmesinin kişilik haklarına yönelik haksız bir eylem mahiyetinde olduğu, bu nedenle kişilik haklarının ihlal edildiğinin ileri sürüldüğü yabancı unsurlu bir davada uygulanacak hukuk MÖHUK m.35 uyarınca tespit edilecektir.

Bir kişiye ait verilerin işlenmesi, kişisel verilerin kişilik haklarından olmaș itibariyle kişilik haklarına yönelik bir müdahale niteliğinde olduğundan, veri işleme

27 Ayözger Öngün (n 10) 52-53.

28 Türk hukukunda vasıflandırma (bağlama konusu ve bağlama noktasının vasıflandırılması) hakkında ayrıntılı bilgi için bkz Aysel Çelikel ve B. Bahadır Erdem, Milletlerarası Özel Hukuk (15.Bası Beta 2020) 74ff; Ergin Nomer, Devletler Hususî Hukuku (22.Bası, Beta 2018) 96ff; Cemal Şanlı, Emre Esen ve İnci Ataman-Figanmeşe, Milletlerarası Özel Hukuk (7.Bası, Beta 2019) 45-46, 49ff; Vahit Doğan, Milletlerarası Özel Hukuk (4.Bası, Savaş 2016) 179; Rona Aybay ve Esra Dardağan, Uluslararası Düzeyde Yasaların Çatışması (Kanunlar Ihtilafi) (2.Bası, İstanbul Bilgi Üniversitesi Yayınları 2008) 47ff; Gülören Tekinalp ve Ayfer Uyanık-Çavuşoğlu, Milletlerarası Özel Hukuk-Bağlama Kuralları (11.Bası, Vedat 2011) 40ff

295718 sayılı MÖHUK öncesi dönemde de kişisel değerlere yönelik saldırıların, hususen kişisel verilerin işlenmesi suretiyle gerçekleşen saldırıların/kişilik hakkı ihlallerinin bir haksız fiil olarak vasıflandırılması gerektiği ifade edilmekteydi. Bkz Özel, Medya (n 8) 82-83; Günseli Öztekin Gelgel, Akit Dışı Borç İlişkilerine Uygulanacak Hukuk Hakkındaki Avrupa Birliği Düzenlemesi (Beta 2006) 133-134. Buna göre, her ne kadar kişilik haklarının ihlali kişisel değerlerin korunması ile ilgili olsa da, bu meselenin tek taraflı olarak kișilik hakkı ihlal edilen kișinin kişisel statüsü dikkate alınarak söz konusu kişinin milli hukukuna göre çözülmesi yerinde olmayacaktır. Zira ister medya yoluyla isterse kişisel verilerin işlenmesi suretiyle gerçekleşsin, kişilik hakkının ihlaline ilişkin yabancı unsurlu bir davada iki taraf arasında bir menfaat çatışması vardır ve çatışan menfaatlerin denkleştirilmesi, uyuşmazlığın bir haksız fiil olarak vasıflandırılmasını gerekli kılmaktadır. Bu konuda ayrıntılı bilgi için bkz Özel, Medya (n 8) 82. 
faaliyetinde bulunan kişinin söz konusu eylem nedeniyle haksız fiil sorumluluğuna gidilebileceği bir gerçektir. Diğer yandan, veri işleme faaliyetinin verisi işlenen kişi ile veri sorumlusu olarak ifade ettiğimiz kişi arasında var olan bir sözleşmesel ilişkiye dayanması ihtimali de bulunmaktadır ${ }^{30}$. Hatta kişilik haklarından olduğunu kabul ettiğimiz bir kişisel verinin işlenmesi, veri işleme faaliyetinde bulunan kişilerin kimi hallerde sözleşme öncesi görüşmelerden doğan (culpa in contrahendo) sorumluluğu dahi gündeme gelebilir. Zira kişisel verilerin işlenmesi, genellikle bir sözleşmesel ilişkinin kurulmasından önce veya sözleşmesel ilişki çerçevesinde ve sözleşmenin kurulmasına veya sözleşmenin ifasına ilişkin olarak elde edilmesi ve kullanılması hallerinde ortaya çıkmaktadır. Örneğin, işverenin işçi adayına ait başvuru formu, özgeçmiş, iletişim bilgisi diploma, sertifika, sağlık raporu gibi işçinin kişisel verileri niteliğindeki kimi bilgi ve belgeleri edinmesi ve bunları iş ilişkisi kurulsun veya kurulmasın belirli şartlar dâhilinde saklaması mümkündür. İşverenin bu verileri işçinin rızası olmaksızın üçüncü kişilerle paylaşması, verisi işlenen işçinin veya işçi adayının kişilik haklarına saldırıda bulunması anlamına gelecektir. Böyle bir durumda iş ilişkisinin işçi yönünden sürdürülmesinin işçi bakımından çekilmez hale gelmesi, iş sözleşmesinin haklı nedenle fesih nedeni sayılabilir ${ }^{31}$. Yine, bir kişi ile bir özel hastane arasında akdedilen tıbbi tedavi ve bakım sözleşmesi kapsamında hastane tarafından elde edilen hastanın sağlı durumuna ilişkin kimi bilgilerin hastanın rızası alınmaksızın reklam amacıyla umuma yayılması, hastanenin sözleşmeden kaynaklanan hastanın kişisel verileri koruma yükümlülüğüne aykırı olabilir. Bunların yanı sıra, bir gerçek kişinin ticari veya mesleki faaliyetlerini gerçekleştirmek amacıyla sözleşme akdetmesi de mümkündür. Örneğin, bir avukatın bürosunda kullanmak üzere mobilya siparişi vermesi veya mesleğini ifa ederken kullanmak üzere içtihat ve mevzuat bilgi bankalarına abone olması söz konusu olabilir. Bu tür sözleşmelerin gerek kurulabilmesi gerekse ifası amacıyla avukata ait kişisel veri niteliğindeki bilgilerin sözleşmenin karşı tarafınca kullanılması gerekecektir.

$\mathrm{Bu}$ örneklerden de anlaşılacağı üzere, veri süjesi gerçek kişi ile veri sorumlusu konumundaki karşı taraf arasında bir sözleşmenin kurulması veya ifasına ilişkin olarak elde edilen kişisel verilerin hukuka aykırı olarak işlenmesi halinde veri sorumlusunun sözleşmeye aykırı davranış nedeniyle sözleşmeden kaynaklanan sorumluluğu doğabilir. Bu tür sözleşmesel ilişkilerin çeşitli maddi veya hukuki unsurları itibariyle birden fazla hukuk düzeni ile irtibatı söz konusu olabilir. Yukarıda değindiğimiz örnekten yola çıkacak olursak, tıbbi tedavi sözleşmesinin tarafı olan gerçek kişi yabancı bir devletin vatandaşı olabilir. Haliyle, hastanenin yabancı gerçek kişiye ait sağlık verilerinin kullanmasının hukuka aykırı olduğu, bunun aynı zamanda hastanenin yabancı unsurlu sözleşmeden kaynaklanan yükümlülüğüyle bağdaşmadığı Türk mahkemelerinde tartışma konusu olabilir. Benzer bir durum,

\footnotetext{
30 Taştan (n 13) $75 \mathrm{ff}$

31 İlke Gürsel, İşçinin Kişisel Verilerinin Korunması Hakkı (Adalet 2016) 420.
} 
yabancı devlet vatandaşı işçinin kişisel verilerinin işveren tarafından iş ilişkisinden kaynaklanan kimi yükümlülüklerine (örneğin sır saklama yükümlülüğüne) aykırı bir şekilde kullanılması halinde de söz konusu olabilir. Dolayısıyla, kişisel verilerin işlenmesi suretiyle ortaya çıktığı ileri sürülen kişilik haklarına aykırılık, aynı zamanda taraflar arasında var olan ve yabancılık unsuru içeren bir sözleşmenin ihlali anlamına gelebilir. Böyle bir durumda, kişisel verilerin sözleşmenin bir tarafınca, genellikle veri sorumlusu sıfatına sahip olan tarafça işlenmesinin taraflar arasındaki sözleşmeden kaynaklanan yükümlülüklere aykırılık teşkil edip etmediği, prensip olarak doğrudan Türk hukukuna göre karara bağlan(a)mayacaktır. Artık burada, yabancılık unsuru içeren bir sözleşmesel ilişkiden kaynaklanan borca aykırılık söz konusu olduğundan, Türk mahkemeleri kişisel verilerin işlenmesi eyleminin sözleşmeye aykırılık teşkil edip etmediğini sözleşmelere uygulanacak hukuku gösteren MÖHUK m.24 vd. hükümleri uyarınca tespit edilecek ülke hukukuna göre karara bağlayacaktır. Aksi takdirde yabancı unsurlu özel hukuk uyuşmazlıklarında Türk kanunlar ihtilafı kurallarının re'sen uygulanması gerektiğini öngören m.2(1) hükümlerine riayet edilmemiş olunacaktır.

Diğer yandan, sözleşmesel ilişki kapsamında elde edilen kişisel verilerin işlenmesi eylemi, yukarıdaki ifadelerden de anlaşılacağı üzere, aynı zamanda hem haksız fiil hem de sözleşmeye aykırılık teşkil edebiliir ${ }^{32}$. Maddi hukukta benimsenen haksız fiilden kaynaklanan talepler ile sözleşmeye aykırılıktan kaynaklanan taleplerin yarışması meselesi, varlığını kanunlar ihtilafı hukukunda da muhafaza etmektedir ${ }^{33}$. Türk maddi hukukunda bir eylemin hem mutlak bir hakkın ihlali nedeniyle haksız fiil hem de borca aykırı davranma nedeniyle sözleşmeye aykırılık teşkil edebileceği, böyle bir durumda haksız fiili sorumluluğu ile akdi sorumluluğun yarışma halinde olduğu ve birbirini dışlamadığı anlayışı hâkimdir ${ }^{34}$. Böyle hallerde, söz konusu eylem nedeniyle zarar gören taraf, tazminat alacağını ister haksız fiil isterse sözleşmeden doğan sorumluluk hükümlerine göre talep edebilecektir. Türk milletlerarası özel hukukunda da zarar gören tarafın/davacının bu gibi durumlarda dilediği hükme dayanabileceğinin kabul edilmesi gerektiği, davacının yaptığı hukuki nitelendirmenin esas alınması gerektiği kabul edilmektedir. Dolayısıyla, hem haksız fiil teşkil eden hem de sözleşmeye aykırılık teşkil eden ve yabancılık unsuru içeren bir eylem nedeniyle açılan davada, davacı iddialarını sözleşmeye dayandırmışsa, uygulanacak hukuk sözleşmeden kaynaklanan borç ilişkilerine uygulanacak hukuku gösteren kanunlar ihtilafı kurallarına göre belirlenecektir. Davacının iddialarını haksız fiile dayandırması halinde, uygulanacak hukukun haksız fiillere uygulanacak hukuku gösteren kurallara göre belirleneceği kabul edilmektedir ${ }^{35}$.

\footnotetext{
Taştan (n 13) 191.

33 Şanll, Esen ve Ataman-Figanmeşe (n 28) 323.

34 Fikret Eren, Borçlar Hukuku Genel Hükümler (22.Bası, Yetkin 2017) 1166ff; Ahmet Kılıçoğlu, Borçlar Hukuku Genel Hükümler (22.Bas1, Turhan 2018) 581-582.

35 Şanl, Esen ve Ataman-Figanmeşe (n 28) 323.
} 
Buna göre, kişisel verilerin işlenmesi ve/veya korunmaması eyleminin hem kişilik haklarına yönelik haksız fiil niteliğinde bir eylem olduğu hem de veri işleme faaliyetinde bulunan kişinin sözleşmeye aykırı bir davranışta bulunduğu iddiasında olan taraf, davasını haksız fiil olarak nitelendirerek söz konusu eylemin/saldırının önlenmesini, tespitini veya uğradığı zararın tazminini isteyebilecektir. Uyuşmazlığın yabanc1lık unsuru ihtiva etmesi halinde, söz konusu yabancı unsurlu kişisel verilerin işlenmesi nedeniyle ortaya çıkan yabancı unsurlu kişilik hakkı ihlaline ilişkin davada uygulanacak hukuk, yukarıda bahsettiğimiz MÖHUK m.35(3) uyarınca tespit edilecektir ${ }^{36}$.

Davacı, davasını kişisel verilerinin işlenmesinin yabancılık unsuru içeren sözleşme hükümlerine aykırılık teşkil ettiği iddiasına da dayandırabilir. Bu durumda, veri işleme faaliyetinin sözleşmeye aykırılık teşkil edip etmediği, bu bağlamda sözleşme kapsamında edinilen kişisel verilerin işlenmesinin (korunmamasının) hukuka uygun olup olmadığ 1 meselesi, MÖHUK m.24-29 ve 32'de yer alan kanunlar ihtilafı kuralları uyarınca yetkili kılınan ülke hukukuna göre belirlenecektir. Aşağıda bir gerçek kişinin tarafı olduğu yabancı unsurlu bir sözleşme ilişkisi çerçevesinde edinilen kişisel verilerin işlenmesinin ve/veya korunmamasının sözleşmeye aykırılık teşkil edip etmediği iddiası hakkında uygulanacak hukukun MÖHUK m.24 vd. hükümlerine göre ne şekilde tespit edilmesi gerektiğini ele alacağız.

\section{Kişisel Verilerin İşlenmesi veya Korunmaması Nedeniyle Doğan Sözleşmesel Sorumluluğa Uygulanacak Hukukun Tespiti}

\section{A. Genel Olarak}

Davacı, davasını kişisel verilerinin işlenmesi suretiyle kişilik haklarının ihlal edildiğini ileri sürmek yerine, veri sorumlusu olan sözleşmenin karşı tarafinın aralarında var olan ve yabancılık unsuru içeren sözleşme hükümlerine aykırılık teşkil ettiği iddiasına dayandırabilir. Bu durumda, veri işleme faaliyetinin sözleşmeye aykırılık teşkil edip etmediği, bu bağlamda sözleşme kapsamında edinilen kişisel verilerin işlenmesinin/korunmasının hukuka uygun olup olmadığı meselesi, sözleşmelerden kaynaklanan borç ilişkilerine uygulanacak hukuku gösteren MÖHUK m.24-29'da yer alan kanunlar ihtilafı kuralları uyarınca yetkili kılınan ülke hukukuna göre belirlenecektir. Bu halde, MÖHUK m.24-29'da yer alan kanunlar ihtilafi kurallarından hangisinin uygulama alanı bulacağının tespiti gerekmektedir. Hangi kuralın uygulanacağı ise, büyük ölçüde taraflar arasındaki sözleşmenin niteliğine ve taraflarına bağlı olarak belirlenecektir.

\footnotetext{
Daha önce de zikrettiğimiz üzere, çalışmamızın kapsamı, kişisel verilerin işlenmesi veya korunması faaliyetinin herhangi bir sözleşmesel ilişki kapsamında gerçekleștirilen hallerle sınırlandırıldığından, kişisel verilerin hukuka aykırı olarak işlendiği gerekçesiyle açılan yabancı unsurlu kişilik hakkı ihlallerine uygulanacak hukukun tespiti ele alınmayacaktır.
} 
MÖHUK'ta sözleşmelerden kaynaklanan borç ilişkileri bakımından ikili bir ayrıma gidildiği görülmektedir. Bunlardan MÖHUK m.24 yabancı unsurlu sözleşmelerden doğan borç ilişkilerine uygulanacak hukuku gösteren genel kanunlar ihtilafı kuralı niteliğinde iken, MÖHUK m.25-29 arasında ise bazı sözleşme türleri bakımından özel kanunlar ihtilafı kurallarına yer verilmiştir. Buna göre, MÖHUK m.25-29 hükümlerinin kapsamında giren sözleşmelere uygulanacak hukuk ilgili özel kanunlar ihtilafı kuralına göre belirlenecek, bu hükümlerin kapsamına girmeyen sözleşmelerin tabi olacağı hukuk ise MÖHUK m.24'e göre belirlencektir ${ }^{37}$.

Sözleşme kapsamında kişisel verileri işlenen, yani kişisel verileri elde edilen, kaydedilen, depolanan, değiştirilen, açıklanan, aktarılan veya devranılan ya da elde edilebilir hale getirilen, dolayısıyla kişisel verilerinin sözleşmeye aykırı bir şekilde işlendiğini ileri süren taraf, doğal olarak ve sadce bir gerçek kişi olacaktır. Bu bakımdan, MÖHUK m.24-29 hükümleri, her türlü yabancı unsurlu sözleşmeye değil, en az bir tarafının gerçek kişi olduğu yabancı unsurlu sözleşmeler çerçevesinde kişisel verilerin sözleşmeye aykırı bir şekilde işlendiği veya korunmadığı iddiaları bakımından uygulama alanı bulacaktır. Aşağıda anlatacağımız üzere, gerçek kişilerin tarafı olduğu ve genellikle karşı tarafın bu kişiye ait kişisel verilerini -sözleşme gereği- işlemek ve korumak durumunda olduğu sözleşmelerin büyük bir kısmını tüketici sözleşmeleri ile iş sözleşmelerinin oluşturduğunu söyleyebiliriz. Zira yukarıdaki örneklerden de anlaşılacağı üzere, genellikle tüketici veya iş sözleşmesinin tarafı olan gerçek kişilere ait kişisel verilerin, sözleşmenin karşı tarafı olan satıcı/ sağlayıcı veya işveren tarafindan sözleşmesinin kurulması ve/veya ifası amacıyla kullanılması gerekecektir. Dolayısıyla, tüketici/işçi söz konusu verilerin hukuka aykırı olarak işlendiğini, bu kişilerin aynı zamanda söz konusu sözleşmeye aykırı davrandığını ileri sürülebilir. Bu itibarla, -sırasıyla- yabancı unsurlu tüketici ve iş sözleşmelerinden doğan uyuşmazlıklara uygulanacak hukuku gösteren MÖHUK m.26 ve m.27 hükümleri uygulama alanı bulacaktır.

Bunun dışında kalan, gerçek kişilerin tarafı olduğu ancak MÖHUK m.26 ve m.27'nin kapsamına girmeyen yabancı unsurlu sözleşmelerden bakımından, daha doğrusu söz konusu sözleşmelerden doğan yükümlülüklere aykırı olarak gerçekleşen veri işleme faaliyetinden doğan sözleşmesel sorumluluğa uygulanacak hukuk, genel hüküm mahiyetindeki MÖHUK m.24 uyarınca belirlenecektir. Örneğin, bir tüketici veya işçi sıfatına sahip olmayan bir gerçek kişiye ait kimi kişisel verilerini sözleşmenin karşı tarafınca -sözleşmenin kurulması veya ifasına ilişkin elde edilmiş olmak kaydıyla- hukuka aykırı olarak kullanılmış veya aktarılmış olması söz konusu olabilir. İşte bu başlık altında, kişisel verilerin işlenmesinin taraflar arasındaki sözleşmeye aykırılık teşkil ettiği iddialarına uygulanacak hukukun MÖHUK m.24 vd. hükümlerine göre ne şekilde tespit edilmesi gerektiğini ele alacağız. Şüphesiz

Şanlı, Esen ve Ataman-Figanmeşe (n 28) 272; Çelikel ve Erdem (n 28) 394-395. 
bu, fikri mülkiyet haklarına ilişkin ve eşyanın taşınmasına ilişkin sözleşmelerin bir tarafının gerçek kişi olmayacağı ve bu gerçek kişiye ait kişisel verilerin karşı tarafça hukuka aykırı olarak işlenmeyeceği/korunmayacağı anlamına gelmemektedir. Ancak, bu sözleşmeler bakımından uygulanacak hukukun tespiti ile MÖHUK m.24'ün kapsamına giren sözleşmelere uygulanacak hukukun tespiti arasında, karakteristik edim borçlusunun Kanun koyucu tarafindan bu maddelerde açıkça belirlenmiş olması dışında büyük bir benzerlik bulunmaktadır. Dolayısıyla, kişisel verilerin işlenmesinden kaynaklanan sözleşmesel sorumluluğa uygulanacak hukuka ilişkin genel kural niteliğindeki MÖHUK m.24'e ilişkin açıklamalarımız MÖHUK m.28 ve m.29'un kapsamına giren sözleşmeler bakımından da geçerli olacaktır.

\section{B. Kişisel Verilerin Yabancı Unsurlu Tüketici Sözleşmelerine Aykırı Olarak İşlenmesi veya Korunmaması Halinde Uygulanacak Hukukun Tespiti}

\section{Kişisel Verilerin İşlenmesi veya Korunması ile Tüketici Sözleşmeleri Arasındaki İlişki}

Kişisel verilerin işlenmesi, genellikle bir sözleşmesel ilişkinin kurulmasından önce veya sözleşmesel ilişki çerçevesinde ve sözleşmenin kurulmasına veya sözleşmenin ifasına ilişkin olarak elde edilmesi ve kullanılması hallerinde ortaya çıkmaktadır. Örneğin, bir kişi ile banka veya bir telekomünikasyon kurumu arasında kredi sözleşmesi veya abonelik sözleşmesi kurulabilmesi için banka veya kurum, söz konusu kişinin anne kızlık soyadı da dâhil kişisel bilgileri, iş bilgileri, mali durumu veya sağlık durumu hakkında çeşitli bilgileri sözleşmenin kurulması için isteyebilmektedir. Yine, internetten satın alınan bir malın, satıcı tarafindan teslim edilebilmesi için adres ve iletişim bilgilerinin istenmesi de sözleşmenin ifasıyla ilgilidir. Örnek kabilinden verdiğimiz bu ve benzeri pek çok durumda, gerçek kişiler ile kredi veren, satıcı, sağlayıcı gibi kişiler arasında akdedilen sözleşmelerin çoğu tüketici sözleşmesi niteliğindedir. Dolayısıyla, tüketici sözleşmesinin kurulması veya ifasıyla doğrudan ilgili olan kişisel verilere bu kişilerce erişilmesi, belirli bir süre depo edilmesi veya kullanması ya da bunların saklanması veya aktarılması sözleşmenin bir gereği olarak ortaya çıkabilir.

İşte, tüketiciye ait kişisel bilgilerin satıcı, sağlayıcı veya hizmet veren tarafından sözleşmeden kaynaklanan borcun tam ve doğru bir şekilde ifa edilmesi amaciyla işlenmesi veya bu verilerin korunması, sözleşmeden kaynaklanan bir yan yükümlülük olarak ortaya çıkabiliri ${ }^{38}$. Zira doktrinde kişisel verilerin işlenmesinin, sözleşmeden kaynaklanan asli yükümlülüğün yerine getirilmesini sağlayan, ifaya yardımcı bir yan yükümlülük niteliğinde olduğu belirtilmektedir ${ }^{39}$. Örneğin, elektronik haberleşme

\footnotetext{
Taştan (n 13) 104ff

39 Taştan (n 13) 106.
} 
sektöründe faaliyet gösteren bir şirket, abonelerine karşı olan asli yükümlülüklerini abonelere ait kişisel verileri işlemek suretiyle yerine getirmektedir. Söz konusu kişisel verilerin amaç dışı yetkisizce veya yanlış bir şekilde işlenmesi halinde de hukuka aykırı bir işleme, dolayısıyla ifaya yardımcı yan yükümlülügün ihlali gündeme gelecektir. Bu da, sözleşmenin gereği gibi ifa edilmemesi anlamına gelmektedir ${ }^{40}$. Sözleşmeye aykırılık, aynı zamanda sözleşme ilişkisi çerçevesinde edinilen kişisel verilerin, KVKK anlamında veri sorumlusu olan satıc1/sağlayıcı tarafindan korunmaması halinde de ortaya çıkabilir. Bir kira sözleşmesinde kiraya verenin sözleşme ilişkisi dolayısıyla kiracıya ilişkin edindiği verileri ifşa etmemesi buna örnek verilebilir. Yine, mobil uygulamalı satı̧s sözleşmesinde, satıcının tüketicinin cihazında bulunan ve satım sözleşmesiyle veya uygulamayla ilgili olmayan kişisel verilerini edinmemesi ve zarar vermemesi, bir yan yükümlülük olan kişisel verileri koruma yükümlülüğ̈̈n bir gereğidir ${ }^{41}$.

$\mathrm{Bu}$ tür sözleşmeler, bir tarafını yabancı bir gerçek kişinin veya satıcı veya sağlayıcının yabancı olması itibariyle ya da sözleşme konusu edim(ler)in yabancı ülkede ifa edilecek olması itibariyle yabancılık unsuru ihtiva edebilir. Dolayısıyla, tüketici karşısında satıcı/sağlayıcı konumunda olan taraflarca kişisel verilerin hukuka aykırı olarak işlenmesi veya elde edilen kişisel verilerin korunmaması halinde, yabancı unsurlu bu tüketici sözleşmesinden doğan uyuşmazlığın hangi ülke hukukuna göre karara bağlanacağı meselesi doğacaktır. Bu bağlamda, satıc1/sağlayıc1 konumunda olan tarafın, yukarıda birbirinden farklı nitelikte olan yükümlülüklerine aykırı davranıp davranmadığı, sözleşmeye aykırılı̆̆ın hangi hal ve şartlar altında söz konusu olabileceği, sözleşmeye aykırıllk halinde tüketicinin ne tür haklara sahip olduğu gibi meseleler, tüketici sözleşmesine uygulanacak hukuk uyarınca karara bağlanacaktır.

\section{Uygulanacak Hukukun Tespiti}

\section{a. Uygulanacak Kanunlar İhtilafı Kuralının Tespiti}

Türk hukukunda yabancı unsurlu tüketici sözleşmelerine uygulanacak hukuk konusunda MÖHUK m.26'da özel bir kanunlar ihtilafı kuralına yer verildiği görülmektedir. Kişilerin tüketici sıfatıyla yaptıkları sözleşmeler bakımından, sözleşmenin karşı tarafına nazaran daha tecrübesiz ve zayıf konumda oldukları varsayımından hareketle maddi hukukta benimsenen tüketicinin korunması gerektiğine yönelik bakış açısı, yabancı unsurlu tüketici sözleşmeleri bakımından

\footnotetext{
40 Özdemir (n 4)105; Ayözger Öngün (n 10) 231.

41 Taştan (n 13) 106-107.
} 
da muhafaza edilmiştir ${ }^{42}$. Bu bakımdan, tüketicinin korunması gerektiğine yönelik anlayışın kanunlar ihtilafı boyutunu bu hükmün oluşturduğunu söylemek yanlış olmayacaktır.

Bununla birlikte, kişisel verilerin işlenmesini veya korunmasını gerektiren bir tüketici sözleşmesinin MÖHUK m.26'nın kapsamına giren bir sözleşme niteliğinde olup olmadığının tespiti gerekmektedir. Zira "tüketici sözleşmeleri” başlığını taşıyan MÖHUK m.26 hükmü incelendiğinde, maddenin her türlü yabancı unsurlu tüketici sözleşmeleri bakımından uygulama alanı bulmayacağı anlaşılmaktadır ${ }^{43}$. Bu nedenle, MÖHUK m.26'nın kapsamına giren tüketici sözleşmeleri ile söz konusu maddenin kapsamına girmeyen tüketici sözleşmeleri şeklinde bir ayrımdan hareket ederek uygulanacak hukuku tespit etmek sistematik olarak daha uygun olacaktır. Buna göre, MÖHUK m.26'nın kapsamına giren tüketici sözleşmelerine uygulanacak hukuk, bu maddede yer alan kanunlar ihtilafı kurallarına göre tespit edilecek, MÖHUK m.26'nın kapsamına girmeyen tüketici sözleşmelerine uygulanacak hukuk MÖHUK' daki diğer hükümlere göre belirlenecektir. Dolayısıyla, kişisel verilerin işlenmesinin/korunmamasının yabancı unsurlu bir tüketici sözleşmesine aykırılık teşkil edip etmediğine uygulanacak hukukun tespiti bakımından böyle bir ayrımdan hareket edilmesi gerektiğini söyleyebiliriz.

\section{b. Tüketici Sözleșmesi Kavramı ve Vasıflandırılması}

Yabancı unsurlu tüketici sözleşmelerine uygulanacak hukukun yukarıda değindiğimiz hükümlere göre tespiti için öncelikle taraflar arasındaki sözleşme ilişkisinin bir tüketici sözleşmesi niteliğinde olup olmadığı belirlenmelidir. Kişisel verilerin işlenmesini veya korunmasını gerektiren böyle bir sözleşmenin bir tüketici sözleşmesi niteliğinde olup olmadığının tespiti, hangi kanunlar ihtilafi kuralının uygulanacağı konusunda belirleyici olacaktır. Diğer yandan, ilginç bir şekilde MÖHUK m.26(2)'de “mesleki veya ticari olmayan amaçla mal veya hizmet ya da kredi sağlanmasına yönelik tüketici sözleşmeleri” şeklinde bir tanıma da yer verildiği görülmektedir. Acaba Türk mahkemesi, kişisel verilerinin tüketici sözleşmesine aykırı bir şekilde işlendiği gerekçesiyle dava açan veri süjesinin nitelendirmesinden farklı olarak, taraflar arasındaki sözleşmesel ilişkinin bir tüketici sözleşmesi niteliğinde

\footnotetext{
42 Nitekim MÖHUK m.26'nın gerekçesinde de “Devletin ekonomik ve sosyal politikasının önemli bir unsuru olan tüketici, bu sözleşmenin nitelendirilmesini geniş ölçüde etkilemektedir. Bu sebeple, maddenin ikinci fikrasinda düzenlenen şartlar altında yapılan tüketici sözleşmelerinde, karşı tarafa nazaran daha zayıf ve tecrübesiz olan tüketicinin korunması ekonomik ve sosyal dengenin sağlanmasında önemli unsurlardan birini teșkil etmektedir." ifadesiyle bu husus ortaya konmuștur. Bkz Günseli Öztekin Gelgel ve B. Bahadır Erdem, Milletlerarası Özel Hukuk ve Usul Hukuku Hakkında Kanun (5.Bası, Beta 2016) 91. Milletlerarası özel hukukta tüketicinin korunması hakkında ayrıntılı bilgi için bkz Çelikel ve Erdem (n 28) 416; Gülin Güngör, Milletlerarası Özel Hukukta Tüketicinin Korunması (Yetkin 2000) 55ff; Zeynep Çalışkan, '5718 Sayı1ı Milletlerarası Özel Hukuk ve Usul Hukuku Hakkında Kanun’un 26. Maddesine Göre Tüketici Sözleşmelerine Uygulanacak Hukuk' (2008) 28(1-2) MHB 28ff

43 Çelikel ve Erdem (n 28) 405; Nomer (n 28) 350-351; Şanlı, Esen ve Ataman-Figanmeşe (n 28) 299; Ali Gümrah Toker, '5718 Sayı1ı MÖHUK’ta Düzenlenen Tüketicinin Korunmasına Yönelik Hükümler' (2016) 81(3) İzmir Barosu Dergisi 11, 17.
} 
olup olmadığını nasıl belirleyecektir? Türk hukukunda tüketici işlemi/sözleşmesi kavramına verilen anlam ve içerik ile MÖHUK m.26'da verilen tanım birbiriyle örtüşmekte midir?

Yukarıda da belirttiğimiz üzere, kişisel verilerin işlenmesinin/korunmamasının yabancıunsurlutüketici sözleşmesine aykırı olup olmadığınıtespitetmek durumunda olan bir Türk mahkemesi, uyuşmazlığa MÖHUK m.26'nın uygulanıp uygulanmayacağını tespit etmeden evvel, vasıflandırma ile somut uyuşmazlığın bir tüketici sözleşmesi niteliğinde olup olmadığını belirlemelidir. Taraflar arasındaki uyuşmazlı̆̆ın kaynağını oluşturan sözleşmenin bir tüketici sözleşmesi niteliğinde olup olmadığı, bu bağlamda tüketici sözleşmesinin ne anlama geldiği, Türk hukuku (lex fori) uyarınca yapılacak vasıflandırma ile belirlenecektir ${ }^{44}$. Buna göre Türk mahkemesi, önüne gelen böyle bir uyuşmazlıkta tüketici sözleşmesini Türk (maddi) hukuku uyarınca öngörülen hukuki kalıba oturtacaktır. Bu konuda, Türk hukukunda tüketicinin tarafı olduğu işlemlerin hukuki rejimini düzenleyen 6502 sayılı Tüketicinin Korunması Hakkında Kanun $(\mathrm{TKHK})^{45}$, kimlerin tüketici olarak nitelendirileceği ile hangi tür sözleşmelerin tüketici sözleşmesi olarak nitelendirilebileceği konusunda yol gösterici olacaktır.

TKHK m.3(k)'de ticari veya mesleki olmayan amaçlarla hareket eden gerçek veya tüzel kişi tüketici olarak tanımlanmıştır. Kanunda tüketici sözleşmesi de oldukça geniş tutularak, kamu tüzel kişileri de dâhil olmak üzere ticari veya mesleki amaçlarla hareket eden veya onun adına ya da hesabına hareket eden gerçek veya tüzel kişiler ile tüketiciler arasında kurulan, eser, taşıma, simsarlık, sigorta, vekâlet, bankacılık ve benzeri sözleşmeler de dâhil olmak üzere her türlü sözleşme ve işlem tüketici işlemi olarak nitelendirilmiştir (m.3(l)). Dolayısıyla, taraflardan birinin tüketici diğer tarafin satıcı/sağlayıcı veya mesleki faaliyeti gereği gelir elde etmek için bu işi yapan kişi olması halinde taraflar arasındaki sözleşme tüketici sözleşmesi olarak kabul edilecektir. Bu bakımdan, taraflar arasındaki sözleşmenin niteliğinin ve adının önemi bulunmamaktadır ${ }^{46}$.

Türk maddi hukukunda yapılan bu nitelendirmenin, MÖHUK m.26(1)'de yer alan "mesleki veya ticari olmayan amaçla mal veya hizmet ya da kredi sağlanmasına yönelik tüketici sözleşmeleri” tanımıyla da örtüştügünü söyleyebiliriz ${ }^{47}$. Zira TKHK m.3(k)'da tüketici olarak tarif edilen kişinin ticari veya mesleki olmayan amaçlarla hareket eden bir kişi olması gerektiği zaten vurgulanmıştır. Dolayısıyla, bir kişinin kâr elde etmek amacı olmaksızın kendisi veya ailesi için yapmış olduğu mutad tüketime ilişkin mal, hizmet veya kredi sağlanmasına yönelik bir sözleşme, yabancılık unsuru da ihtiva etmesi halinde MÖHUK m.26(1) anlamında bir tüketici

\footnotetext{
Şanl, Esen ve Ataman-Figanmeşe (n 28) 299 dn.454; Toker (n 43) 16-17.

45 Tüketicinin Korunması Hakkında Kanun, Kanun Numarası: 6502, Kabul Tarihi: 7.11.2013, RG 28.11.2013/28835.

46 Bu konuda bkz Aydın Zevkliler ve Çağlar Özel, Tüketicinin Korunması Hukuku (Seçkin 2016) 77ff; Murat Aydoğdu, Tüketici Hukuku Dersleri (Seçkin 2015) 58ff

47 Şanlı, Esen ve Ataman-Figanmeşe (n 28) 299 dn.354; Zeynep Derya Tarman, 'Milletlerarası Özel Hukukta Tüketicinin Korunması' (2019) 39(1) PPIL 325, 330
} 
sözleşmesi sayılacaktır ${ }^{48}$. Buna göre, bir mesleğin ifası için gerekli olan bir aracın temin edilmesine veya hizmetin sağlanmasına, örneğin bir avukatın bürosu için mobilya satın alması veya içtihat ve mevzuat bilgi bankalarına abone olması halinde bu sözleşmeler tüketici sözleşmesi olarak nitelendirilemeyecektir. Keza, iki tacir arasında veya üreticiler arasında bir malın tedarik edilmesine ya da aracın temin edilmesine ilişkin sözleşmeler de tüketici sözleşmesi olarak nitelendirilemeyecektir.

Yine, MÖHUK m.26(1)'deki tanımda tüketici sözleşmesinin mal veya hizmet ya da kredi sağlanmasına yönelik olması gerektiği belirtilmektedir. Burada yer alan "mal", "hizmet" veya "kredi" sağlanması kavramlarının vasıflandırılması (hukuki nitelendirilmesi) da Türk hukukuna göre yapılacaktır ${ }^{49}$. Böylece, tüketici sözleşmesinin konusunun bir malın veya hizmetin ya da kredinin sağlanmasının oluşturup oluşturmadığı TKHK'da söz konusu kavramların anlamı ve içeriği dikkate alınarak belirlenecektir. TKHK' daki tüketici işlemine konu olabilecek mal ve hizmet kavramlar1 ${ }^{50}$ ile kredi sözleşmesi ${ }^{51}$ kavramının oldukça geniş bir kapsama sahip olduğu göz önüne alındığında, MÖHUK m.26(1)'deki tüketici sözleşmesi tanımının TKHK'dan çıkan tüketici sözleşmesi tanımını fazlasıyla karşıladığını söyleyebiliriz ${ }^{52}$.

Sonuç olarak, bir kişinin mesleki veya ticari olmayan amaçlarla, yani kendisi veya ailesi için yapmış olduğu mal teminine veya hizmet sunulmasını ya da kredi sağlanmasına yönelik akdetmiş olduğu her türlü sözleşme tüketici sözleşmesi olarak nitelendirilecektir. Bu bakımdan, TKHK hükümleri karşısında MÖHUK m.26'da yer alan tüketici sözleşmesine ilişkin tanımın maddenin tatbiki bakımından herhangi bir farklılık arz etmediğini söyleyebiliriz. Ayrıca, tüketici sözleşmesi kapsamında sözleşmenin kurulmasına veya ifasına yönelik kişisel verileri işlenecek olan veya verileri korunması gereken kişilerin sadece gerçek kişi tüketiciler olacağı da unutulmamalıdır. Her ne kadar TKHK'da tüzel kişiler de tüketici olarak kabul edilmişse de, KVKK uyarınca veri süjesi, yani kişisel verileri işlenen kişiler sadece gerçek kişiler olabilecektir. Zaten MÖHUK m.26'da uygulanacak hukukun tespitinde tüketicinin mutad meskeninin esas alınmış olması, söz konusu düzenlemede gerçek kişi tüketicinin esas alındığını dolaylı olarak ortaya koymaktadır ${ }^{53}$.

48 Nomer (n 28) 350; Tarman, Tüketici (n 47) 329-330.

49 Toker (n 43) 19.

50 TKHK m.3(h)'de mal kavramı "Alıșverișe konu olan; tașınır eşya, konut veya tatil amaçlı taşınmaz mallar ile elektronik ortamda kullanılmak üzere hazırlanan yazılım, ses, görüntü ve benzeri her türlü gayri maddi mallar” şeklinde tanımlanmışken, m.3(d)'de ise hizmet Bir ücret veya menfaat karşılığında yapılan ya da yapılması taahhüt edilen mal sağlama dışındaki her türlü tüketici işleminin konusunu" ifade etmektedir.

51 TKHK'da kredi sağlanmasına yönelik sözleşme veya kredi sözleşmesi ifadeleri yer almamakla beraber, TKHK m.22(1)'de tüketici kredisi sözleşmesi tanımına yer verildiği görülmektedir. Buna göre, "kredi verenin tüketiciye faiz veya benzeri bir menfaat karşılığında ödemenin ertelenmesi, ödünç veya benzeri finansman şekilleri aracılığıyla kredi verdiği veya kredi vermeyi taahhüt ettiği sözleşme" tüketici kredisi sözleşmesi olarak tanımlanmıştır.

52 Bu nedenle, MÖHUK m.26(2)'deki tanımın TKHK'daki tüketici sözleşmesi tanımının bir tekrarı mahiyetinde olduğu, ayrıca söz konusu maddede böyle bir tanıma yer verilmiş olmasının gereksiz olduğu da belirtilmektedir. Bkz Şanlı, Esen ve Ataman-Figanmeșe (n 28) 299 dn.454.

53 Bu yönde bkz Şanl1, Esen ve Ataman-Figanmeşe (n 28) 299 dn.450; Sedat Sirmen, Milletlerarası Özel Hukukta Culpa in Contrahendo Sorumluluğuna Uygulanacak Hukukun Tayini (Yetkin 2016) 163; Hatice Selin Pürselim, 'Milletlerarası Özel Hukukta Tüketici Sözleşmelerine Uygulanacak Hukuk' iç Sibel Özel ve Mustafa Erkan (edr), Milletlerarası Özel Hukukta Sözleşmesel Meseleler (Oniki Levha 2018) 73, 78 . 


\section{c. MÖHUK m.26 Kapsamına Giren Tüketici Sözleşmelerine Uygulanacak Hukukun Tespiti}

\section{aa. MÖHUK m.26'nın Kapsamı ve Uygulama Alanı}

Tüketici sözleşmesinin karşı tarafına nazaran daha zayıf ve tecrübesiz olan tüketicinin korunması ihtiyacını dikkate alan Kanun Koyucu, bu amaçla MÖHUK m.26'da özel bir kanunlar ihtilafi kuralına yer vermiştir. MÖHUK m.26 genel olarak incelendiğinde, akdi borç ilişkilerine ilişkin diğer MÖHUK hükümleri ile kıyasladığında tüketici sözleşmeleri bakımından tüketicinin korunması amacıyla sınırlı bir hukuk seçimine izin verildiği görülmektedir. MÖHUK m.26(2)'de öngörülen objektif bağlama kuralı uyarınca tüketicinin mutad meskeni hukukunun uygulanacağı öngörülmüş, ancak tüketicinin mutad meskeni hukukunun uygulanması için tüketici sözleşmesinin belirli özellikler ihtiva etmesi şartı aranarak tüketicinin kendi yaşadığı yerin standartları ile korunması amaçlanmıştır.

MÖHUK m.26'nın kapsamına giren tüketici sözleşmelerinin kurulması veya ifasına ilişkin olarak gerçek kişi tüketiciye ait kişisel verilerin hukuka aykırı olarak işlenmesi veya bunların korunmaması nedeniyle tüketici sözleşmelerine aykırılık teşkil edip etmeyeceği meselesine uygulanacak hukuk, MÖHUK m.26(1) ve (2)'de yer alan subjektif ve objektif bağlama kuralları uyarınca belirlenecektir. Bu kurallar uyarınca yetkili kılınan hukuk, öncelikle tüketici sözleşmesiyle karşı tarafın sözleşmenin kurulması veya ifası amacıyla gerçek kişi tüketiciler tarafından sunulan bilgilerin işlenmesi ve/veya korunması şeklinde bir yükümlülük altına girip girmediği hakkında karar verecektir. Ayrıca, kişisel verileri işleme ve/veya koruma yükümlülüğünün asli veya yan yükümlülük niteliğinde olup olmadığı, söz konusu yükümlülüğün ihlalinin aynı zamanda sözleşmenin ihlali sonucunu doğurup doğurmadığı meseleleri de bu hukuka tabi olacaktır. Bununla bağlantılı olarak, kişisel verileri işleme ve/veya koruma yükümlülüğ̈̈ne aykırı davranan satıcı/sağlayıcı vb. kişilere karşı tüketicinin maddi veya manevi tazminat talebinde bulunup bulunamayacağ 1 ve bunun şartlarının neler olduğu gibi hususların da MÖHUK m.26(1)-(2)'nin kapsamına girmektedir.

MÖHUK m.26(3) hükmünde ise, tüketici sözleşmelerinin esasına uygulanacak hukuka ilişkin yukarıdaki hükümlerden farklı olarak, tüketici sözleşmesinin şekline ilişkin özel bir kanunlar ihtilafı kuralı getirilmiştir. Buna göre, tüketici sözleşmesinin şekli geçerliliğinin tüketicinin mutad meskeni hukukuna tabi olacağı öngörülmüş ve böylece diğer taraf karşısında zayıf taraf konumunda olduğu varsayılan tüketicinin aşina olmadığ 1 hukuklara tabi k1lınarak istismar edilmesinin engellenmesi amaçlanmışıır ${ }^{54}$. MÖHUK m.26'nın son fikrasında ise, uygulanacak hukukun tespitine ilişkin değil, maddenin kapsamına giren tüketici sözleşmelerine ilişkin bir düzenlemeye yer verilmiştir. MÖHUK m.26'nın, paket tur sözleşmeler hariç olmak

\footnotetext{
${ }^{4}$ Bu konu hakkında ayrıntılı bilgi için bkz Toker (n 43) 45-46.
} 
üzere, taşıma sözleşmeleri ile tüketiciye hizmetin onun mutad meskeninin bulunduğu ülkeden başka bir ülkede sağlanması zorunlu olan sözleşmelere uygulanmayacağı belirtilmiştir.

\section{bb. Yetkili Hukukun Taraflarca Belirlenmesi (Hukuk Seçimi)}

MÖHUK m.26(1) hükmüyle Kanun Koyucu, yabanc1 unsurlu tüketici sözleşmelerine uygulanacak hukukun taraflarca serbestçe belirlenebileceğini öngörmüştür. Buna göre, tüketici sözleşmeleri, tüketicinin mutad meskeni hukukunun emredici hükümleri uyarınca sahip olacağı asgari koruma saklı kalmak kaydıyla, tarafların seçtikleri hukuka tabidir. Hukuk seçiminin ne şekilde yapılacağı konusunda MÖHUK m.26(1)'de herhangi bir açıklık yoktur. Ancak, MÖHUK m.26(1)'de düzenlenmese de, sözleşmelere uygulanacak hukuku gösteren genel hüküm niteliğindeki MÖHUK m.24'te yer alan hukuk seçimine ilişkin kuralların MÖHUK'daki sözleşmelere ilişkin özel kanunlar ihtilafı kuralları bakımından da uygulama alanı bulacağı kabul edilmektedir ${ }^{55}$. Dolayısıyla, ister MÖHUK m.26'nın kapsamına girsin ister girmesin, taraflar tüketici sözleşmesine uygulanacak hukuku MÖHUK m.24(1)-(3) hükümleriyle getirilen koşul ve sınırlamalar çerçevesinde serbetçe belirleyebilecektir. Bu bakımdan, aşağıda MÖHUK m.24(1)-(3) hükümleri için söyleyeceğimiz hususlar MÖHUK m.26'nın kapsamına giren tüketici sözleşmeleri bakımından da aynen geçerli olacaktı5 ${ }^{56}$.

MÖHUK m.26(1)'de tüketici sözleşmelerine uygulanacak hukukun taraflarca belirlenebileceği öngörülmekle birlikte, seçilen hukukun tüketici sözleşmesinden kaynaklanan uyuşmazlığa uygulanmasının, seçilen hukukun tüketicinin mutad meskeni hukukuna nazaran tüketiciye daha fazla koruma sağlanması halinde mümkün olduğu anlaşılmaktadır. Zira Kanun Koyucu, aynı zamanda MÖHUK m.26(2)'de objektif bağlama kuralı olarak da öngörülen tüketicinin mutad meskeni hukukunun sağladığı korumayı, MÖHUK m.26(1)'de düzenlenen hukuk seçimi açısından asgari düzey olarak belirlemiştir. Böylece, sözleşmenin diğer tarafına karşı daha zayıf konumda bulunduğu varsayılan tüketici aleyhine olabilecek bir hukuk seçiminin dayatılabileceği düşüncesiyle, tüketici sözleşmeleri bakımından sınırlı etkiye sahip bir hukuk seçimine imkân tanınmıştır ${ }^{57}$. Gerçekten, tüketicinin mutad meskeni hukuku, tüketicinin en iyi bildiği veya en azından aşina olduğu, bu sebeple tüketiciyi en iyi koruduğu kabul edilen hukuktur ${ }^{58}$. Dolayısıyla, hukuk seçiminin, tüketicinin mutad meskeninin bulunduğu ülke hukukunun tüketiciye sağladığı korumadan daha üst seviyede bir koruma sağlyyorsa, geçerli kabul edileceği belirtilmektedir. Buna karşın tüketicinin mutad meskeni hukukunun tüketiciye sağladığı koruma, seçilen hukuktan

\footnotetext{
Çalışkan (n 42) 41; Toker (n 43) 35; Şanl1, Esen ve Ataman-Figanmeşe (n 28$) 275$.

56 Tüketici sözleşmelerine uygulanacak hukukun hukuk seçimi yoluyla tespiti hakkında bkz Toker (n 43) 31-40.

57 Çelikel ve Erdem (n 28) 419; Toker (n 43) 32; Şanl, Esen ve Ataman-Figanmeșe (n 28) 300.

58 Çelikel ve Erdem (n 28) 419.
} 
daha üst seviyede ise hukuk seçimi geçerli olmayacaktır ${ }^{59}$. Şüphesiz ki, taraflarca seçilen devlet hukukunca da tüketicileri korumak üzere gerek kamusal gerekse özel hukuk karakterli bir takım emredici kurallara yer verilmiş olabilir. Zaten, taraflarca seçilen hukukun gerek emredici gerekse tamamlayıcı ve yorumlayıcı kurallarıyla birlikte, bir bütün olarak sözleşmeye uygulanması gerektiği kabul edilmektedir ${ }^{60}$.

Bununla birlikte, taraflarca seçilen hukukun hükümlerinin, tüketicinin mutad meskeni hukukunun emredici hükümlerinden farklı olduğu gerekçesiyle uygulanmaması yoluna gidilemeyeceği, hükümlerin birbirinden farklı olmasının önemli olmadığı da unutulmamalıdır. Bu noktada, hangi hükümlerin tüketicinin lehine olduğunun tespitinde, kural olarak sadece münferit hükümlerin karşılaştırılması gerekmektedir $^{61}$. Bir örnekle açıklamak gerekirse, tüketicinin mutad meskeni olan Türk hukukunda tüketiciye ait kişisel verilerin satıcı tarafından üçüncü kişiyle paylaşılması/pazarlanması bu konuda tüketicinin açık rızasına bağlıdır. Tüketici sözleşmesine uygulanmak üzere seçilen hukuk düzeninde tüketiciye ait kimlik ve iletişim bilgilerinin üçüncü kişilere paylaşımı için böyle bir şartın aranmaması halinde, yapılan veri işleme faaliyeti (veri aktarımı) hukuka aykırı olarak nitelendirilmeyecek, dolayısıyla satıcının kişisel verileri koruma yükümlülüğü söz konusu olmadığından tüketici sözleşmesine aykırılıktan bahsedilemeyecektir. Böyle bir durumda seçilen yabancı hukukun tüketicinin korunmasına ilişkin mevzuatta sözleşmeye aykırılık halinde tüketiciye -Türk hukukuna nazaran- daha fazla seçimlik hak tanımış olması, söz konusu hukukun tüketiciyi daha fazla koruduğu anlamına gelmeyecektir.

\section{cc. Hukuk Seçimi Yapılmayan Hallerde Sözleşmeye Uygulanacak Hukukun Tespiti (Objektif Bağlama Kuralı)}

Tarafların hukuk seçimi yapmamış olmaları halinde, tüketicinin mutad meskeninin bulunduğu ülke hukuku sözleşmeden doğan uyuşmazlığa uygulanacaktır (MÖHUK m.26(2)). Bununla birlikte, tüketicinin mutad meskeni hukukun uygulanabilmesi için maddede bazı şartlar getirilmiş ve bu şartlardan en az birinin gerçekleşmiş olması halinde tüketicinin mutad meskeni hukukunun uygulanacağı öngörülmüştür. MÖHUK m.26(2) uyarınca tüketicinin mutad meskeni hukukunun uygulanabilmesi için aranan şartlar şunlardır:

\footnotetext{
59 Nomer (n 28) 351; Çelikel ve Erdem (n 28) 419; Güngör Gülin, 'Tüketicinin Mutad Meskeni Hukuku-Düşünsel Temeller' (2008) 57(2) AÜHFD 115, 124-125; Tarman, Tüketici (n 47) 339.

60 Güngör (n 59) 127.

${ }_{61}$ Nomer (n 28) 351; Toker (n 43) 33.
} 
a) Tüketici sözleşmesinin tüketicinin mutad meskeninin bulunduğu ülkede, ona gönderilen özel bir davet üzerine veya ilan sonucunda kurulmuş ve sözleşmenin kurulması için tüketici tarafından yapılması gereken hukuki fiiller bu ülkede yapılmış olmalidir ${ }^{62}$ veya

b) Tüketici sözleşmesinin diğer tarafı veya temsilcisi, tüketicinin siparişini tüketicinin mutad meskeninin bulunduğu ülkede almalıdır ${ }^{63}$ veya

c) Taraflar arasındaki ilişkinin bir satım sözleşmesi olması halinde, satıcı tüketiciyi ikna etmek üzere bir gezi düzenlemiş ve tüketici de bu gezi ile bulunduğu ülkeden başka bir ülkeye gidip siparişini orada vermiş olmalıdır.

Görüldüğü üzere, yabancılık unsuru içeren her türlü tüketici sözleşmeleri MÖHUK m.26(2)'nin kapsamına girmemektedir. Buna göre, tüketici sözleşmesi ya satıcının tüketiciye (pasif tüketiciye) yönelmesi neticesinde tüketicinin yaşadığı sosyal ve hukuki çevre içerisinde kurulmuş olmalı (home deal) ya da tüketicinin (aktif tüketici) sözleşmenin karşı tarafinın düzenlemiş olduğu bir geziye katıldığı ve bu gezi ile sözleşme yapmak üzere götürüldüğü ülkede kurulmuş (traveller's deal) olmalıdır. Böylece, tüketicinin yaşadığı yerin standartları ile korunması amaçlanmış ve bu amacı gerçekleştirmek açısından en uygun bağlama noktasının tüketicinin mutad meskeni olduğu sonucuna varılmıştır ${ }^{64}$. Bu bakımdan, MÖHUK m.26 ile her türlü tüketici sözleşmelerinin değil, sadece milletlerarası özel hukukun koruma amacına giren tüketicilerin korunmasının hedeflendiğini, diğer tüketici sözleşmeleri bakımından tüketicinin kendi mutad meskeni hukukunca korunmasına gerek duyulmadığını söylemek mümkündür ${ }^{65}$.

Sonuç olarak, tüketici sözleşmesinin kurulması veya ifasılyla ilgili olarak elde edilen gerçek kişi tüketiciye ait kişisel verilerin hukuka aykırı olarak işlenmesi veya bunların korunmaması nedeniyle ileri sürülecek tüketici sözleşmelerine aykırılık iddialarının tüketicinin mutad meskeni hukukuna göre karara bağlanabilmesi için sözleşmenin yukarıda üç koşuldan/özellikten birine sahip olması gerekmektedir. Örneğin, mutad meskeni yabancı ülkede olan bir kişiyle Türkiye'de saç ekimi

\footnotetext{
62 Örneğin, üretici veya satıcı basın, radyo veya televizyon gibi medya yoluyla veya katalog dağıtım yoluyla ürünün reklamını tüketicinin mutad meskeninin bulunduğu ülkede yapmışsa ve tüketici de sözleşmenin kurulması için gerekli hukuki fiilleri bu ülkede yapmışsa, tüketici sözleşmesi MÖHUK m.26(2)(a) kapsamına girecektir. Örnek için bkz Toker (n 43) 42-43. $\mathrm{Bu}$ bendin kapsamına, posta yoluyla siparişler ile kapıdan yapılan satışların da girdiği hakkında bkz Nuray Ekşi, 'Avrupa Birliği Konvansiyonuna Göre Tüketici Sözleşmelerine Uygulanacak Hukuk’ (2004) 3(1-2) İKÜHFD 139; Elektronik ortamda düzenlenen tüketici sözleşmelerinin de bu bent kapsamına girdiğine dair bkz Hatice Özdemir Kocasakal, Elektronik Sözleşmelerden Doğan Uyuşmazlıkların Çözümüne Uygulanacak Hukukun ve Yetkili Mahkemenin Tespiti (Vedat 2003) 136ff; Gamze Turan, 'Elektronik Sözleşmeler ve Elektronik Sözleşmelere Uygulanacak Hukukun Tespiti' (2008) 77 Türkiye Barolar Birliği Dergisi 87, 112ff; Pürselim (n 53) 89.

63 Satıcı veya temsilcisinin fuar veya sergi amacıyla tüketicinin mutad meskeninin bulunduğu ülkeye gelmesi ve tüketicinin siparişini bu ülkede alması suretiyle gerçekleşen bir tüketic sözleşmesi MÖHUK m.26(2)(b) kapsamına girmektedir. Ancak, bu bendin uygulama alanı bulabilmesi için tüketici sözleșmesinin kurulmuş olması şartı aranmamaktadır. Bkz Günseli Öztekin Gelgel, Milletlerarası Özel Hukukta Tüketici Akitlerine Illişkin Sorunlar, (Beta 2004) 65; Tarman, Tüketici (n 47) 337.

64 Güngör (n 59) 119; Şanl1, Esen ve Ataman-Figanmeșe (n 28) 301; Toker (n 43 ) 42.

65 Güngör (n 59) 119; Şanl, Esen ve Ataman-Figanmeşe (n 28) 301; Toker (n 43 ) 42.
} 
tedavisi veya estetik ameliyat hizmeti sunan bir tıp merkezi arasında ve bu kişinin tıp merkezinin yapmış olduğu teklifi kabul etmesi suretiyle tüketicinin mutad meskeninin bulunduğu ülke akdedilen tedavi veya ameliyat sözleşmesi, MÖHUK m.26(2)(a) kapsamına girmektedir. Sözleşme kapsamına saç ekimi tedavisi alan veya estetik operasyon geçiren bu gerçek kişinin tedavi öncesi ve sonrası fotoğraflarının tıp merkezince reklam amacıyla yayınlanması halinde, söz konusu kişi, kişisel verilerinin rızası olmaksızın kullanıldığı gerekçesiyle sözleşmenin ihlal edildiğini ileri sürebilir. Bu durumda, kural olarak sözleşmeye aykırılığın var olup olmadığı tüketicinin mutad meskeni hukuku uyarınca karara bağlanacaktır.

MÖHUK m.26(2)'deki şartların hiçbirinin gerçekleşmemiş olması halinde, söz konusu tüketici sözleşmesine uygulanacak hukuk MÖHUK m.24 uyarınca belirlenecektir ${ }^{66}$. Başka bir ifadeyle, milletlerarası özel hukukun koruma amacına girmeyen tüketici sözleşmelerinin yukarıdaki gerekçelerle ihlal edildiği iddiaları bakımından ise MÖHUK m.24 hükmü uygulanacaktır.

\section{d. MÖHUK m.26 Kapsamına Girmeyen Tüketici Sözleşmelerine Uygulanacak Hukukun Tespiti}

Gerek MÖHUK m.26(1)'deki tanım gerekse TKHK hükümleri dikkate alındığında tüketici sözleşmesi niteliğinde olmasına rağmen, Kanun Koyucu tarafından MÖHUK m.26'nın kapsamı dışında tutulan kimi tüketici sözleşmeleri de bulunmaktadır. Taşıma sözleşmeleri ile tüketiciye hizmetin onun mutad meskeninin bulunduğu ülkeden başka bir ülkede sağlanması zorunlu olan tüketici sözleşmelerinden doğan uyuşmazlıkla bakımından MÖHUK m.26(1)-(2) hükümlerinin uygulanmayacağı MÖHUK m.26(4) hükmü ile ortaya konmuştur. Bununla birlikte, taşıma ve konaklama gibi turistik hizmetlerin birlikte taahhüt edildiği ve tek fiyat uygulamasının olduğu gezilere ilişkin sözleşmeler, yani paket tur sözleşmeler ${ }^{67}$ hakkında MÖHUK m.26 hükmünün uygulanacağı MÖHUK m.26(4)'te açıkça düzenlenmiştir ${ }^{68}$. Buna göre, bir işletmenin sadece konaklama veya ulaşım hizmeti sunmayı taahhüt ettiği tüketici sözleşmeleri MÖHUK m.26'nın kapsamına girmemektedir ${ }^{69}$.

MÖHUK m.26(4) uyarınca kapsam dışında tutulan taşıma sözleşmeleri, mesleki veya ticari olmayan amaçlarla yapılmak kaydıyla, esasen birer tüketici sözleşmesi

${ }_{66}$ Çelikel ve Erdem (n 28) 420; Şanl, Esen ve Ataman-Figanmeşe (n 28) 300; Toker (n 43) 41.

${ }^{67}$ Paket tur sözleşme ile neyin anlaşılması gerektiği de bir vasıflandırma meselesi olarak Türk mahkemelerinin önüne gelebilir. Paket tur sözleşmeleri TKHK m.51'de tanımlanmıştır. Buna göre, ulaştırma, konaklama veya bunlara bağlı olmayan başka turizm hizmetlerinden en az ikisini içeren ve hizmetin yirmi dört saatten fazla bir süreyi kapsadığı veya gecelik konaklamayı içerdiği sözleşmeler, paket tur sözleşmesi olarak nitelendirilmektedir.

68 Şanl, Esen ve Ataman-Figanmeşe (n 28) 302; Toker (n 43) 30; Tarman, Tüketici (n 47) 331-332.

${ }^{69}$ MÖHUK m.26'nın gerekçesinde, bir yandan Türkiye'nin tarafı olduğu çok sayıda milletlerarası anlaşma ile düzenlenmiş olması diğer yandan eşya taşınmasına ilişkin sözleşmeler bakımından MÖHUK m.29'da özel bir düzenlemeye yer verilmiş olması nedeniyle taşıma sözleşmelerinin maddenin kapsamı dışında tutulduğu belirtilmektedir. Madde gerekçesi için bkz Öztekin Gelgel ve Erdem (n 42) 93. 
niteliğindedir. Örneğin, bir kargo veya nakliye firması tarafından bir kişiye ait eşyaların taşınmasının veya bir havayolu firması tarafindan bir gerçek kişinin taşınmasının taahhüt edildiği sözleşmeler tüketici sözleşmesi niteliğindedir. Bunlardan, eşyaların taşınmasının taahhüt edildiği yabancı unsurlu sözleşmeler bakımından MÖHUK m.29'da özel bir kanunlar ihtilafı kuralına yer verilmiştir. MÖHUK m.29 hükmünde, eşyanın taşınmasına ilişkin sözleşmenin ticari veya tüketici işlemi niteliğinde olmas1 şeklinde bir koşul veya sınırlama getirilmediği de göz önüne alındığında, konusunu eşyanın taşınmasının oluşturduğu yabancı unsurlu tüketici sözleşmelerinden kaynaklanan uyuşmazlıklara uygulanacak hukuk MÖHUK m.29 hükümleri uyarınca tespit edilecektir.

Kişilerin taşınmasını konu edinen yabancı unsurlu sözleşmelerden doğan uyuşmazlıklara uygulanacak hukuku gösteren özel bir kanunlar ihtilafı kuralına MÖHUK' da yer verilmemiştir. Keza, tüketiciye hizmetin onun mutad meskeninin bulunduğu ülkeden başka bir ülkede sağlanmasının zorunlu olduğu tüketici sözleşmelerine ilişkin bir hüküm de bulunmamaktadır. $\mathrm{Bu}$ nedenle, kişilerin taşınmasına ilişkin veya tüketiciye hizmetin onun mutad meskeninin bulunduğu ülkeden başka bir ülkede sağlanmasının zorunlu olduğu tüketici sözleşmelerinden kaynaklanan uyuşmazlıklara uygulanacak hukuk sözleşmelere ilişkin genel kural mahiyetindeki MÖHUK m.24 uyarınca tespit edilecektir ${ }^{70}$.

Bunların yanı sıra, hatırlanacağı üzere hukuk seçiminin yapılmamış olması halinde, tüketicinin mutad meskeninin hukukunun uygulanacağı öngören MÖHUK m.26(2)'de tüketicinin mutad meskeni hukukunun uygulanabilmesi, tüketici sözleşmesinin MÖHUK m.26(2)(a)-(c)'de yer alan üç koşuldan birini karşılamasına bağlanmıştır. İşte bu üç koşuldan en az birini karşılamayan, başka bir ifadeyle MÖHUK m.26(2)'de tarif edilen özelliklere sahip olmayan yabanc1 unsurlu tüketici sözleşmelerinden doğan uyuşmazlık tüketicinin mutad meskeni hukukuna göre karara bağlan(a)mayacaktır. Dolayısıyla, bu üç koşuldan en az birini karşılamadığından milletlerarası özel hukukun koruma amacına girmeyen tüketici sözleşmelerine uygulanacak hukuk, MÖHUK m.24 uyarınca tespit edilecektir ${ }^{71}$. Biz bu başlık altında, sadece konusunu eşya taşımalarının oluşturduğu tüketici sözleşmelerine uygulanacak hukukun MÖHUK m.29 uyarınca nasıl tespit edileceği meselesini ele alacağız. Aşağıda kişisel verilerin işlenmesi veya korunmaması suretiyle gerçekleşen sözleşmesel sorumluluğa uygulanacak hukuku gösteren genel hüküm niteliğindeki MÖHUK m.24 hükmünü ayrıca ele alacağız. Bu bakımdan, MÖHUK m.24'e ilişkin aşağıda yapacağımız açıklamalar, gereksiz tekrara düşmemek adına, MÖHUK m.26'nın ve m.29'un kapsamına girmeyen tüketici sözleşmelerine uygulanacak hukukun tespiti bakımından da geçerlidir ${ }^{72}$.

\footnotetext{
Çelikel ve Erdem (n 28) 451; Şanl, Esen ve Ataman-Figanmeşe (n 28) 302, 309; Toker (n 43) 30 Çelikel ve Erdem (n 28) 420; Şanl, Esen ve Ataman-Figanmeşe (n 28) 300; Toker (n 43) 41.

Bkz Aşağıda III/ D/ 2.
} 
Yabancılık unsuru içeren ve aynı zamanda tüketici sözleşmesi niteliğinde olan bir eşya taşıma sözleşmeleri ile kişisel verilerin işlenmesi arasında ne tür bir ilişkinin olabileceği konusunda ilk bakışta bir tereddüt yaşanabilir. Dolayısıyla, kişisel verilerin hukuka aykırı olarak işlenmesinin veya korunmamasının yabancı unsurlu eşya taşıma sözleşmesine aykırılık teşkil etme ihtimalinin nadiren ortaya çıkacağı veya hiç ortaya çıkmayabileceği de söylenebilir. Bununla birlikte, eşyanın taşınmasını taahhüt eden taşıyıcının (örneğin bir nakliye şirketinin veya denizcilik firmasının) sözleşmenin kurulması veya taşımanın yapılabilmesi (ifası) amacıyla tüketiciye/taşıtana ait kimi bilgileri (örneğin kimlik, hesap ve iletişim bilgileri) işlemesi (kaydetmesi, depolaması) ve bunları koruması gerekebilecektir. Bu bakımdan, niteliği itibariyle bir tüketici sözleşmesi olsa da, taşıyıcının tüketiciye/taşıtana ait kişisel verileri işleme/koruma yükümlülüğü altında olup olmadığı, böyle bir yükümlülüğün yerine getirilmemesinin sözleşmeye aykırılık teşkil edip etmediği veya hangi hallerde teşkil edeceği gibi pek çok husus hakkında MÖHUK m.29 hükmü uygulama alanı bulacaktır ${ }^{73}$. Kısacası, Kanun koyucu tarafindan milletlerarası özel hukukun koruma amacına girmediği varsayılan eşya taşımaya ilişkin tüketici sözleşmelerinden doğan uyuşmazlıklar hakkında m.29 uyarınca yetkili kılınan hukuk karar verecektir ${ }^{74}$.

MÖHUK m.29(1)'de eşyanın taşınmasına ilişkin sözleşmeler tarafların seçtikleri hukuka tabi k1lınmıştır ${ }^{75}$. Görüldüğü üzere, MÖHUK m.26(1)'den farklı olarak, konusunu eşya taşımanın oluşturduğu tüketici sözleşmeleri bakımından tüketicilere herhangi bir koruma sağlanmamıştır. Diğer yandan, tıpkı MÖHUK m.26(1)'de olduğu gibi, hukuk seçiminin ne şekilde yapılacağı konusunda madde metninde bir açıklık yoktur. Dolayısıyla, genel hüküm niteliğindeki MÖHUK m.24'te yer alan hukuk seçimine ilişkin kurallar, MÖHUK'da yer alan her türlü sözleşme bakımından da uygulama alanı bulacağından, hukuk seçimine ilişkin MÖHUK m.24(1)-(3)'de getirilen koşul ve sınırlamaların eşya taşınmasına ilişkin tüketici sözleşmeleri bakımından da geçerli olduğunu söylemek mümkündür ${ }^{76}$.

Tarafların hukuk seçimi yapmamış olmaları halinde eşya taşıma sözleşmesine MÖHUK m.29(2) uyarınca sözleşmenin kuruluşu sırasındaki taşıyıcının esas işyerinin

\footnotetext{
3 Bu noktada, Türkiye'nin tarafı olduğu ve konusunu eşyaların taşınmasını oluşturan pek çok uluslararası anlaşmanın bulunduğunu, bu anlaşmalarda taşıma sözleşmelerinden doğan sorumluluğa ilişkin maddi hukuk kurallarına yer verildiğ unutulmamalıdır. Dolayısıyla, MÖHUK m.29 hükmü, bir uluslararası anlaşmanın kapsamına girmekle birlikte, söz konusu anlaşmada maddi hukuk kurallarıyla düzenlenmeyen konular bakımından uygulama alanı bulacaktır.

74 Taşımanın ne şekilde yapıldığı, hükmün uygulanması bakımından önem arz etmemekte olup, deniz, hava, demir veya karayoluyla yapılan her türlü yabancı unsurlu taşıma sözleşmesi hükmün kapsamına girmektedir. Bkz Şanlı, Esen ve Ataman-Figanmeșe (n 28) 309

75 Çelikel ve Erdem (n 28) 450; Şanlı, Esen ve Ataman-Figanmeşe (n 28) 309; Nuray Ekşi, 'Uluslararası Eşya Taşıma Sözleşmelerine Uygulanacak Hukuk (5718 Sayılı MÖHUK md. 29)' Koç Üniversitesi Hukuk Fakültesi Dr. Nüsret-Semahat Arsel Uluslararası Ticaret Hukuku Uygulama ve Araştırma Merkezi Konferans Yayınları Dizisi-2: Avrupa'da Devletler Özel Hukuku ve Yeni Türk Milletlerarası Özel Hukuk ve Usul Hukuku Hakkında Kanun'un Akitler ve Ticaret Hukukuna İlişkin Hükümleri (Legal 2010) 125, 126; Rumeysa Partalcı, 'Eşyanın Taşınmasına İlişsin Sözleşmelere Uygulanacak Hukuk Hakkındaki MÖHHK Madde 29'un Değerlendirilmesi' (2017) 37(2) MHB (Prof. Dr. Yücel Sayman'a Armağan) 945, 962.

76 Partalc1 (n 75) 962.
} 
bulunduğu ülke hukuku uygulanacaktır. Ancak, taşıyıcının esas işyeri hukuku, ancak belirli şartların gerçekleşmesi halinde uygulama alanı bulabilecektir. Buna göre, taşıyıcının esas işyeri hukukunun uygulanabilmesi için ya malların yükleme veya boşaltma yeri ya da gönderenin esas işyeri taşıyıcının esas işyerinin bulunduğu ülke ile aynı olmalıdır ${ }^{77}$. Örneğin, Türkiye'den satın alınan bir miktar mobilyanın Bulgaristan'a taşınması konusunda Bulgar tüketici ile merkezi Türkiye'de bulunan nakliye şirketi arasında yapılan bir sözleşmeye nakliye şirketinin esas işyeri (Türk) hukukunun uygulanabilmesi için, mobilyanın yüklendiği ülkenin Türkiye olması yeterli olacaktır. Gönderenin menfaatinin de gözetilmesi amacıyla getirildiği belirtilen ${ }^{78}$ bu şartlar dikkate alındığında, hükmün esasen ticari karakterli eşya taşıma sözleşmeler bakımından uygulanacağı düşüncesiyle kaleme alındığını söylemek mümkündür.

MÖHUK m.29(3)'de MÖHUK m. 29(2)'deki kanunlar ihtilafı kuralını devre dışı bırakan bir kurala yer verilmiş ve halin bütün şartlarına göre eşyanın taşınmasına ilişkin sözleşme ile daha sıkı ilişkili bir hukukun bulunması halinde sözleşmeye bu hukukun uygulanacağı öngörülmüştür. Doktrinde istisna kuralı olarak nitelendirilen ${ }^{79}$ bu hüküm uyarınca, MÖHUK m.29(2)'de yer alan şartları karşılasa dahi, eşya taşıma sözleşmesinin taşıyıcının esas işyeri hukukuna nazaran daha sıkı ilişkili olduğu bir ülke hukukunun araştırılması gerekecektir.

Taşıyıcının esas işyeri hukukunun uygulanabilmesi için MÖHUK m.29(2)'deki şartların gerçekleşmemesi durumunda nasıl bir yol izlemesi gerektiği konusunda MÖHUK m.29'da bir açıklık bulunmamaktadır. Ancak, maddenin gerekçesinden taşıyıcının işyeri hukukunun uygulanabilmesi için aranan şartların yokluğu halinde MÖHUK m.24'deki genel kuralın uygulanacağı anlaşılmaktadır ${ }^{80}$. Nitekim doktrinde, taşıyıcının esas işyeri hukukunun uygulanması için gereken şartların gerçekleşmemesi halinde, eşyanın taşınmasına ilişkin sözleşmeye uygulanacak hukukun MÖHUK m. 24(4)'deki objektif bağlama kuralı uyarınca belirlenmesi gerektiği savunulmaktadır ${ }^{81}$.

\footnotetext{
Doktrinde, fiilen yükleme veya boşaltma yapılan yerlerin MÖHUK m.29 bakımından bir öneminin olmadığı belirtilerek, yükleme ve boşaltma limanlarının taşıma sözleşmesinde yer alan limanlar olduğu savunulmaktadır bkz Ekşi, $m .29$ (n 75 ) 127.

78 Şanlı, Esen ve Ataman-Figanmeşe (n 28) 310; Tekinalp ve Uyanık-Çavuşoğlu (n 28) 432.

79 Çelikel ve Erdem (n 28) 398, 451; Tekinalp ve Uyanık-Çavuşoğlu (n 28) 433.

80 Bkz Öztekin Gelgel ve Erdem (n 42) 100.

81 Çelikel ve Erdem (n 28) 451; Tekinalp ve Uyanık-Çavuşoğlu (n 28) 432; Aybay ve Dardağan (n 28) 269. Bu görüşe göre, eşya taşınmasına ilişkin tüketici sözleșmesine MÖHUK m.24(4) uyarınca sözleşmeyle en sıkı ilişkili hukuk uygulanacaktır En sıkı ilişkili hukukun tespitinde MÖHUK m.24(4)'de yer alan karineler uyarınca ticari veya mesleki faaliyet gereği kurulan sözleşmelerde karakteristik edim borçlusunun işyeri veya yerleşim yeri hukuku, sözleşme ticari veya mesleki faaliyet gereği kurulmayan bir sözleşme söz konusu ise karakteristik edim borçlusunun işyeri hukuku, en sıkı ilişkili hukuk olacaktır. İster ticari veya mesleki faaliyet gereği kurulmuş olsun isterse olmasın, karakteristik edim kavramına ilişkin tanımlar dikkate alındığında eşya taşıma sözleşmelerinde karakteristik edim borçlusunun taşıyıcı olduğu sonucuna varmak mümkündür. Eşya taşıma sözleşmeleri bakımından karakteristik edim borçlusu olan taşıyıcının sözleşmenin kuruluşu sırasındaki mutad meskeni veya yerleşim yeri/işyeri ya da sözleşmeyle en sıkı ilişkili işyeri hangi ülkede ise, sözleşmeyle en sıkı ilişkili hukuk da bu ülke hukuku olacaktır. Bu açıklamalarımız, aynı zamanda eşya taşıma sözleşmeleri bakımından taşıyıcının ediminin Kanun Koyucu tarafından karakteristik edim olarak bizzat tespit edilmiș olduğu görüșünü (Bkz Şanll, Esen ve Ataman-Figanmeșe (n 28) 310) teyit eder niteliktedir. Bu itibarla, MÖHUK m.24(4) hükmü tatbik edildiğinde, MÖHUK m.29(2)'de yer alan şartları karşılasın veya karşılamasının, taşıyıcının mutad meskeni/yerleşim yeri/işyeri veya sözleşmeyle en sıkı ilişkili işyeri hukukunun eşya taşımalarına ilişkin tüketici sözleşmeleri bakımından uygulama alanı bulacağını söyleyebiliriz.
} 
Buna mukabil, MÖHUK m.29(2)'nin aksi ispat edilebilen bir karine getirdiği, bu karine uyarınca en sıkı ilişki hukuk olarak taşıyıcının esas işyeri hukukunun öngörüldüğü, MÖHUK m.29(2)'deki şartların gerçekleşmemesi halinde de karinenin çürütülmüş olacağ 1 ve MÖHUK m.29(3) hükmü uygulanarak sözleşmeyle en sık1 ilişkili hukukun hal ve şartlara göre tespit edilmesi gerektiği de savunulmaktadır ${ }^{82}$. Buna göre, somut olayın özelliklerine göre eşya taşıma sözleşmesiyle en sıkı ilişkili olduğu tespit edilen hukuk, sözleşmeden kaynaklanan uyuşmazlığa uygulanacaktır.

Esasen, MÖHUK m.29(3) hükmü, MÖHUK m.24(4)'ün son cümlesinde yer alan ve her hâlükârda sözleşmeyle daha sıkı ilişkili hukukun var olup olmadığını araştırma yükümlülügü getiren istisna kuralının tekrarı mahiyetindedir. Bu itibarla, gerek MÖHUK m.29(2)'deki koşulları karşılayan gerekse karşılamayan eşya taşıma sözleşmeleri bakımından, eşya taşıma sözleşmesiyle daha sıkı ilişkili hukukun varlığı halinde bu hukuk sözleşmeye uygulanacaktır. Başka bir ifadeyle, MÖHUK m.29(2)'deki şartların yokluğu halinde MÖHUK m.24(4) uyarınca tespit edilen en sıkı ilişkili hukuk (taşıyıcının mutad meskeni/yerleşim yeri/işyeri veya sözleşmeyle en sıkı irtibatl işyeri hukuku) ile MÖHUK m.29(2) uyarınca tespit edilen taşıyıcının esas işyerinin bulunduğu ülke hukukuna nazaran sözleşmeyle daha sıkı irtibatlı hukukun varlığı yine benzer şekilde araştırılıp tespit edilecektir ${ }^{83}$. Bu nedenle, taşıyıcının esas işyeri hukuku ile eşya taşıma sözleşmesiyle en sıkı ilişkili hukukun birbiriyle örtüşmediği haller bakımından, MÖHUK m.24(4)'un uygulanması ile MÖHUK m.29(3)'un uygulanması arasında bir farklılığın bulunmadığı kanaatindeyiz.

\section{Kişisel Verilerin Yabancı Unsurlu İş Sözleşmelerine Aykırı Olarak İşlenmesi veya Korunmaması Halinde Uygulanacak Hukukun Tespiti}

\section{Kişisel Verilerin İşlenmesi veya Korunması ile İş Sözleşmeleri Arasındaki İlişski}

Kişisel verilerin işlenmesi faaliyetinin bir sözleşme ilişkisi çerçvesinde meydana geldiği sözleşme türlerinden bir diğeri de iş sözleşmeleridir. İş sözleşmesinin kurulmasıyla veya işin ifasıyla ilgili olarak işlenmesi gereken kişisel veriler, tüketici sözleşmelerinden farklı olarak çok çeşitlidir ve bunların çoğu, aynı zamanda tarafların sözleşmeden kaynaklanan borçlarının ifasıyla oldukça yakından alakalıdır. Bunların ilk başında, iş görüşmeleri esnasında adaydan talep edilen kimi bilgi ve belgeler gelmektedir. Zira işverenin işe elverişli olup olmadığını belirlemek amacıyla istihdam edeceği kişiye bir takım soruları yönelterek bilgi edinme hakkı bulunmaktadır. Adayın da söz konusu soruları kişisel verilerin korunması hakkını

\footnotetext{
Şanlı, Esen ve Ataman-Figanmeşe (n 28) 310; Ekşi, m.29 (n 75)126. Benzer yönde bkz Partalcı (n 75 ) 967.

83 Eşya taşıma sözleşmelerinde daha sıkı ilişkili hukukun ne şekilde tespit edileceği ve bu amaçla dikkate alınabilecek unsurların neler olduğu hakkında bkz Partalcı (n 75) 963.
} 
ihlal etmediği sürece cevaplama, işin ifasını zorlaştıracak veya imkânsız hale getirecek bilgileri açıklama yükümlülügüüü yerine getirmesi gerekmektedir ${ }^{84}$. Bu bağlamda, sözleşme öncesi görüşmeler esnasında işveren tarafından adaya sorular veya testler yöneltilebilir, özgeçmiş, sınav evrakı, diploma, sertifika, sağlık raporu gibi kimi belgeler talep edilebilir. Yine, adaya işin niteliği ve ifasıyla ilgili olmak kaydıyla, mesleki tecrübesi, yabancı dil bilgisi, askerlik durumuna ilişkin kişisel sorular yöneltilmesi mümkündür ${ }^{85}$. İşçinin medeni durumuna ve çocuk sayısına ilişkin bilgiler ile eğitim seviyesine ilişkin bilgiler ise, işverenin toplu iş sözleşmelerinden kaynaklanan parasal yükümlülükleri açısından veya seyahat etmeyi gerektiren işler bakımından belirleyici olabilir ${ }^{86}$. Keza, işveren iş sözleşmesi kurulduktan sonra ücret ödeyebilmek veya sigorta kaydını yapabilmek gibi yasal işlemler amacıyla işçinin kimlik ve banka hesap bilgileri isteyebilir.

İşveren, özel uzmanlık gerektiren alanlarda istihdam edilmek üzere adayın üyelik veya sertifika gibi işçinin mesleki eğitimi veya uzmanlığına ilişkin bir takım kişisel verileri işlemek durumunda kalabilir ${ }^{87}$. Mesela, bir doktorun mesleki deneyimini ve sahip olduğu yetkiliğini ortaya koyan bilgiler, bir özel hastane tarafından sadece istihdam edilmesi için gerekli olabileceği kadar, hastanenin kendi reklamını yapabilmek amacıyla doktora ait bu bilgileri kullanması söz konusu olabilir. İşçinin sağlık durumuna ilişkin bilgiler de, iş sözleşmesinin kurulması veya ifasıyla doğrudan ilgili olabilen, hatta yasal zorunluluk gereği edinilmesi gereken bilgiler arasındadır ${ }^{88}$. Adaya ve işçiye ait kişisel sağlık verileri, özel nitelikli (hassas) veri niteliğinde olup, gerek işe alım sürecinde gerekse sonrasında işverenle paylaşılması ve işverenin söz konusu sağlık verilerini saklaması/koruması özel bir önem arz etmektedir ${ }^{89}$. $\mathrm{Bu}$ kapsamda, işçinin tedavi edilemeyecek nitelikte olan ve çalışma yeteneğini sınırlandıran veya ortadan kaldıran bir hastalığı olması, sağlık sebeplerine dayanan bir haklı fesih nedeni olduğu için, işçinin sağlık durumuna ilişkin bilgileri işverenle paylaşması gerekmektedir ${ }^{90}$.

Adayın ve işçinin sağlık durumunun yanı sıra, hamileliğine yönelik bilgiler de kişisel veri niteliğindedir ve ancak işin niteliği gereği (hamilelerin çalışmasının yasak olduğu hallerde), işvereninin bu konuda bilgilendirilmesi gerekmektedir. Hatta bu durum işverenin işçiyi gözetme ve koruma borcunu yerine getirebilmesi

\footnotetext{
Selen Uncular, İ̧̧ İş̧isisinde İşçinin Kişisel Verilerinin Korunması (2.Bası, Seçkin 2018) 188-189.

85 Gürsel (n 31) 294; Uncular (n 84) 189.

86 Gürsel (n 31) 292; Uncular (n 84) 190-192.

87 Gürsel (n 31) 294.

88 Gürsel (n 31) 300ff

89 Uncular (n 84) 197; Gürsel (n 31) 301-302.

90 Örneğin, hemşirelik, doktorluk, laboratuar teknisyenliği gibi iş türlerine başvuranların AIDS hastası olma durumunu veya yakın gelecekte ameliyat gibi iş görmeyi engelleyecek türden tedavilerin varlığını işverene bildirmeleri gerekmektedir. Bkz Gürsel (n 31) 301. Bununla birlikte, ișin niteliğiyle ilgili olmayan veya ileride tekrar ortaya çıkma ihtimali bulunmayan hastalık veya engellilik durumunun olup olmadığı sorulamayacağı gibi, adayın ve işçinin bu sorulara doğru cevap verme yükümlülüğü bulunmamaktadır. Bkz Gürsel (n 31) 301.
} 
için bir gereklilik olarak ortaya çıkmaktadır ${ }^{91}$. Benzer şekilde, engellilik durumu da bir kişisel veri niteliğindedir ve engellilerin istihdamı konusunda işverenlere getirilen yasal yükümlülüklerin yerine getirilebilmesi ve bu yükümlülükleri ifa edip etmediğinin denetimi için adayın veya işçinin engellilik durumu hakkında bilgi edinmesi kaçınılmazdır ${ }^{92}$. Bunların yanı sıra adayın ve işçinin ceza mahkûmiyetine ilişkin bilgiler de kişisel veri niteliğindedir ve işin niteliği bakımından önemli olmak kaydıyla adaya bu konuda sorular sorulabilir. Ayrıca, bu bilgiler aynı zamanda hassas veri niteliğindedir. Örneğin, banka veznedarına bir mali suç işleyip işlemediği veya bir doktora yanlış teşhis ve tedavi nedeniyle cezai mahkûmiyetinin olup olmadığına ilişkin soru yöneltilebilir ve adayın/işçinin de işvereni bu konuda bilgilendirmesi gerekmektedir $^{93}$. Adaya ve işçiye yöneltilen dini veya felsefi inanca, siyasi görüşe, parti ve sendika üyeliğine ilişkin bilgiler hassas veri niteliğindedir ve bu bilgilerinin edinilmesi amacıyla işveren tarafından soru sorulması, belirli istisnalar ve meşru nedenler dışında, geçerli ve hukuka uygun değildir ${ }^{94}$.

Görüldüğü üzere, yukarıda örnek kabilinden saydığımız kişisel verilerin pek çoğu, iş sözleşmesinin kurulabilmesi ve/veya istihdam edilen/edilecek şahsın çalışma yeteneğinin işveren tarafindan tespit edilebilmesini sağlaması itibariyle oldukça önem arz etmektedir. Zira söz konusu kişisel veriler, işverenin iş ilişkisinin kurulması veya devamına yönelik kararını etkileyebilecek niteliktedir. Yukarıdaki açıklamalarımızdan anlaşılacağı üzere, iş sözleşmesinin kurulabilmesi veya işçinin veya işverenin sözleşmeden doğan edimlerini yerine getirebilmeleri için işverenin işçiye ait kişisel verileri hukuka uygun bir şekilde edinmesi, kullanması ve iş iliş̧isinin devam süresince ve iş ilişkisi sona erdikten sonra da saklaması gerekmektedir ${ }^{95}$. Hatta sözleşme kurulmamış olsa dahi, iş̧̧i adayının iş sözleşmesinin kurulması amacıyla sunmuş olduğu kişisel verilerin saklanması gerekmektedir ${ }^{96}$. Bu noktada işçiye ait her türlü kişisel verinin değil, sözleşmenin ifası bakımından gerçekten gerekli olan verilerin işveren tarafından işlenmesi gerekmektedir ${ }^{97}$. İşin niteliğiyle veya ifasıyla ilgili olmayan kişisel verileri işlenmesi hukuka aykırı olduğu gibi, işçinin işvereni bu konular hakkında bilgilendirme yükümlülüğü de bulunmamaktadır.

$\mathrm{Bu}$ bakımdan, aday veya işçi hakkında işverence bilgi toplanırken işletilmesi gereken temel kuralın elde edilmek istenen bilgi ile işin niteliğinin bağlantılı olması olduğunu söyleyebiliriz. Dolayısıyla, işverenin işin niteliğiyle ve işin ifasıyla ilgili olarak edinmiş olduğu işçiye veya adaya ait kişisel veri mahiyetindeki bilgileri edinmesi ve kullanması gerek iş ilişkisinin devamı süresince gerekse sonrasında

\footnotetext{
1 Uncular (n 84) 204-205.

92 Gürsel (n 31) 313-314.

93 Gürsel (n 31 ) 318-321.

94 Gürsel (n 31) 323-324.

95 Gürsel (n 31) 244; Uncular (n 84) 150.

96 Uncular (n 84) 189-190.

97 Gürsel (n 31) 244-245; Uncular (n 84) 151.
} 
koruması gerekmektedir. Aksi halde, kişisel verilerin işverence hukuka aykırı olarak elde edilmesi veya kullanılması, ahlak veya iyiniyet kurallarına uymayan eylem olarak nitelendirilebilir ve işçinin işe devamı objektif iyi niyet kuralları gereğince kendisinden beklenemeyecek durumda ise iş sözleşmesinin haklı nedenle feshi gündeme gelebilirr ${ }^{98}$. İstihdam ettiği doktorun bir hırsızlık suçu işlediğine dair bilgiyi bir şekilde edinen ve bu veriyi doktorun personel dosyasında saklayan bir özel hastanenin, daha sonra bu bilgiyi salt doktorun işyerindeki itibarını zedelemek amaciyla kullanması buna örnek verilebilir.

Daha da önemlisi, işin niteliği ve ifasıyla ilgili olarak edinilen işçiye ait kişisel verilerin üçüncü kişilerle paylaşılması, sadece iş̧̧i ve işveren arasındaki güven iliş̧isinin zedelenmesine değil, aynı zamanda BK m.417 uyarınca işçinin kişiliğinin ve kişisel verilerinin korunması borucunu da içeren işçinin kişiliğini koruma ve kişiliğine saygı gösterme yükümlülüğüne de aykırı bir sonuca yol açabilir ve bu aykırılık iş sözleşmesinin devamını çekilmez hale getirdiği ölçüde haklı fesih sebebi olacaktır ${ }^{99}$. Ayrıca, işverenin söz konusu eylemi, KVKK m.12(4) uyarınca veri sorumlusu konumunda olan işverenin sır saklama ve kişisel verileri amacı dışında kullanmama yükümlülüğünün de ihlali anlamına gelecektir ${ }^{100}$. İşçinin kişisel verilerinin korunması hakkına aykırılık neticesinde, işverene karşı maddi tazminat talebinde bulunabileceği gibi, kişilik değerlerine hukuka aykırı saldırı nedeniyle uğramış olduğu manevi zararın tazminini de talep etmesi mümkündür. Hatta sözleşmenin kurulmadığ hallerde dahi işverenin culpa in contrahendo nedeniyle tazminat sorumluluğu gündeme gelebilir ${ }^{101}$.

\section{Uygulanacak Hukukun Tespiti}

\section{a. Uygulanacak Kanunlar İhtilafi Kuralının Tespiti ve Uygulama Alanı}

Yukarıda Türk hukukundan örneklerle, iş sözleşmesi kapsamında elde edilebilecek, kullanılabilecek, saklanması ve korunması gerekecek olan kişisel verilerin neler olabileceğini, bunların işin niteliğiyle ve ifasıyla bağlantılı olarak farklılık arz edebileceğini, işçinin kişisel verilerinin hukuka aykırı olarak işlenmesinin veya korunmamasının ne tür sonuçlar doğuracağını özetlemeye çalıştık. Benzer uyuşmazlıkların, işçinin veya adayın yabancı devlet vatandaşı olduğu veya işverenin yabancı bir gerçek veya tüzel kişi olduğu ya da işin ifa yerinin yabancı ülke olduğu, dolayısıyla iş sözleşmesinin yabancılık unsuru ihtiva ettiği hallerde de ortaya çıkması

\footnotetext{
Uncular (n 84) 314.

99 Gürsel (n 31) 231; Uncular (n 84) 315-316.

100 Gürsel (n 31) 230-231; Uncular (n 84) 318.

101 Gürsel (n 31) 282. Zira işveren, adaya ait kişisel veri niteliğindeki bilgi ve belgeleri, adayın işe kabul edilmemesi halinde adaya iade etmek ve/veya kişisel verileri silmek, yok etmek veya anonim hale getirmekle, şayet ilerideki işe alımlar için bu belgeleri saklamak isterse adayın açık rızasını almakla yükümlüdür.
} 
kuvvetle muhtemeldirr ${ }^{102}$. Bir yabancı şirketin istihdam ettiği bir Türk vatandaşı mühendisin sağlık durumuna veya ceza mahkûmiyetine ilişkin bilgileri üçüncü kişilerle paylaşması nedeniyle işçinin işyeri nezdinde itibarının zedelenmesi buna örnek verilebilir. Böyle bir durumda, iş̧̧inin kişisel verilerinin iş sözleşmesinden kaynaklanan yükümlülüklere aykırı olarak işlendiği veya korunmadığı Türk mahkemelerinde ileri sürüldüğünde, uyuşmazlığın kaynağını teşkil eden iş sözleşmesi yabancılık unsuru ihtiva ettiğinden söz konusu uyuşmazlığın hangi ülke hukukuna göre karara bağlanacağı meselesi ortaya çıkacaktır.

Türk hukukunda yabancılık unsuru içeren iş sözleşmelerinden kaynaklanan uyuşmazlıklara uygulanacak konusunda MÖHUK m.27'de özel bir düzenlemeye yer verilmiştir. $\mathrm{Bu}$ itibarla, işçinin kişisel verilerinin işlenmesinin veya korunmamasının yabancı unsurlu iş sözleşmelerine aykırılık teşkil ettiği iddiası Türk mahkemelerinin önüne geldiğinde, kaynağını iş sözleşmesinden alan bu tür uyuşmazlıkların hangi ülke hukukuna göre karara bağlanacağı, MÖHUK m.27'de yer alan kanunlar ihtilafı kuralları uyarınca belirlenecektir. MÖHUK m.27(1)'de akdi borç ilişkilerine ilişkin diğer MÖHUK hükümleri gibi, sözleşmenin taraflarına hukuk seçimi imkânı tanınmış, hukuk seçiminin yapılmamış olması halinde is şözleşmesine uygulanacak hukukun MÖHUK m.27(2) veya m.27(3)'te yer alan objektif bağlama kurallarına göre tespit edileceği öngörülmüştür. Maddenin son fikrasında ise, Türk mahkemelerine objektif bağlama kuralına göre tespit edilen hukuka nazaran iş sözleşmesiyle daha sıkı ilişkiye sahip hukukun uygulanması imkânı tanıyan bir istisna kuralına yer verilmiştir.

Kişisel verileri işleyen veya paylaşan işverenin yabancı unsurlu iş sözleşmesinden doğan gözetme ve koruma borcuna aykırı davranıp davranmadığı, bu aykırılı̆̆ın iş sözleşmesinin devamını imkânsız hale getirip getirmediği ve dolayısıyla haklı fesih sebebi olup olmadığı, işlenen verinin işin niteliği veya ifasıyla bağlantılı bir veri niteliğinde olup olmadığı gibi hususlar, iş sözleşmesinin esasına yönelik hususlar olması itibariyle bu konular hakkında MÖHUK m.27 uyarınca tespit edilen ülke hukuku karar verecektir. Bu kapsamda, iş̧̧inin kişisel verilerini hukuka aykırı olarak işleyen veya koruma yükümlülüğünü yerine getirmediği tespit edilen işverenin maddi veya manevi tazminat sorumluluğunun doğup doğmadığı ve/veya bu sorumluluğun doğması için gerekli şartların karşılanıp karşılanmadığına ilişkin pek çok meselenin çözümü de, MÖHUK m.27 uyarınca yetkili kılınan hukuka tabidir. Aşağıda bu konuyu ele alacağız.

\section{b. Yetkili Hukukun Taraflarca Belirlenmesi (Hukuk Seçimi)}

Yabancı unsurlu tüketici sözleşmeleri bakımından MÖHUK m.26'da benimsenen bakış açısının MÖHUK m.27'de de benimsendiği görülmektedir. İşverene nazaran

102 Bu konuda farklı örnekler için bkz Zeynep Derya Tarman, 'Yabancılık Unsuru Taşıyan İş Sözleşmelerine Uygulanacak Hukuk' (2010) 59(3) AÜHFD 521, 526. 
ekonomik açıdan daha zayıf konumda olduğu, sözleşmenin müzakeresinde işverenle eşit koşullara sahip olmadığı varsayılan işçilerin korunması ihtiyacını dikkate alan Kanun Koyucunun, MÖHUK m.27'deki düzenlemeyle işçinin işini mutaden yaptığ ülkenin standartları ile korunmasının amaçladığını söyleyebiliriz ${ }^{103}$.

Bu amaçla, ilk olarak MÖHUK m.27(1)'de sınırlı bir hukuk seçimine yer verilmiştir. Buna göre, iş sözleşmeleri, işçinin mutad işyeri hukukunun emredici hükümleri uyarınca sahip olduğu asgari koruma saklı kalmak kaydıyla, tarafların seçtikleri hukuka tabidir ${ }^{104}$. Bu hükümle, yabancı unsurlu iş sözleşmelerine uygulacak hukukun taraflarca serbestçe belirlenebileceği öngörülmüştür ${ }^{105}$. MÖHUK m.26(1)’de taraflara hukuk seçimi imkânı tanınmış olmakla birlikte, seçilen hukukun iş sözleşmesinden kaynaklanan uyuşmazlığa uygulanması, seçilen hukukun işçinin mutad işyeri hukukuna nazaran işçiye daha fazla koruma sağlanması halinde mümkündür. Zira, aynı zamanda MÖHUK m.27(2)'de objektif bağlama kuralı olarak da öngörülen işçinin mutad işyeri hukukunun sağlamış olduğu koruma, MÖHUK m.27(1) uyarınca yapılan hukuk seçimi bakımından asgari düzey olarak belirlenmiştir. Başka bir deyişle, hukuk seçiminin geçerliliği, seçilen hukukun işçiyi koruyucu hükümlerinin mutad işyeri hukukuna göre daha fazla işçi lehine hükümler içermesi, yani hukuk seçiminin işçinin lehine olması şartına bağlanmıştır ${ }^{106}$. Böylece, daha zayıf konumda bulunduğu varsayılan işçinin aleyhine olabilecek bir hukuk seçiminin dayatılabileceği düşüncesiyle, iş sözleşmeleri bakımından sınırlı etkiye sahip bir hukuk seçimine imkân tanınmıştır ${ }^{107}$. Dolayısıyla, tarafların seçmiş oldukları hukuk, işçinin mutad işyerinin bulunduğu ülke hukukunun işçiye sağladığı korumadan daha üst seviyede bir koruma sağlıyorsa, yapılan hukuk seçimi geçerli kabul edilecektir. Buna karşın işçinin mutad işyeri hukukunun işçiye sağladığı koruma, seçilen hukuktan daha üst seviyede ise hukuk seçimi nazara alınmayacaktır ${ }^{108}$.

103 MÖHUK m.27 hükmünün uygulama alanının bireysel iş sözleşmeleri ile sınırlı olduğu kabul edilmektedir. Bkz Doğa Elçin, Milletlerarası Unsurlu Bireysel ve Toplu İs Sözleşmelerine Uygulanacak Hukuk (Adalet 2012) 253ff; Ayşe İpek Sarıöz Büyükalp, 'Mutad İşyeri Kavramı ve MÖHUK m.27/f.3’ün Uygulanması Sorunu' (2018) 8(2) Hacettepe Hukuk Fakültesi Dergisi 195, 199.

104 İşçinin mutad bir işyerinin bulunmadığı haller de söz konusu olabilir. Böyle hallerde asgari koruma standardının hangi hukuka göre belirleneceği konusunda maddede açık bir hüküm yoktur. Doktrinde, bu konuda ortaya çıkacak tereddüdün, MÖHUK m.27(3) hükmünden hareketle çözümlenebileceği, bu itibarla işçinin mutad işyerinin bulunmadığı hallerde yapılan hukuk seçimi bakımından, işverenin esas işyeri hukukunda yer alan hükümlerin asgari koruma standardı olarak kabul edilmesi gerektiği ileri sürülmektedir. Bkz Şanl, Esen ve Ataman-Figanmeşe (n 28) 303 dn.461.

105 MÖHUK m.26(1)'de olduğu gibi, hukuk seçiminin ne şekilde yapılacağı konusunda madde metninde bir açıklık yoktur. Dolayısıyla, genel hüküm niteliğindeki MÖHUK m.24'te yer alan hukuk seçimine ilişkin kurallar MÖHUK'da yer alan her türlü sözleşme bakımından da uygulama alanı bulacağından, hukuk seçimine ilişsin MÖHUK m.24(1)-(3)'de getirilen koşul ve sınırlamaların MÖHUK m.27(1) bakımından da geçerli olduğunu söyleyebiliriz. Bkz Çelikel ve Erdem (n 28) 431; Vahit Doğan, '5718 Sayılı Kanuna Göre İş Akdine Uygulanacak Hukukun Tespiti', (2007) 11(1-2) GÜHFD 147, 154; Tarman, İş Sözleşmesi (n 102) 528.

106 Doğan, $\dot{I}_{S ̧} A k d i$ (n 105) 153

107 Çelikel ve Erdem (n 28) 430; Şanlı, Esen ve Ataman-Figanmeşe (n 28) 303; Nomer (n 28) 345; Tekinalp ve UyanıkÇavuşoğlu (n 28) 420.

108 Çelikel ve Erdem (n 28) 430; Nomer (n 28) 345; Doğan, İş Akdi (n 105) 153; Tarman, İ̧s Sözleşmesi (n 102) 532-533. 
Sınırlı hukuk seçimine izin veren Kanun Koyucu, hukuk seçiminin ne zaman ve hangi şartlarda işçinin lehine olacağını tespit etmemiştir ${ }^{109}$. İş hukuku alanında ekonomik ve sosyal mülahazaların gereği olarak ortaya çıkan ücrete ve izne, çalışma süresi ve şartlarına, sağlık şartlarına, sosyal güvenliğe, iş ilişkisinin sona ermesine ilişkin kamu hukukuna ait pek çok kurala, gerek seçilen hukukta gerekse işçinin mutad işyeri hukukunda yer verilmiş olabilir. Bu bakımdan, seçilen hukuk ile işçinin mutad işyeri hukukundan hangisinin işçiye daha fazla koruma sağladığı konusundaki değerlendirmenin ne şekilde yapılacağı oldukça önem arz etmektedir ${ }^{110}$. Bu noktada, somut bir uyuşmazlıkta söz konusu iki hukuk düzeninden hangisinin işçiyi daha fazla koruduğu, her iki hukuka ait yasal düzenlemelerin genel olarak mukayesesi ile değil, uyuşmazlığa uygulanma ihtimali bulunan kanun hükümlerinin münferit olarak değerlendirilmesiyle yapılması gerektiği ileri sürülmektedir ${ }^{111}$. Bununla birlikte, sadece tatbiki gerekli hüküm bazında tek tek karşılaştırılması yerine, davaya tatbik edilmesi gereken hüküm ile bağlantılı olan hükümlerin bir grup olarak dikkate alınması suretiyle, her iki hukukun karşılaştırılması gerektiği de savunulmaktadır ${ }^{112}$. Örneğin, bir inşaat şirketi, Türk vatandaşı bir inşaat mühendisini Katar'daki ofisinde proje mühendisi olarak çalışmak üzere istihdam etsin ve iş sözleşmesinde sözleşmeden doğabilecek uyuşmazlıkların Türk hukukuna göre çözümleneceği öngörülmüş olsun. İşe alımdan sonra işveren, mühendisin sosyal medya hesaplarındaki beğenilerinden veya paylaşımlarından yola çıkarak onun siyasi görüşü veya cinsel yönelimine ilişkin bilgiler edinmiş ve bunu tasvip etmediğini belirtmiş veya şantiye sahasında çalışabilme yeteneğini etkilemeyecek olmasına rağmen, cinsel yolla bulaşan bir hastalığının varlığını öğrenmiş ve bu bilgiyi işyerinde üçüncü kişilerle paylaşmış olsun. Bunun üzerine, işveren tarafından itibarının zedelendiğini ve kişilik hakkının ihlal edildiğini düşünen mühendis, Türkiye'de işverene karşı iş sözleşmesinin haklı nedenle feshi ile maddi ve manevi tazminat davası açmış olsun. Örneğimizde, işçinin mutad işyeri olan Katar hukukunda yukarıda yer alan işçiye ait olan kişisel verilerin işlenmesi ve bunların paylaşılması hukuken mümkün olabilir. Bu itibarla, bu verilerin işlenmesi, söz konusu hukukta işverenin işçiyi gözetme ve koruma yükümlülüğüne aykırı olmayabilir veya aykırı olsa bile bu aykırılık, yasal olarak iş sözleşmesinin haklı nedenle feshi sebebi olarak öngörülmemiş olabilir. Buna mukabil, taraflarca seçilen hukuk olan Türk hukukunda ise, işçiye ait yukarıdaki bilgiler, hem hassas veri niteliğinde hem de işin niteliğiyle ilgili olmadığından işverence edinilemeyecek veri niteliğindedir. Bu itibarla, Türk hukukunda mühendisin kişisel verilerinin hukuk aykırı olarak işlenmesi ve/veya korun(a)maması, hem iş sözleşmesinden kaynaklanan işçinin kişiliğini gözetme ve koruma borcuna aykırılık teşkil etmekte hem de hem de bu aykırılık, iş sözleşmesinin devamını çekilmez kılması halinde, işçi lehine bir haklı

\footnotetext{
109 Doğan, $\dot{I S S ̧}_{\text {Akdi (n 105) }} 153$.

110 Bu konuda ayrıntılı ve teorik bilgi için bkz Doğan, İş Akdi (n 105) 153-158; Tarman, İş Sözleşmesi (n 102) 530ff

111 Nomer (n 28) 345.

112 Şanl, Esen ve Ataman-Figanmeşe (n 28) 303.
} 
nedenle fesih sebebi sayılmaktadır. Bu örnekten yola çıkacak olursak, seçilen hukuk ile mutad işyeri hukukunun gerek kişisel verilerin korunmasına gerekse bunun iş sözleşmelerine yönelik olan hukuki sonuçlarına ilişkin hükümlerinin bir grup halinde dikkate alınarak bir karşılaştırma yapılması daha yerinde olacaktır.

\section{c. Hukuk Seçimi Yapılmayan Hallerde Sözleşmeye Uygulanacak Hukukun Tespiti (Objektif Bağlama Kuralı)}

MÖHUK m.27(2)'de taraflarca hukuk seçimi yapılmamış olması halinde, iş sözleşmesine işçinin işini mutad olarak yaptığı işyeri hukukunun uygulanacağı öngörülmüştür. Burada yetkili kılınan hukuk, işverenin işyerinin bulunduğu yer değil, işçinin işini yaptığı işyerinin bulunduğu ülke hukukudur ${ }^{113}$. Söz konusu işyerinin işçinin işini mutaden yaptığı işyeri olup olmadığının tespitinde, işin belirli bir anda ifa edildiği yerin önem arz etmediğ ${ }^{114}$, iş sözleşmesi bir bütün olarak ele alınarak, işçinin işini nicelik ve nitelik bakımından ve süre olarak hangi ülkede ağırlıklı şekilde yerine getirdiğinin dikkate alınması gerektiğ $i^{115}$ belirtilmekte, işin esas kısmının ve ağırlıklı bölümünün mutad olarak yapıldığı yer mutad işyeri olarak kabul edilmektedir ${ }^{116}$. Bu bağlamda, MÖHUK m.27(2)'de işçinin işini geçici olarak başka bir ülkede yapması halinde, bu işyerinin mutad işyeri sayılmayacağı özellikle belirtilmiştir. Mesela, şirket merkezinde çalışmakta olan bir mühendisin Katar'daki şantiyede sadece proje bazlı olarak görevlendirilmesi halinde, bu yer işçinin mutad işyeri olmayacaktır.

İşçinin işini mutad olarak belirli bir ülkede yapmasının mümkün olmadığ haller söz konusu olabilir. Örneğin, uluslararası deniz veya havayolu taşıtlarında çalışmakta olan kişiler veya çeşitli ülkelerde konser veya gösteriler yapan turne toplulukları bakımından, mutad işyeri hukukunun tespit edilmesi her zaman mümkün olmayabilir ${ }^{117}$. İşçinin işinin farklı ülkelerde ifa ettiği hallerde, sözleşmenin her iki tarafını belirsizliklere karşı korumak üzere ${ }^{118}$ MÖHUK m.27(3)'de bir diğer bağlama noktasına yer verilmiştir. Buna göre, işçinin işini belirli bir ülkede mutad olarak yapmayıp devamlı olarak birden fazla ülkede yapması halinde, iş sözleşmesinden kaynaklanan uyuşmazlıklara işverenin esas işyeri hukuku uygulanacaktır ${ }^{119}$.

MÖHUK m.27(4)'te, MÖHUK m.27(2) ve m.27(3)'deki kanunlar ihtilafi kurallarını devre dışı bırakan bir istisna kuralına yer verilmiştir. Buna göre, halin bütün şartlarına göre iş sözleşmesiyle daha sıkı ilişkili bir hukukun bulunması halinde,

\footnotetext{
113 Şanl1, Esen ve Ataman-Figanmeşe (n 28) 305.

114 Elçin (n 103) 123.

115 Şanll, Esen ve Ataman-Figanmeşe (n 28) 305; Sarı̈öz Büyükalp (n 103) 206.

116 İşçinin mutad işyeri kavramı hakkında ayrıntılı bilgi için bkz Sarı̈z Büyükalp (n 103) 197ff

117 Çelikel ve Erdem (n 28) 432; Elçin (n 103) 144.

118 Bkz Öztekin Gelgel ve Erdem (n 42) 97-98.

119 Bu konuyla ilgili ayrıntılı bilgi için bkz Doğan, $\dot{I}_{S ̧}$ Akdi (n 105) 161; Tarman, İ̧̧ Sözleşmesi (n 102) 567-568.
} 
sözleşmeye ikinci ve üçüncü fikra hükümleri yerine bu hukuk uygulanabilir. Bu hükümde, MÖHUK'daki akdi borç ilişkileri hakkındaki diğer istisna kurallarından farklı olarak, iş sözleşmesiyle daha sıkı ilişkiye sahip olduğu tespit edilen hukukun uygulanıp uygulanmaması konusunda mahkemenin takdir hakkına sahip olduğu kabul edilmektedir ${ }^{120}$. Buna göre, Türk mahkemeleri, somut olayın özelliklerine göre, işçinin mutad işyeri hukukuna veya (işçinin mutad işyerinin bulunmaması halinde uygulanma imkânı olan) işverenin esas işyeri hukukuna nazaran iş sözleşmesiyle daha sıkı ilişkili bir hukukun var olup olmadığını araştırmak durumunda olduğunu, takdir hakkının ise daha sıkı ilişkili olduğunu tespit ettiği ülke hukukunu uygulayıp uygulamama konusunda olduğunu söyleyebiliriz. Mahkemenin, takdir hakkını kullanırken, ilk olarak işçinin menfaatini gözeterek hareket etmesi gerektiği belirtilmektedir ${ }^{121}$. Örneğin, işçinin mutad işyeri olmak dişında iş sözleşmesiyle herhangi bir irtibatı olmayan yabancı hukuk, daha sıkı ilişkili olan Türk hukukuna nazaran işçinin kişisel verilerinin korunması ile işçinin kişisel verilerinin işveren tarafından korunmaması halinde işçiye tanıdığı haklar bakımından daha az koruma sağlamakta ise, Türk mahkemesi daha sıkı ilişkili hukuk olan Türk hukukunun işçinin menfaatine olduğu gerekçesiyle Türk hukukunu sözleşmeye uygulayabilecektir.

\section{Kişisel Verilerin MÖHUK m.24'ün Kapsamına Giren Yabancı Unsurlu Sözleşmelere Aykırı Olarak İşlenmesi veya Korunmaması Halinde Uygulanacak Hukukun Tespiti}

\section{MÖHUK m.24 Kapsamına Giren ve Kişisel Verileri İşlemeyi Gerektiren veya Koruma Yükümlülüğü Doğurabilecek Sözleşmelerden Örnekler}

Günümüzde gerçek kişilere ait kişisel veri mahiyetindeki bilgilerin işlenmesini gerektiren sözleşme ilişkilerinin çoğunu tüketici sözleşmesi niteliğindeki sözleşmeler ile iş sözleşmelerinin oluşturduğu söylenebilir. Yalnız, gerçek kişilerin tarafı olduğu sözleşmeler sadece tüketici ve iş sözleşmeleri ile sınırlı değildir. MÖHUK'daki akdi borç ilişkilerine uygulanacak hukuku gösteren özel kanunlar ihtilafı kurallarının kapsamına girmeyen, dolayısıyla MÖHUK m.24'ün kapsamına giren yabancı unsurlu sözleşmeler de söz konusu olabilir ve kişisel verilerin bu sözleşmelerin kurulması veya ifası amacıyla işlenmesi gerekebilir. Bu sözleşmelerin en somut örneğini, milletlerarası özel hukukun koruma amacına girmeyen, dolayısıyla MÖHUK m.26'nın kapsamı dışında tutulan kişilerin taşınmasına ilişkin sözleşmeler ile MÖHUK m.26(2)'deki koşulları karşılamayan tüketici sözleşmeleri oluşturmaktadır. Niteliği itibariyle bir tüketici sözleşmesi olan ve konusunu kişilerin taşınmasının oluşturduğu bu sözleşmelerin kurulması ve taşımanın yapılabilmesi, büyük ölçüde

\footnotetext{
120 Tarman, İ̧̧ Sözleşmesi (n 102) 539; Şanl, Esen ve Ataman-Figanmeşe (n 28) 306.

121 Nomer (n 28) 349; Doğan, MÖH (n 28) 397; Tarman, İ̧̧ Sözleşmesi (n 102) 539; Şanl1, Esen ve Ataman-Figanmeşe (n 28) 306.
} 
ilgili gerçek kişinin kişisel verilerinin işlenmesine bağlıdır. Mesela, bir havayolu taşıma şirketinden bilet satın alan bir kişinin kimlik, adres ve iletişim bilgilerini ve/ veya kredi kartı/banka bilgilerini şirket ile paylaşması gerekecektir.

Tüketici sözleşmeleri bahsinde belirttiğimiz üzere, gerçek kişiler, ticari veya mesleki faaliyetlerinde kullanmak üzere mal veya hizmet teminine ilişkin sözleşmeler akdedebilir. Mesela, özel bir muayenehaneye sahip bir diş hekimi ile yabancı bir tıbbi cihaz üreticisi firma arasında tıbbi cihaz satışı, yedek parça ve teknik servis hizmetine ilişkin akdedilen bir sözleşme kapsamında bir önceki örnekte belirttiğimiz bilgilerin burada da işlenmesi gerekecektir. Keza, Türkiye'de saç ekimi uzmanı olan ve kendini Avrupa ülkelerinde de tanıtarak bu ülkelerden de müşteri edinmek isteyen bir doktor, bu amaçla Şampiyonlar Ligi final maçı devre arasında reklamının yayınlanması konusunda söz konusu maçın Avrupa'da yayın haklarını satın alan bir televizyon şirketi ile sözleşme akdetmiş olsun. Bu sözleşme uyarınca yayıncının reklamı hazırlama (yapım) ve yayınlama borcunu ifa edebilmesi, doktorun ismine, mesleğine ve işyerine ilişkin bilgilerin televizyonda görülmesine bağlıdır. Söz konusu reklamın sözleşmede kararlaştırılan süre zarfında veya hiçbir şekilde yayınlamaması halinde, yayıncı sözleşmeden kaynaklanan sorumluluğunu yerine getirmemiş olacaktır.

Gerçek kişilere ait görüntü, ses veya isim gibi pek çok kişisel verinin kullanılma ve bu verilerin hukuka aykırı olarak işlenme ihtimalinin söz konusu olabileceği sözleşmelere bir diğer örnek olarak sponsorluk sözleşmeleri verilebilir. Sponsorun sportif, sanatsal vb. bir alanda faaliyet gösteren bir gerçek kişinin nakdi (belirli bir paranın verilmesi), ayni (malzeme temini) veya hizmet edimleriyle destekleme, desteklenen kişinin ise teşvik aldığı sponsorun tanıtımını yapma borcunu ifa etme, bu kapsamda sponsordan teşvik aldığı faaliyeti icra etme borcu altına girdiği bu sözleşmelerde, sponsorun desteklenen tarafından tanıtımı, kimi hallerde desteklenen gerçek kişinin kişisel veri mahiyetindeki bilgilerinin sponsor tarafindan kullanılmasıyla gerçekleşir ${ }^{122}$. Kanunda düzenlenen veya düzenlemeyen pek çok sözleşmenin unsurlarını barındırabilen bu sözleşmelerde taraflar, destekleyenin sponsoru tanıtma ve bu kapsamda sponsordan teşvik aldığı faaliyeti icra etme borcunun kapsamını, şartlarını ve sınırlarını belirleyebilir. Örneğin, sponsorun tanıtımı amacıyla desteklenenin imza günü ve reklam faaliyetlerine katılması, desteklenenin adı, imzası, fotoğrafı, markası gibi kişisel veya fikri haklarının kullanımının sponsora bırakılması gibi hususlara sözleşmede yer verilebiliir ${ }^{123}$. Böylece, desteklenenin borcunun kapsamı ile sponsorun desteklenene ait kişisel veri mahiyetindeki bilgileri işleyebilmesinin sınırları sözleşmede çizilebilir. Örneğin, kişisel bakım ve kozmetik

\footnotetext{
122 Sponsorluk sözleşmelerinin hukuki niteliği ile sponsor ve desteklenenin hakları ve borçları hakkında ayrıntılı bilgi için bkz Gülçin Elçin Grassinger Sponsorluk Sözleşmesi (Seçkin 2003) 59ff; Kemal Atasoy, Spor Sponsorluğu Sözleșmesinin Hukuki Niteliği (Oniki Levha 2016) 77ff; Ömür Karaağaç, 'Sponsorluk Sözleşmesine Uygulanacak Hukuk' iç Sibel Özel ve Hatice Selin Pürselim Arning (edr), Atipik Sözleşmelere Uygulanacak Hukuk (Oniki Levha 2020) 539, 543-552.

${ }_{123}$ Bkz Karaağaç (n 122) 546.
} 
ürünleri alanında faaliyet gösteren bir Türk şirketi, piyasaya yeni sürdüğü bir ürünün tanıtımı amacıyla yabancı bir futbolcu ile bir sponsorluk sözleşmesi yapmış ve bu anlaşma uyarınca futbolcunun adı ve fotoğraflarının yer aldığ reklamın gazete ve televizyonlarda belirli bir süre yayınlanacağı öngörülmüş olsun. Şirketin, bir süre sonra futbolcunun ismini ve fotoğrafinı diğer ürünlerine/markalarına ilişkin reklamlarda da kullanmaya başlaması, futbolcuya ait kişisel verilerin sözleşmede kararlaştırılan şekilde kullanmaması, dolayısıyla söz konusu verileri hukuka aykırı olarak kullanması anlamına gelecektir.

MÖHUK m.24 kapsamında mütalaa edilebilecek ve bireylerin kişisel verilerinin işlenmesini konu edinen sözleşme türlerine başka bir örnek bulut depolama sözleşmeleridir. Günümüzde büyük boyutlu belge depolamak, bu belgelere her yerden ulaşmak ve bunların kaybolma/zarara uğrama riskinden korumak isteyen kişiler veya kurumlar, gün geçtikçe yaygınlaşan bulut depolama denilen "sanal dolap"ları tercih etmektedir ${ }^{124}$. Başkalarına ait uzakta bulunan sunucularda veri depolamaya yararayan sistem olarak tanımlanan ${ }^{125}$ bulut depolama, bu hizmeti sunan sağlayıc1 (Dpobox, Google Drive, iCloud) ile kullanıcı arasında, kullanıcının kişisel veya kurumsal bilgi, belge ve dosyalarının depolanması, depolanan bu belgelere internet bağlantısı aracılığıyla dilediği zaman ve yerden erişim imkânı sağlanmasına ilişkin bir sözleşmedir ${ }^{126}$. Burada kullanıcı, bir tüketici, tüzel kişi veya kurum olabileceği gibi, bulut depolama hizmetine, ticari veya mesleki faaliyetlerin ifası kapsamında da başvurulabiliir ${ }^{127}$. Örneğin, bir avukat, vekaletini aldığı davalara veya müvekkillerine ilişkin ilişkin her türlü bilgiyi (dava/cevap dilekçeleri, deliller, mahkeme kararları, dava kapsamında yapılan seyahat ve konaklama giderlerini gösteren fatura vb.), mesleki bilgilerini (diploma, ruhsat, sertifika vb.) veya mali bilgilerini, sadece bürosunda değil, bu tür bir bulut depolama sistemi üzerinde sanal olarak arşivleyebilir. Benzer şekilde, bir mimar, mesleğine ve mesleki geçmişine ilişkin her türlü bilgiyi (müşteri bilgilerini, tasarımlarını, projelerini vb.) bu tür sistemler üzerinde depolayabilir. İşte bir tarafını gerçek kişilerin oluşturduğu bu tür sözleşmeler çerçevesinde sağlayıcının, borcunu kesinti veya veri kaybı gibi nedenlerle yerine getirmemesi, depolanan verilerin ifşa edilmesi veya sağlayıcının bu verilere kullanıcının izni olmaksızın erişmesi ve üçüncü kişilerle paylaşması gibi konularda uyuşmazlıklar gündeme gelebilir.

Benzer bir durum, ticari veya mesleki amaçlarla yapılan kimi abonelik sözleşmeleri bakımından da ortaya çıkabilir. Örneğin, Türkiye'de mesleğini yürüten bir avukatın yabancı bir yayınevinin yayınladığı yabancı hukuk kaynaklarına dijital ortamda

\footnotetext{
124 M. Ece Uyanık, 'Bulut Depolama Sözleşmelerine Uygulanacak Hukuk' iç Sibel Özel ve Hatice Selin Pürselim Arning (edr), Atipik Sözleşmelere Uygulanacak Hukuk, (Oniki Levha 2020) 499, 502-503.

125 Bkz Eric Johnson, 'Lost in the Cloud: Cloud Storage, Privacy, and Suggestions for Protecting Users' Data' (2017) 69(3) Stanford Law Review, 867, 872; Uyanık (n 124) 503.

126 Uyanık (n 124) 505.

127 Benzer yönde bkz Uyanık (n 124) 505.
} 
erişebilmek amacıyla söz konusu yayıneviyle bir abonelik sözleşmesi akdedebilir. Sözleşme kapsamında yabancı yayınevinin, avukatın yayınevine ait siteye/veritabanına erişim sağlama borcunu, avukatın da bunun karşılığında ücret ödeme borcunu yerine getirebilmesi, avukata ait kimlik, iletişim, kredi kartı gibi pek çok bilginin yayınevi tarafından kullanılmasıyla mümkün olabilir. Hatta sözleşme kapsamında, avukatın bilgisayarının IP adresinden sisteme ne zaman ve ne kadar süre giriş yaptığına kadar her türlü bilgiyi edinmesi mümkün olabilir. Bir önceki örnekte olduğu gibi, abonelik sözleşmesinin kurulması veya ifası kapsamında aboneye ait kişisel bilgileri kullanmak durumunda olan yayınevinin bu verileri üçüncü kişilerle paylaşması, sözleşmeden kaynaklanan borcunu yerine getirmemesi anlamına gelebilir.

Yukarıdaki örneklerden de anlaşılacağı üzere, gerçek kişilerin tarafi olduğu ve MÖHUK' daki akdi borçilişkilerine ilişkinözel kanunlar ihtilafı kurallarının kapsamına girmeyen, dolayısıyla MÖHUK m.24'ün kapsamına giren pek çok yabancı unsurlu sözleşmenin kurulması için veya bu sözleşmelerden kaynaklanan edimlerin ifasını sağlamak üzere, gerçek kişiye ait kişisel veri mahiyetindeki bilgileri sözleşmenin karşı tarafinca işlenmesi gerekebilir. Kişisel verilerin işlenmesi ile tüketici sözleşmeleri arasındaki ilişkide olduğu gibi, tüketici konumunda olmayan bir gerçek kişiye ait kişisel verilerin işlenmesi, sözleşmeden kaynaklanan asli yükümlülüğün yerine getirilmesini sağlayan bir yan yükümlülük niteliğindedir. Bu verilerin amacı dışında veya yanlış bir şekilde işlenmesi, bu kişilerin sözleşmeden kaynaklanan borcunu tam ve doğru bir şekilde ifa edememesi sonucuna yol açabilecektir ${ }^{128}$. Yukarıda verdiğimiz reklam yayın sözleşmesi örneğinden yola çıkacak olursak, doktorun isminin reklamda yanlış yazılmış veya aynı veya farklı alanda başka bir uzman doktorun ismine ya da fotoğrafına yer verilmiş olması, televizyon şirketinin doktora ait kişisel verileri yanlış işlemesi, dolayısıyla sözleşmeden kaynaklanan borcunu gereği gibi ifa etmemesi sonucunu doğuracaktır. Sponsorluk sözleşmesi örneğinde de, şirketin futbolcunun adına ve fotoğrafına sözleşmede kararlaştırılmayan ürünlerin reklamlarında da kullanması, futbolcuya ait olan ve sponsorluk sözleşmesinin ifasıyla doğrudan ilgili olan kişisel verilerin sözleşmeye aykırı bir şekilde işlemesi, dolayısıyla şirketin/sponsorun sözleşmeye aykırı davranması anlamına gelecektir. Yine, bulut depolama sözleşmesi kapsamında sağlayıcının, kullanıcının kişisel verilerine erişebilme hizmetini kısmen veya belirli bir süreliğine kesmiş olması veya verilerin bir kısmının kullanıcıdan kaynaklanmayan bir nedenle kaybolması halinde, sağlayıcı sözleşmeden kaynaklanan kullanıcının kişisel verilerine erişimi sağlama borcuna aykırı davranmış olacaktır.

Sözleşmenin kurulması veya ifası çerçevesinde satıcı, sağlayıcı veya hizmet sunan tarafından işlenen (elde edilen, depolanan, erişim sağlanan) gerçek kişiye ait kişisel verilerin, yine bu kişilerce korunması da gerekmektedir. Buna göre, sözleşmenin karşı tarafının öncelikle gerçek kişiye ait, sözleşmenin kurulması veya ifasıyla ilgili olmayan kişisel verileri edinmemesi, eğer edinmişse bu verilere zarar vermemesi (yok etmesi, anonim hale getirmesi) veya üçüncü kişilerle paylaşmaması, sözleşmeden

128 Bu konuda bkz Yukarıda III/ B/ 1. 
kaynaklanan bir yükümlülük olan kişisel verileri koruma yükümlülügüünün bir gereği olarak ortaya çıkmaktadır ${ }^{129}$. Sözleşmenin kurulmasıyla veya ifasıyla ilgili olan kişisel verileri işlemek durumunda olan satıcı, sağlayıcı veya hizmet sunan tarafın, gerçek kişiye ait bu bilgileri, veri süjesinin rızası gibi bir hukuka uygunluk sebebi olmadıkça, üçüncü kişilerle paylaşmamaları da gerekmektedir. Mesela bulut depolama sözleşmesinde kullanıcının kişisel verilerine erişebilmesi sağlamakla yükümlü olan sağlayıc1, aynı zamanda sözleşme kapsamında bu verilere izinsiz bir şekilde erişmeyeceği taahhüdüne aykırı davranarak bu verilerin üçüncü kişiler tarafından erişilebilir olmasını sağlamışsa, kullanıcının kişisel verilerini koruma yükümlülüğüne, dolayısıyla sözleşmeye aykırı davranmış olacaktır.

Gerçek kişilerin ticari veya mesleki faaliyetlerini gerçekleştirmek üzere akdetmiş olduğu, dolayısıyla bu kişilerin sözleşmenin kurulmasıyla veya ifasıyla ilgili olan kişisel verilerinin sözleşmenin karşı tarafında işlenmesini gerektiren bu tür sözleşmeler, kimi örneklerimizde de görüldüğü üzere, sözleşmenin bir tarafını yabancı bir gerçek veya tüzel kişinin oluşturması veya sözleşme konusunun veya ifa yerinin yabancı ülkede olması itibariyle yabancılık unsuru ihtiva edebilir. Dolayısıyla, veri sorumlusu konumundaki satıcı, sağlayıcı veya hizmet sunan tarafın, kişisel verileri hukuka aykırı olarak işlediği veya elde ettiği verileri koruma yükümlülüğü ihlal ettiği ileri sürüldüğünde, yabancılık unsuru içeren bu sözleşmelerden doğan uyuşmazlığın hangi ülke hukukuna göre karara bağlacağı meselesi doğacaktır.

\section{Uygulanacak Hukukun MÖHUK m.24 Uyarınca Tespiti ve Uygulama Alanı}

\section{a. Genel Olarak}

Bu başlık altında, MÖHUK' daki akdi borç ilişkilerine ilişkin özel kanunlar ihtilafı kurallarının kapsamına girmeyen, dolayısıyla MÖHUK m.24 kapsamına giren ve kişisel verileri işlemeyi gerektiren ve bu verileri koruma yükümlülüğü doğurabilecek olan yabancı unsurlu sözleşmeleri ele alacağımızı yukarıda dolaylı olarak belirtmiştik. $\mathrm{Bu}$ tür sözleşmelerden doğan -konusunu kişisel verilerin işlenmesi veya korunması yükümlülüğüne aykırılığın oluşturduğu- uyuşmazlıklara uygulanacak hukuk MÖHUK m.24 hükmü uyarınca tespit edilecektir ${ }^{130}$.

\footnotetext{
129 Bu konuda bkz Yukarıda III/ B/ 1 .

130 Dolayısıyla, bu başlık altında MÖHUK'daki akdi borç ilişkilerine dair özel kanunlar ihtilafı kurallarının kapsamına girmeyen sözleşmelere uygulanacak hukukun MÖHUK m.24'ün kapsamına gireceği varsayımından hareket ettiğimizi belirtmeliyiz. Zira yabancı unsurlu bir sözleşmeden kaynaklanan uyuşmazlık Türk mahkemesinin önüne geldiğinde, mahkemenin bu sözleşmeye uygulanacak hukukun MÖHUK m.24-29'da yer alan akdi borç ilişkilerine ilişkin hangi kanunlar ihtilafı kuralına göre tespit edileceğini belirlemeden evvel, uyuşmazlığın kaynaklandığı sözleşmenin hukuki niteliğini belirlemesi, yani vasıflandırma yapması gerekeceği unutulmamalıdır. Türk milletlerarası özel hukukunda da genel kabul edilen yaklașım, vasıflandırmanın lex fori'ye göre yapılacağı yönünde olduğundan, Türk mahkemesi, yabancı unsurlu sözleşmenin Türk maddi hukukunda öngörülen hukuki niteliğini esas alacaktır. Dolayısıyla, yapılacak vasıflandırma sonucunda, uyuşmazlığın kaynaklandığı yabancı unsurlu sözleşmenin MÖHUK m.25 ila m.29'da yer alan borç akitlerine ilişkin özel kanunlar ihtilafı kurallarından birinin kapsamına girmeyen bir sözleşme niteliğinde olmadığı sonucuna varırsa, MÖHUK m.24 hükmünü tatbik edecektir.
} 
MÖHUK m.24 uyarınca yetkili kılınan hukuk, öncelikle sözleşmenin karşı tarafını teşkil eden sağlayıcı, sponsor, hizmet sunan vb. tarafın, sözleşmeye taraf olmakla, sözleşmenin kurulması veya ifası amacıyla gerçek kişiler tarafından sunulan bilgilerin işlenmesi ve/veya korunması şeklinde bir yükümlülük altına girip girmediği hakkında karar verecektir. Kişisel verileri işleme ve/veya koruma yükümlülügünün asli veya yan yükümlülük niteliğinde olup olmadığı, birbirinden farklı bu iki yükümlülüğe aykırılı̆̆ın, aynı zamanda sözleşmenin ihlali sonucunu doğurup doğurmadığı, sözleşmeye aykırılığın hangi hal ve şartlar altında söz konusu olacağı (hukuka uygunluk sebeplerinin neler olduğu) meseleleri de bu hukuka tabi olacaktır. Bununla bağlantılı olarak, sözleşmeye aykırılık halinde, gerçek kişilerin karşı tarafa yönelik maddi veya manevi tazminat talep etmek hakkına sahip olup olmadığ şartlarının neler olduğu gibi meseleler hakkında da karar verecektir.

MÖHUK m.24'te, daha önce incelediğimiz sözleşmelere ilişkin özel kanunlar ihtilafı kurallarında olduğu gibi, uygulanacak hukukun iki şekilde tespit edilebileceğini öngörmüştür. MÖHUK m.24(1)-(3)'de sözleşmeye uygulanacak hukukun taraf iradelerine (hukuk seçimi) istinaden tespit edilebileceği, MÖHUK m.24(4)'te ise hukuk seçiminin yokluğu halinde uygulanacak hukukun objektif bağlama kuralına göre belirleneceği öngörülmüştür.

\section{b. Yetkili Hukukun Taraflarca Belirlenmesi (Hukuk Seçimi)}

MÖHUK m.24(1)-(3) hükümleriyle yabancılık unsuru içeren sözleşmelere uygulanacak hukukun taraflarca hukuk seçimi yoluyla belirlenebilmesine ilişkin koşul ve sınırlamalara yer verilmiş̧ir. Buna göre, taraflar, aralarındaki sözleşmeyi açık olarak seçtikleri hukuka tabi kılabilir. Aynı fikra uyarınca sözleşmenin hükümlerinden ve halin şartlarından tereddüde yer vermeyecek bir biçimde anlaşılabilen bir hukuk seçiminde de bulunabilecektir ${ }^{131}$. Taraflarca seçilen hukuk, gerek emredici gerekse tamamlayıcı ve yorumlayıcı kurallarıyla birlikte, bir bütün olarak sözleşmeye uygulanacaktır ${ }^{132}$. MÖHUK m.24(2)-(3) uyarınca taraflar, seçmiş oldukları devlet hukukunun sözleşmenin bir kısmına veya tamamına uygulanabileceği konusunda anlaşabilecekleri gibi, hukuk seçiminin her zaman yapılabilmesi veya değiştirilebilmesi mümkün kılınmıştır.

\footnotetext{
31 Nomer (n 28) 322; Şanlı, Esen ve Ataman-Figanmeşe (n 28) 276; Çelikel ve Erdem (n 28) 395-396; Doğan, $M O ̈ H$ (n 28) 366-367; Aybay ve Dardağan (n 28) 255-256; Hacı Can ve Ali Gümrah Toker, Milletlerarası Özel Hukuk, (3.Bası, Adalet 2018) 443-445; Nuray Ekşi, Sözleşmeden Doğan Borçlara Uygulanacak Hukuk Hakkında Roma Konvansiyonu (Beta 2004) 100-101; Berk Demirkol, Milletlerarası Özel Hukuk ve Usul Hukuku Hakkında Kanun'un 24. Maddesi Çerçevesinde Sözleşmeye Uygulanacak Hukuk (Vedat 2011) 139ff; Aslı Bayata Canyaş, 'Roma I Tüzüğü ile Milletlerarası Özel Hukuk ve Usul Hukuku Hakkında Kanun Uyarınca Sözleşmeden Doğan Borç İlişkilerinde Örtülü Hukuk Seçimi’ (2011) 1(1) Hacettepe Hukuk Fakültesi Dergisi 110, 110ff; İlyas Arslan, '5718 Sayılı Milletlerarası Özel Hukuk ve Usul Hukuku Hakkında Kanun Uyarınca Sözleşmeden Doğan Borç İlişkilerinde Zımnî Hukuk Seçimi’, (2013) 33(2) MHB 1, 5ff

132 Güngör (n 59) 127; Şanlı, Esen ve Ataman-Figanmeşe (n 28) 273.
} 
Tarafların sözleşmeye uygulanmak üzere seçtikleri hukukun, beliri bir devlet hukuku olması gerekir ${ }^{133}$. Bu bağlamda, seçilen hukuk Türk hukuku veya başka bir devletin hukuku olabilir. Bununla birlikte, sözleşmede belirli bir devlet hukukuna ait olmayan, özellikle milletlerarası ticari hayatı ilgilendiren sözleşmelerde UNIDROIT prensiplerini veya milletlerarası ticari örf adet hukuku (lex mercatoria) kurallarının sözleşme metnine dahil edilmesi (incorporation) ${ }^{134}$ ve akdin bir parçası haline getirilmesi mümkündür. Bu kurallar, taraflarca esasa uygulanmak üzere seçilen veya böyle bir seçim yoksa objektif bağlama kuralı uyarınca belirlenen hukukun sınırları ve temelleri üzerinde uygulanacaktır ${ }^{135}$. Yine, hukuk seçimi yapılması halinde, seçilen hukukun kanunlar ihtilafı kurallarının değil, maddi hukuk kurallarının seçilmiş olduğu kabul edilmektedir. Zaten, gerek MÖHUK m.2(3) gerekse m.2(4) hükümleri birlikte ele alındığında, hukuk seçiminin taraflarca seçilen hukukun kanunlar ihtilafı kuralları değil, sözleşmeye ilişkin maddi hukuk kurallarına yönelik olması gerektiği anlaşılmaktadır ${ }^{136}$.

Bunlara ilaveten, MÖHUK m.24(1)-(3)'de hukuk seçimine ilişkin getirilen sinırlamalar bunlardan ibaret olduğu için, seçilen hukuk ile sözleşmesi arasında objektif olarak herhangi bir bağlantının olmamasının, başka bir deyişle sözleşmeyle hiçbir ilişkisi bulunmayan bir ülke hukukun seçilmesinin mümkün olduğu kabul edilmektedir ${ }^{137}$. Yine, Yargitay'nn bir kararıyla da ortaya konduğu üzere ${ }^{138}$, objektif açıdan yabancılık unsuru içermeyen bir sözleşmeye uygulanmak üzere tarafların yabancı hukukun uygulanacağı konusunda anlaşmış olmaları, sözleşmeye taraf iradesiyle yabancılık unsurunun katılmasını mümkün ve geçerli kılmaktadır ${ }^{139}$.

\section{c. Hukuk Seçimi Yapılmayan Hallerde Sözleşmeye Uygulanacak Hukukun Tespiti (Objektif Bağlama Kuralı)}

Tarafların hukuk seçiminde bulunmamaları halinde sözleşmeye uygulanacak hukukun nasıl belirleneceği MÖHUK m.24(4)’te düzenlenmiştir. Buna göre, taraflarca hukuk seçiminin yapılmamış olması halinde, objektif bağlama kuralı

\footnotetext{
133 Nomer (n 28) 320; Şanll, Esen ve Ataman-Figanmeşe (n 28) 279.

134 Incoprporation hakkında bkz Nuray Ekşi, 'Kanunlar İhtilafı Alanında Incorporation' (1999) 19(1-2) MHB 263, 263ff

135 Şanl, Esen ve Ataman-Figanmeşe (n 28) 279-280. Mesela, uygulanacak hukukun Türk hukuku olduğunu kararlaştıran bir sponsorluk sözleşmesinin tarafları, aynı zamanda ICC'nin Reklamcılık ve Pazarlama İletişim Kodu'nun (ICC Advertising and Marketing Communications Code) "B" Bölümünde yer alan sponsorluğa ilişkin hükümlerin uygulanmasını kararlaştırabilir. Örnek için bkz Karaağaç (n 122) 562.

136 Nomer (n 28) 326; Şanl, Esen ve Ataman-Figanmeşe (n 28) 278.

137 Şanll, Esen ve Ataman-Figanmeşe (n 28) 281.

138 Bkz Yargıtay 11HD, 8585/12877 7.12.2006, (<https://www.lexpera.com.tr> Erişim Tarihi 30 Mart 2020). Kararın detaylı analizi için bkz Emre Esen, 'Critique of a Turkish Court of Cassation Decision on the Validity of Choice-of-Law and Choice of-Forum Clauses in an Insurance Agreement', (2010)(59) Annales de la Faculté de Droit d'Istanbul 365ff; Sibel Özel, ‘Sözleşmesel İlişside Yabancılık Unsuru ve Hukuk Seçimi’ iç Bilgin Tiryakioğlu, Mesut Aygün, Ali Önal, Kübra Altıparmak, Cansu Kaya (edr), Milletlerarası Özel Hukukta Güncel Konular Sempozyumu (Yetkin 2016) 423, 428.

139 Konu hakkındaki teorik tartışmalar hakkında ayrıntılı bilgi için bkz Şanlı, Esen ve Ataman-Figanmeşe (n 28) 283-285; Özel, Hukuk Seçimi (n 138) 423ff
} 
olarak, sözleşmeyle en sıkı ilişkili hukuk uygulanacaktır. Maddenin devamında, sözleşmeyle en sıkı ilişkili hukukun tayininde kullanılmak üzere -emredici niteliktebazı karinelere yer verilmiştir ${ }^{140}$. Dolayısıyla, Türk mahkemeleri, yabancılık unsuru içeren ve konusunu gerçek kişilere ait kişisel verilerin işlenmesi veya bu verilerin korunmaması nedeniyle ihlal edildiği ileri sürülen sözleşmeyle en sıkı ilişkili hukuku bu karineleri kullanmak suretiyle tespit edecektir. MÖHUK m.24(4) c.2'ye göre, karakteristik edim borçlusunun, sözleşmenin kuruluşu sırasındaki mutad meskeni hukuku, ticari veya mesleki faaliyetler gereği kurulan sözleşmelerde karakteristik edim borçlusunun işyeri, bulunmadığı takdirde yerleşim yeri, karakteristik edim borçlusunun birden fazla işyeri varsa sözleşmeyle en sıkı ilişkili bulunan işyeri hukuku, sözleşmeyle en sıkı ilişkili hukuktur.

MÖHUK m.24(4) hükmü, en sıkı irtibatlı hukukun tespitinde kullanılan karineler bakımından, ticari veya mesleki faaliyet çerçevesinde kurulmuş sözleşmelerle böyle bir faaliyet çerçevesinde kurulmuş olmayan sözleşmeler arasında ayrım yapmaktadır. $\mathrm{Bu}$ hüküm uyarınca, karine olarak sözleşmeyle en sıkı ilişkili hukuk, ticari veya mesleki faaliyet çerçevesinde kurulmuş sözleşmeler bakımından, karakteristik edim borçlusunun işyeri, işyerinin bulunmaması halinde yerleşim yeri hukukudur. Ticari veya mesleki faaliyet çerçevesinde kurulmayan sözleşmeler bakımından sözleşmeyle en sıkı ilişkili hukuk karine olarak, karakteristik edim borçlusunun mutad meskeni hukukudur. Demek ki, söz konusu karinelerin hangisinin uygulanacağının tespiti için, öncelikle sözleşmenin ne zaman ticari veya mesleki faaliyet çerçevesinde kurulmuş sayılacağının tespiti gerekmektedir. Mahkemenin önüne gelen uyuşmazlığa konu sözleşmenin ticari veya mesleki bir faaliyet çerçevesinde kurulmuş olup olmadığı, bir vasıflandırma meselesi olup, Türk hukukuna göre belirlenecektir ${ }^{141}$. Mesela, yukarıda verdiğimiz örneklerden doktor ile yabancı yayıncı arasındaki reklam yapım ve yayın, diş hekimi ile tıbbi cihaz üretici yabancı firma arasındaki satım, yabancı futbolcu ile Türk şirket arasındaki sponsorluk veya avukat ile yabancı yayınevi arasındaki abonelik sözleşmelerinin ticari veya mesleki faaliyet çerçevesinde yapıldığını söylemek mümkündür. Dolayısıyla, yabancılık unsuru içeren bu tür sözleşmelerin en sıkı ilişkili olduğu hukuk, karakteristik edim borçlusunun sözleşmenin kuruluşu sırasındaki işyeri, bulunmaması halinde yerleşim yeri, birden fazla işyerinin bulunması halinde sözleşmeyle en sıkı ilişkili işyeri hukuku olacaktır.

MÖHUK m.24(4) uyarınca, sözleşmeyle en sıkı ilişkili hukukun, bu bağlamda maddede yer alan karinelerin doğru bir şekilde uygulanabilmesi, aynı zamanda karakteristik edim borçlusunun sözleşmenin hangi tarafı olduğunun tespitine

\footnotetext{
140 Nomer (n 28) 330; Çelikel ve Erdem (n 28) 398; Doğan, MÖH ( 25) 376; Tekinalp ve Uyanık-Çavuşoğlu (n 28) 365; Şanl, Esen ve Ataman-Figanmeșe (n 28) 291; Can ve Toker (n 131) 450; Aybay ve Dardağan (n 28) 260; Demirkol (n 131) 276ff; Ekşi, Roma (n 131) 109-110.

141 Şanll, Esen ve Ataman-Figanmeşe (n 28) 293.
} 
bağ ${ }_{11} ı{ }^{142}$. Karakteristik edim kavramının yasal bir tarifi bulunmamaktadır ${ }^{143}$. Ancak doktrinde akdi karakterize eden, akde adını ve ağırlığını veren, akde damgasını vuran ve hukukî özelliğini veren, diğerine nazaran daha rizikolu konumda bulunan edim olarak tarif edilmektedir ${ }^{144}$. Bu konuda önerilen bir diğer kriter, para ödenmesine ilişkin edimin karakteristik edim olamayacağıdır ${ }^{145}$. Bu açıklamalar ışığında, yukarıda değindiğimiz mesleki veya ticari faaliyet çerçevesinde kurulan sözleşmelerde karakteristik edimin, bu mesleki veya ticari faaliyet sonucu ortaya çıkan edim olduğunu söyleyebiliriz. Yukarıda verdiğimiz bir gerçek kişinin akdettiği havayoluyla taşıma sözleşmesi örneğinde taşıyanın ediminin, tıbbi cihaz satım sözleşmesinde satıcının, bulut depolama sözleşmesinde depolama altyapısının ve/veya yazılımını kullanıcıya sunan sağlayıcının ${ }^{146}$, abonelik sözleşmesinde yayınevinin ediminin karakteristik edim olduğunu, dolayısıyla bu kişilerin karakteristik edim borçlusu olduğunu söylemek mümkündür. Diğer yandan, tarafların edimleri karşılaştırıldığında bazı sözleşme türleri bakımından karakteristik edimin belirlenmesinin zorluk arz edebilecektir ${ }^{147}$. Mesela, sponsorluk sözleşmelerinde tarafların farklı, karmaşık ve salt para ödenmesine dayanmayan karşılıklı edimlerinin bulunması, hangi tarafının ediminin karakteristik olduğunun belirlenmesini zorlaştırmaktadır. Ancak, sponsorun ediminin sadece para ödenmesi veya ayni ya da hizmet şeklinde bir edim olması karşısında desteklenenin ediminin karakteristik edim olduğu belirtilmektedir ${ }^{148}$. Dolayısıyla, desteklenenin işyeri hukuku, birden fazla işyeri varsa sözleşmeyle en sıkı ilişkili işyeri hukuku, işyerinin bulunmaması halinde yerleşim yeri hukuku, sözleşmeyle en sıkı ilişkili hukuk olacaktır ${ }^{149}$.

MÖHUK m.24(4) hükmü, bir sözleşmeyle en sıkı irtibatlı hukukun hangisi olduğu sorusunu, aynı maddede yer alan karinelerle cevaplamaktadır. Ancak, bu karinelerin uygulanması suretiyle yetkili kılınan hukukun uygulanmasının mutlak olmadığı, MÖHUK m.24(4)'ün son cümlesinde yer alan istisna kuralından anlaşılmaktadır: “... halin bütün şartlarına göre sözleşmeyle daha sıkı ilişkili bir hukukunun bulunması halinde sözleşme, bu hukuka tabi olur”. Demek ki, MÖHUK m.24(4)'deki karineleri uygulamak durumunda olan mahkemenin ulaşmış olduğu hukuk, her zaman gerçek anlamda sözleşmeyle en sıkı ilişkili hukuk olmayabilir ve bu hukuka

\footnotetext{
142 Şanlı, Esen ve Ataman-Figanmeşe (n 28) 293.

143 Karakteristik edim kavramı hakkında ayrıntılı bilgi için bkz Fügen Sargın, 'Karakteristik Edim Teorisine Eleștirel Bir Yaklaşım' (2001) 50(2) AÜHFD 37, 44ff; Güngör Gülin, Temel Milletlerarası Özel Hukuk Metinlerinin Sözleşmeden Doğan Borç İlişkilerine Uygulanacak Hukuk Konusunda Yakınlık Yaklaşımı (Yetkin 2007) 171ff; Demirkol (n 131) 217ff

144 Bkz Nomer (n 28) 331; Sargın (n 143) 45-46; Şanl, Esen ve Ataman-Figanmeşe (n 28) 293-294; Demirkol (n 131) 217-218.

145 Nomer (n 28) 331; Ekși, Roma (n 131) 111-112; Ziya Akıncı, Tarafların Yetkili Hukuku Belirlememeleri Durumunda Sözleşmeye Uygulanacak Hukuk, (Dokuz Eylül Üniversitesi Yayınları 1992) 40.

146 Bu yönde bkz Uyanık (n 124) 514.

147 Bu konu hakkında bkz Şanlı, Esen ve Ataman-Figanmeşe (n 28) 295.

148 Karaağaç (n 122) 565-566.

149 Karaağaç (n 122) 567.
} 
kıyasla sözleşmeyle daha sıkı irtibatlı bir hukukun bulunması söz konusu olabilirr ${ }^{150}$. Dolayısıyla, Türk mahkemeleri somut olayda sadece MÖHUK m.24(4) uyarınca karinelerin uygulamak ve yetkili hukuka ulaşmakla yetinmemeli, en sıkı irtibatlı hukuk olarak tespit edilen bu hukuka nazaran sözleşmeyle daha sıkı ilişkili bir ülke hukukunun var olup olmadığ somut olayın koşullarına göre araştırmalıdır ${ }^{151}$.

\section{Sözleşmeye Uygulanacak Hukuk Olarak Tespit Edilen Yabancı Hukukun Tatbikini Engelleyen Haller}

Kişisel verilerin işlenmesinden veya korunmamasından kaynaklanan yabancı unsurlu sözleşmeye aykırılık iddialarını karara bağlamak durumunda olan bir Türk mahkemesi, yukarıda değindiğimiz kanunlar ihtilafı kurallarını tatbik ettiğinde davaya ya Türk hukukunu ya da yabancı bir ülke hukukunu uygulamak durumunda kalacaktır. Davaya Türk hukukunun maddi hukuk kurallarının uygulanması halinde, esasen herhangi bir problem ortaya çıkmamaktadır. Zira davaya Türk hukukunun uygulanacağının tespiti halinde mahkeme, artık uyuşmazlığ1 yerel karakterli bir dava imiş gibi karara bağlayacaktır. Bu bağlamda, kişisel verilerin işlenmesi veya korunmaması nedeniyle sözleşmenin ihlal edilip edilmediği, kişisel verilerin işlenmesini/korunmamasını hukuka uygun kılan herhangi bir sebebin olup olmadığını, tazminat talep edilmesi halinde bunun şartlarının gerçekleşip gerçekleşmediği gibi hususları, Türk hukukuna göre karara bağlayacaktır. Burada, başta bu konuda özel kanun niteliğinde olan KVKK olmak üzere Türk kanunlarını uygulayacaktır.

Davaya yabancı hukukun uygulanması gerektiği sonucuna varılması halinde, aslolan uyuşmazlığın yetkili kılınan yabancı hukukun maddi hukuk kuralları uyarınca çözümlenmesidir. Bununla birlikte, MÖHUK hükümleri uyarınca yetkili kılınan yabancı hukukun uygulanmasını sınırlandıran iki hâl bulunmaktadır. Bunlardan ilki, yabancı hukukun uygulanmasının Türk kamu düzenine açıkça aykırı olmasıdır. Kişisel verilerin işlenmesi suretiyle gerçekleştiği ileri sürülen gerek kişilik hakkının ihlali gerekse sözleşmeye aykırılık iddialarına ilişkin davaya yabancı hukukun uygulanması gerektiği sonucuna varılması halinde, aslolan bu hukukun davaya tatbik edilmesidir. Bununla birlikte, aslolan yetkili yabancı hukukun davaya tatbik edilmesi olsa da, bu mutlak değildir. Zira yabancı hukukun uygulanması, Türk kamu düzenine aykırı olmaması şartına bağlıdır ${ }^{152}$. Uygulanacak yabancı hukukun somut uyuşmazlığa ilişkin hükmünün uygulanması Türk kamu düzenine açıkça aykırılık

\footnotetext{
150 Şanl1, Esen ve Ataman-Figanmeşe (n 28) 296.

151 Sözleşmeyle en sıkı ilişkili ülke hukukuna nazaran daha sıkı ilişkili hukukun bulunup bulunmadığının tespitinde, hâlin bütün şartlarının dikkate alınması gerekmektedir. Bu çerçevede sözleşmenin ifa veya inikat yerinin, tarafların vatandaşlıklarının, işyerlerinin, mutad meskenlerinin veya yerleşim yerlerinin dikkate alınması gerektiği belirtilmektedir. Bkz Tekinap ve Uyanık-Çavuşoğlu (n 28) 367-368; Şanlı, Esen ve Ataman-Figanmeşe (n 28) 297.

152 Yabancı hukukun tatbikine engel kamu düzeni müdahalesi hakkında bkz Çelikel ve Erdem (n 28) 139ff; Nomer (n 28) 161ff; Şanll, Esen ve Ataman-Figanmeşe (n 28) $75 \mathrm{ff}$
} 
teşkil edecek ise, bu hükmün uygulanmasına engel olunabilir, gerekli görüldüğü takdirde Türk hukuku uygulanır (MÖHUK m.5).

Burada esas alınacak husus, yabancı hukukun uygulanmasıyla ortaya çıkacak sonuçtur. Yabancı hukukun uygulanmasıyla ortaya çıkan sonuç, Türk adap ve ahlak anlayışıla, Türk hukukunun temel prensipleriyle veya temel hak ve özgürlüklerle tahammül edilemez bir şekilde bağdaşmamakta ise, yani kamu düzenini aşikâr bir şekilde ihlal etmekte ise, yabancı hukukun tatbikinden vazgeçilecektir. Dolayısıyla, yukarıda incelediğimiz hükümler uyarınca yetkili kılınan yabancı hukukun somut uyuşmazlığa ilişkin hükmünün uygulanması, Türk kamu düzenine açıķ̧a aykırı bir sonuca yol açmakta ise, bu hükmün uygulanmasına engel olunabilir, gerekli görüldüğ̈̈ takdirde Türk hukuku uygulanır (MÖHUK m.5). Örneğin, MÖHUK m.27(2) uyarınca işçinin mutad işyeri hukuku olan yabancı hukukun iş kanunu hükümlerinde, işçinin çalıştığı işkolu bakımından haklı sebeple dahi olsa iş sözleşmesini feshetme hakkı tanınmamış olsun ${ }^{153}$. İşveren de, söz konusu işçinin bulaşıcı hastalığına veya cinsel yönelimine ya da ceza mahkumiyetine ilişkin bilgilerini kullanarak şantajda bulunmuş veya bunları işyerindeki diğer işçilerin öğreneceği şekilde sosyal medyada paylaşmış olsun. İşçinin işyeri/toplum nezdinde onurunu ve itibarını zedeleyen ve işçinin kişiliğini (kişisel verilerini) koruma ve gözetme borcuna açıkça aykırı olmasına ve işçinin iş sözleşmesine devam etmesinin kendisinden beklenemeyeceği açıkça anlaşılmasına rağmen, salt yetkili yabancı hukukta işçiye iş sözleşmesini feshetme hakkı tanınmaması nedeniyle işçiye işe devam etme zorunluluğu öngören böyle bir kuralın uygulanması, iş̧̧inin maddi ve manevi varlığını koruma ve geliştirme hakkıyla bağdaşmayacağından Türk kamu düzenine açıkça aykırı olarak nitelendirilebilecektir. Yine, sponsorluk sözleşmesine uygulanacak hukuk olarak seçilen yabancı hukukta, sadece sponsora sözleşmeyi fesih hakkı tanınmış olsun. Sponsor bu hakkını kullanmadığı takdirde, öngörülemeyen uzun bir süre boyunca sözleşmeyle bağlı kalacak olan desteklenenin kişisel verileri sponsor tarafından kullanılabilecek, desteklenenin kişisel ve ekonomik özgürlügü aşırı derece sınırlanacaktır. Dolayısıyla, seçilen yabancı hukuktaki ilgili hüküm, kamu düzenine açıkça aykırı olması halinde uygulanmayabilecektir ${ }^{154}$.

Sözleşmeye uygulanacak yabancı hukukun maddi hukuk kurallarının uygulanmasını engelleyen bir diğer hâl de doğrudan uygulanan kurallardır. Devletin organizasyonunu tanzim etmek veya mali, ekonomik, sosyal veya kültürel politikalarını gerçekleştirmek üzere çıkardığı kurallar, hukuki işlem veya ihtilafin niteliğine bakılmaksızın doğrudan uygulama alanı bulmaktadır ${ }^{155}$. Bu kurallar, kamu menfaatini koruma amacını taşıyarak, yabancı unsurlu olsın veya olmasın,

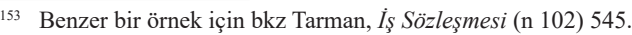

154 Örnek için bkz Karaağaç (n 122) 572.

155 Şanl, Esen ve Ataman-Figanmeşe (n 28) 314; Hatice Özdemir Kocasakal, Doğrudan Uygulanan Kurallar ve Sözleşmeler Üzerindeki Etkileri (Galatasaray Üniversitesi Yayınları 2001) 8. 
ülkeyle irtibatlı her türlü uyuşmazlığa uygulanmaktadır ${ }^{156}$. Burada kamu düzeni müdahalesinden farklı olarak, doğrudan uygulanan kurallar, getirdikleri düzenlemeyle sınırlı olmak kaydıyla, kanunlar ihtilafı kurallarının ve bu kurallar uyarınca yetkili kılınan yabancı hukukun uygulanmasını engellemektedir ${ }^{157}$. Yukarıda zikrettiğimiz hükümler uyarınca sözleşmeye uygulanacak hukuk olarak tespit edilen yabancı hukukun maddi hukuk kurallarının uygulanması, kaynağını 5718 sayılı MÖHUK'ta yer alan düzenlemelerden alan doğrudan uygulanan kuralların uygulanması suretiyle engellenebilir.

Bunlardan ilki olan MÖHUK m.6 uyarınca, yabancı hukukun uygulandığ durumlarda, düzenleme amacı ve uygulama alanı bakımından Türk hukukunun doğrudan uygulanan kurallarının kapsamına giren hallerde o kural doğrudan uygulanır. Bunlardan ikincisi olan ve MÖHUK m.6'dan farklı olarak sadece sözleşmeden kaynaklanan borç ilişkileri bakımından uygulama alanı bulan ${ }^{158}$ MÖHUK m.31 uyarınca, sözleşmenin tabi olduğu hukuk uygulanırken, sözleşmeyle sıkı ilişkili üçüncü devletin doğrudan uygulanan kurallarına etki tanınabilir. Türk mahkemesi, söz konusu kurallara etki tanımak ve uygulayıp uygulamamak konusunda bu kuralların amacını, niteliğini, muhtevasını ve sonuçlarını dikkate alacaktır. Üçüncü olarak, sözleşmeye uygulanacak hukuk olarak tespit edilen yabancı hukukta yer alan doğrudan uygulanan kurallar, MÖHUK m.24 vd. hükümlerinin bir gereği olarak, Türk mahkemelerince uygulanacaktır. Dolayısıyla, kişisel verilerin işlenmesi nedeniyle ortaya çıkan yabancı unsurlu sözleşmeye aykırılık iddiaları hakkında Türk mahkemesi, sözleşmeye uygulanacak yabancı hukukun maddi hukuk kurallarını uygulamadan evvel, yukarıda saydığımız aynı anda üç farklı devletin hukukuna ait doğrudan uygulanan kuralları uygulamak durumunda kalabilecektir.

Bunlardan, MÖHUK m.24 vd. hükümleri uyarınca yetkili kılınan yabancı hukukun doğrudan uygulanan kuralları, yabancı hukukun bir parçası olarak zaten uygulanacaktır. Bununla birlikte, yetkili kılınan yabancı hukukta gerçek kişilerin tarafı olduğu yukarıda zikrettiğimiz sözleşmeler kapsamında elde edilen kişisel verilerin işlenmesine veya korunması konusunda herhangi bir düzenleme bulunmayabilir. Keza, yabancı hukukta kimi kişisel verilerin sözleşmenin karşı tarafinca -sözleşmenin ifasıyla veya kurulmasıly ilgili olsun veya olmasın- elde edilmesi, kullanılması, paylaşılması veya transfer edilmesi herhangi bir koşul aranmaksızın mümkün kılınmış olabilir. Bu gibi durumlarda, gerek Türk hukukunun gerekse sözleşmeyle sıkı ilişkili üçüncü devletin doğrudan uygulanan kurallarının devreye girmesi söz konusu olabilir. Böylece, kişisel verilerin işlenmesine veya korunmasına ilişkin

\footnotetext{
156 Özdemir Kocasakal (n 155) 8; Mustafa Erkan, 'MÖHUK Madde 31 Bağlamında Türk Hukukunda Doğrudan Uygulanan Kurallara Bakış’ (2011) 15(2) GÜHFD 81, 84

157 Şanl1, Esen ve Ataman-Figanmeşe (n 28) 94.

158 Türk hukukunun (lex fori’nin) doğrudan uygulanan kurallarına ilişkin MÖHUK m.6 hükmü, her türlü işlem ve ilişki hakkında uygulama alanı bulacak genel bir hüküm iken, MÖHUK m. 31 hükmü sadece sözleşmeden doğan borç ilişkileri hakkında uygulama alanı bulmaktadır. Bkz Şanlı, Esen ve Ataman-Figanmeşe (n 28) 315.
} 
esnek düzenlemeler getirmesi nedeniyle veri sorumlusu konumundaki sözleşmenin karşı tarafının kişisel verileri işleme veya koruma yükümlülüğüne ilişkin düzenleme getirmeyen veya böyle bir yükümlülük altında bulunmadığı sonucuna yol açan yabancı hukukun maddi hukuk kurallarının uygulanması engellenebilir.

Şüphesiz, bu noktada akla Türk hukukunda var olan ve sözleşmeye uygulanacak yabancı maddi hukuk kurallarının uygulanmasını engelleyen kişisel verilerin işlenmesine ve/veya korunmasına ilişkin kurallardan hangilerinin doğrudan uygulanan kural niteliğinde olduğu sorusu gelmektedir. Bu soruya verilecek cevap, yukarıda zikrettiğimiz sözleşmelerin niteliğine bağlı olarak değişebileceği gibi, KVKK ile kişisel verilerin korunmasına ilişkin diğer düzenlemelerde yer alan bazı kurallar, her türlü hukuki işlem ve ilişki bakımından Türk mahkemelerince dikkate alınması gereken bir doğrudan kural olarak nitelendirilebilir. Örneğin, özel nitelikli kişisel veriler ile bu verilerin işlenmesi şartlarına ilişkin KVKK m.6 hükmünün bir doğrudan uygulanan kural niteliğinde olduğu söylenebilir. Dolayısıyla sözleşme kapsamında işlenen (kullanılan, depolanan, paylaşılan) gerçek kişiye ait kişisel veri, yetkili yabancı hukukta özel nitelikli veri olarak nitelendirmese, hatta bir veri olarak nitelendirilmese dahi, Türk mahkemelerinin bu veriyi bir kişisel veri olarak nitelendirmesi, verinin sözleşmenin karşı tarafınca KVKK m.6'ya uygun olarak işlenip işlenmediğini araştırması gerekecektir.

Yine, kişisel verilerin yurt dışına aktarılmasını ve bunun için gerekli koşulları düzenleyen KVKK m.9 hükmü de bir doğrudan uygulanan kural olarak nitelendirilebilir. Bu itibarla, akdettiği sözleşmeler çerçevesinde gerek çalışanlarına gerekse tüketicilere ait kişisel verileri yurt dişına aktarmak isteyen bir yabancı veya Türk şirketi, sözleşmeye uygulanacak hukuk hangi ülke hukuku olursa olsun, KVKK m.9'da yer alan koşullara uygun olarak hareket etmelidir. Aksi takdirde, yetkili yabancı hukukta kişisel verilerin işlenmesi (veri aktarımı), sözleşmeye aykırı bir davranış olarak nitelendirilmese, dolayısıyla şirketin kişisel verileri koruma yükümlülüğüne aykırı davranmadığı kabul edilse dahi, Türk mahkemesi veri aktarımının KVKK m.9'daki koşullara uygun yapılıp yapılmadığını inceleyebilir ve şirketin sözleşmeye aykırı hareket ettiğine hükmedebilir. Konuyu daha da somutlaştırmak adına, bulut depolama sözleşmeleri üzerinden bir örnek verilebilir. 2019/12 sayılı Cumhurbaşkanlığı Genelgesi ${ }^{159}$ ile bilgilerin dijital ortamlara taşınması, dijital altyapıların ve bilgi yönetim sistemlerinin yaygın olarak kullanılması nedeniyle doğabilecek güvenlik risklerini azaltmak amaciyla bilgi ve iletişim güvenliği için tedbirler alınmıştır. Türk hukukun doğrudan uygulanan kurallarından biri olarak nitelendirilebileceği belirtilen ${ }^{160}$ bu genelgenin ilk maddesinde, nüfus, sağlık ve iletişim kayıt bilgileri ile genetik ve biyometrik bilgilerin yurt içinde

\footnotetext{
159 Bilgi ve İletişim Güvenliği Tedbirleri ile İlgili 2019/12 Sayılı Cumhurbaşkanlığı Genelgesi, Genelge Numarası: 2019/12, Kabul Tarihi: 5.7.2019, RG 6.7.2019/30823.

160 Uyanık (n 124) 526.
} 
depolanacağı düzenlenmiş, kamu kurum ve kuruluşlarının yurt dışındaki sunucularda veri depolaması yasaklanmıştır. Dolayısıyla, söz konusu kişisel verilerin yabancı ülkelerdeki sunucularda depolanmasını ve gerektiğinde kullanılmasını konu edinen bulut depolama sözleşmelerinden kaynaklanan uyuşmazlıklar bakımından, bulut depolama sözleşmelerinin geçerliliğini ve ifasını etkileyebilecek olan bu kural Türk mahkemelerince dikkate alınacaktır.

Türk hukukunun doğrudan uygulanan kurallarının yanı sıra, yukarıda zikrettiğimiz sözleşmelerle sıkı ilişkili olmak kaydıyla, üçüncü devletin doğrudan uygulanan kuralları da yetkili yabancı hukukun sözleşmeye ilişkin maddi kurallarının uygulanmasını engelleyebilir. Bulut depolama sözleşmesi örneğinden yola çıkacak olursak, sözleşmeye yabancı bir devlet hukukunun kararlaştırıldığı, ancak sözleşmeye konu verilerin depolandığı sunucunun bulunduğu ülkenin üçüncü bir ülke olduğu hallerde, üçüncü ülkenin sözleşmeyle sıkı ilişki içinde olduğunu söylemek mümkündür. Dolayısıyla, Türk mahkemesi, sözleşmeyle sık1 ilişki içinde olan üçüncü devletin kişisel verilerin işlenmesine ilişkin genel nitelikteki veya (2019/12 sayılı Genelge gibi) özel düzenlemelerinde yer alan kurallara etki tanıabilir. Bunun sonucunda verilerin hangi ülkede depolandığını bilmeyen kullanıcılar bakımından bulut depolama sözleşmesinin geçerliliğine veya ifasına ilişkin sürpriz sonuçlar ortaya çıkabilir. Zira kişisel verilerin depolanmasına ilişkin bulut altyapılarının yaygınlaşmasıyla birlikte, pek çok ülke hukukunda 2019/12 sayılı Genelge benzeri düzenlemelere yer verildiği belirtilmektedir ${ }^{161}$. Bu bakımdan, yetkili yabancı hukukun, çalışma kapsamında incelediğimiz sözleşmelerden kişisel verilerin işlenmesi veya korunmaması nedeniyle kaynaklanan uyuşmazlıklara uygulanması, sözleşmeyle sıkı ilişkili içindeki üçüncü bir devletin kişisel verilerin işlenmesine veya korunmasına ilişkin doğrudan kuralların varlığı nedeniyle mümkün olmayabilir. Ancak, üçüncü devletin söz konusu kurallarına etki tanımak ve uygulayıp uygulamamak konusunda bu kuralların amacının, niteliğinin, içeriğinin ve sonuçlarının da dikkate alınacağı unutulmamalıdır.

\section{Sonuç}

KVKK ile farklı bir boyut kazanan kişisel verilerin işlenmesi ve korunması, Türk kanunlar ihtilafı hukukunda genellikle kişilik haklarının korunması boyutuyla ele alına gelmiştir. Günümüzde kişisel verilerin işlenmesi ve işlenen bu verilerin korunması gereği, genellikle veri süjesi gerçek kişi ile veri sorumlusu konumundaki karşı taraf arasında akdedilen bir sözleşme çerçevesinde işlenen kişisel veriler bakımından da ortaya çıkabilmektedir. Bu durumda genellikle bir sözleşmenin kurulmasına veya sözleşmenin ifasına ilişkin olarak kişisel verilerin işlenmesi söz konusu olmaktadır.

161 Uyanık (n 124) 528. 
Sözleşmesel ilişki kapsamında elde edilen kişisel verilerin elde edilmesi, kullanılması, depolanması, paylaşılması, aktarılması, silinmesi gibi kişisel veriler üzerindeki her türlü eylem, aynı zamanda ilgili gerçek kişinin şahıs varlığıyla yakından ilgilidir. Bu itibarla, kişisel verilerin hukuka aykırı olarak işlenmesi veya korunmaması, aynı zamanda kişilik haklarına yönelik bir saldırı olması itibariyle haksız fiil olarak da nitelendirilebilmektedir. Türk maddi hukukunda benimsenen haksız fiil sorumluluğu ile akdi sorumluluğun yarışma halinde olduğu ve birbirini dışlamadığı anlayışı Türk kanunlar ihtilafı hukuku bakımından da geçerlidir. Bunun doğal sonucu olarak, yabancı unsurlu sözleşmeler çerçevesinde elde edilen kişisel verilerin hukuka aykırı olarak işlenmesi veya bu verilerin korun(a)maması nedeniyle açılan bir davada, hangi kanunlar ihtilafı kuralının uygulanacağı davacının iddialarını haksız fiil veya sözleşmeye aykırılıktan hangisine dayandıracağına bağlı olarak değişecektir. Kısacası, yabancı unsurlu böyle bir davada uygulanacak kanunlar ihtilafı kuralının tespiti, dolayısıyla hangi ülke hukukunun uygulanacağı, yapılacak böyle bir nitelendirmeye bağlı olarak farklılık arz edecektir. Çalışmamızın kapsamını yabancılık unsuru içeren sözleşmelerin kurulması ve ifasıyla ilgili kişisel verilerin işlenmesi veya bu verilerin veri sorumlusu olan sözleşmenin karşı tarafınca korunmaması nedeniyle ortaya çıkan sözleşmeye aykırılık halleriyle sınırlandırmıştık. Bu itibarla, yabancı unsurlu bu tür sözleşmeye aykırılık iddialarını karara bağlayacak olan Türk mahkemesi, sözleşmeye uygulanacak hukuku MÖHUK m.24-29 ve 32 hükümleri uyarınca belirleyecektir.

MÖHUK m.24-29'da yer alan kanunlar ihtilafı kuralları uyarınca tespit edilen hukuk, sözleşme görüşmelerinden doğan sorumluluk (culpa in contrahendo), sözleşmenin kurulması, maddi geçerliliği, içeriği, yorumu, hüküm ve sonuçları, süresi, irade sakatlıkları, ifa ve ifa engelleri gibi konular hakkında yetkili olacaktır. Gerçek kişilere ait kişisel veriler, sözleşmenin kurulması veya sözleşmeden kaynaklanan edimlerin ifası amacıyla sözleşmenin bir tarafınca işlenmektedir. Dolayısıyla, gerçek kişiler tarafından bu amaçla sunulan veya karşı tarafça istenen bu bilgilerin işlenmesi veya elde edilen bu verilerin korunması konusunda karşı tarafin sözleşmeden kaynaklanan bir yükümlülük altında olup olmadığı veya bu yükümlülüğün kapsamı ve koşulları hakkında da MÖHUK m.24-29 ve 32 uyarınca sözleşmeye uygulanacak hukuk yetkilidir. MÖHUK m.24-29 arasında yer alan kanunlar ihtilafı kurallarından hangisinin uygulanacağ 1 ise, gerçek kişiye ait kişisel verilerin işlenmesini ve korunmasını gerektiren sözleșmenin niteliğine ve taraflarına bağlı olarak değişebilmektedir. MÖHUK m.25-29'da bazı sözleşme türleri bakımından özel kanunlar ihtilafı kurallarına yer verilmiş, MÖHUK m.24'te ise özel kuralların kapsamına girmeyen sözleşmelerden doğan borç ilişkilerine uygulanacak hukuku gösteren genel kanunlar ihtilafı kuralına yer verilmiştir. Dolayısıyla, kişisel verilerin işlenmesi veya korunmaması nedeniyle ihlal edildiği ileri sürülen sözleşme, MÖHUK m.25-29'un kapsamına giren bir sözleşme ise, ilgili özel kural uyarınca uygulanacak hukuk tespit edilecektir. 
Günümüzde, başta tüketici ve iş sözleşmeleri olmak üzere, gerçek kişilerin tarafi olduğu pek çok sözleşmenin kurulabilmesi veya bu sözleşmeler kapsamında karşı tarafın sözleşmeden doğan borçlarını ifa edebilmesi için, veri süjesi konumundaki gerçek kişiye ait kişisel verilerin elde edilmesi, kullanılması, depo edilmesi veya paylaşılması gerekmektedir. Gerçek kişilerin tarafı olabileceği bu tür sözleşmelerin çoğunlukla, tüketici ve iş sözleşmeleri niteliğinde olabileceği düşüncesiyle, konusunu kişisel verilerin işlenmesi veya korunmamasının oluşturduğu bu tür sözleşmelerden doğan uyuşmazlıklara uygulanacak hukukun, MÖHUK m.26 ve m.27 hükümleri uyarınca tespit edileceği sonucuna varılmıştır. MÖHUK m.26 ve m.27 hükümleri analiz edildiğinde, her iki maddedeki kanunlar ihtilafı kuralları, sözleşmenin zayıf tarafi konumunda olduğu varsayılan tüketicileri ve işçileri korumak gayesiyle dizayn edilmiştir. Buna göre, tüketici ve iş sözleşmelerinin taraflarına MÖHUK m.24(1)-(3)'de belirlenen sınırlar dâhilinde hukuk seçiminde bulunma imkânı tanınmıştır. Ancak, hukuk seçimi, seçilen hukukun tüketicinin mutad meskeninin ve işçinin mutad işyerinin bulunduğu ülke hukukunun emredici hükümlerinin sağlayacağı asgari korumaya nazaran daha fazla koruma sağlaması halinde geçerli olacaktır. Hukuk seçiminin yapılmadığı hallerde ise, yabancı unsurlu tüketici ve iş sözleşmelerinden tüketicinin ve işçinin kişisel verilerinin hukuka aykırı olarak işlenmesi veya korunmaması nedeniyle kaynaklanan uyuşmazlıklara, -sırasıylaobjektif bağlama kuralı olarak tüketicinin mutad meskeni hukuku ve işçinin mutad işyeri hukuku uygulanacaktır. Bu noktada, MÖHUK m.27(3) uyarınca işçinin mutad bir işyerinin bulunmadığı hallerde, bu tür uyuşmazlıklara işverenin esas işyeri hukuku uygulanacaktır. Diğer yandan, MÖHUK m.26'dan farklı olarak, MÖHUK m.27(4)'te yer alan istisna kuralı uyarınca mahkeme, halin bütün şartlarına göre iş sözleşmesiyle işçinin mutad işyerine (veya işverenin esas işyerine) nazaran daha sıkı ilişkili bir hukukun bulunması halinde sözleşmeye bu hukuku uygulayabilecektir.

Gerçek kişilerin tarafı olabileceği, dolayısıyla bu kişilere ait kişisel verilerin elde edilmesi, kullanılması, depo edilmesi, paylaşılması gibi veri işleme faaliyetinin söz konusu olabileceği sözleşmeler sadece tüketici ve iş sözleşmeleri ile sınırlı değildir. Gerçek kişilerin, özellikle ticari veya mesleki faaliyet çerçevesinde kullanmak üzere mal ve hizmet teminine ilişkin pek çok sözleşme akdedebilmeleri mümkün olduğu, satım, sponsorluk, reklam yapım ve yayınlama, abonelik veya bulut depolama sözleşmeleri gibi örneklerle ortaya konulmuştur. Gerçek kişilerin tarafı olduğu ve kişisel verilerin işlenmesinin sözleşmenin kurulması ve ifası için gerekli olduğu bu tür yabancı unsurlu sözleşmelerden kişisel verilerin hukuka aykırı olarak işlenmesi veya korunmaması nedeniyle kaynaklanan uyuşmazlıklara uygulanacak hukuk MÖHUK m.24 uyarınca belirlenecektir. Yine, MÖHUK m.26'nın kapsamına girmeyen, ancak niteliği itibariyle bir tüketici sözleşmesi olan gerçek kişilerin tarafı olduğu eşya taşıma sözleşmelerine uygulanacak hukuk, MÖHUK m.29 hükmü uyarınca; konusunu kişilerin taşınmasını oluşturan sözleşmelerle MÖHUK m.26(2)'deki koşullardan 
birini karşılamayan tüketici sözleşmelerine uygulanacak hukuk ise, MÖHUK m.24 uyarınca belirlenecektir.

MÖHUK m.24(1)-(3)'te yer alan koşullar dâhilinde tarafların sözleşmeye uygulanacak hukuku serbestçe belirleyebileceği öngörülmüştür. Dolayısıyla, özel kanunlar ihtilafı kurallarının kapsamına girmeyen sözleşmelerden kişisel verilerin hukuka aykııı olarak işlenmesi veya korunmaması nedeniyle kaynaklanan uyuşmazlığa seçilen hukuk uygulanacaktır. Taraflarca hukuk seçiminde bulunulmaması halinde Türk mahkemesi, MÖHUK m.24(4) uyarınca sözleşmeye sözleşmeyle en sıkı ilişkili hukuku uygulayacaktır. Sözleşmeyle en sıkı ilişkili hukukun tespiti için MÖHUK m.24(4)'te yer alan karinelerin işletilmesi gerekmekte olup, söz konusu karinelerin işletilebilmesi için sözleşmenin ticari veya mesleki faaliyet çerçevesinde kurulmuş olup olmadığı ile karakteristik edim borçlusunun sözleşmenin hangi tarafi olduğu belirleyici olacaktır. Buna göre, Türk mahkemelerinin bir sözleşmenin ticari veya mesleki faaliyet çerçevesinde akdedilmiş olup olmadığını Türk hukukuna göre vasıflandırılacaktır. Sözleşme Türk hukukuna göre ticari veya mesleki bir faaliyet amacıyla yapılan bir sözleşme niteliğinde ise, en sıkı ilişkili hukuk, karakteristik edim borçlusunun işyeri, işyerinin bulunmaması halinde yerleşim yeri hukuku; aksi takdirde karakteristik edim borçlusunun mutad meskeni hukukudur (m.24(4)). Karakteristik edim borçlusun sözleşmenin hangi tarafı olduğu ise, akdi karakterize eden, akde adını ve hukukî özelliğini veren edim olmakla birlikte, kimi sözleşmeler bakımından tarafların edimlerinin eşit ağırlıkta olabileceği ve karakteristik edim borçlusunun sözleşmenin hangi tarafı olduğunun tespitinin zorluk arz edebileceği unutulmamalıdır. Söz konusu karinelere istinaden en sıkı ilişkili hukuka ulaşılsa dahi, bu hukukun uygulanmasının mutlak olmadığı MÖHUK m.24(4)'ün son cümlesinden anlaşılmaktadır. Türk mahkemelerinin, MÖHUK m.24(4)'ün son cümlesindeki istisna kuralı uyarınca halin bütün şartlarına göre en sıkı ilişkili hukuk olarak tespit ettiği hukuka nazaran sözleşmeyle daha sıkı ilişkili hukukun var olup olmadığı somut olayın koşullarına göre araştırması gerekmektedir.

Yabancı unsurlu sözleşmelerden kişisel verilerin hukuka aykırı olarak işlenmesi veya korunmaması nedeniyle kaynaklanan uyuşmazlığa uygulanmak üzere tespit edilen hukuk, ya Türk hukuku ya da yabancı bir ülke hukuku olabilir. Davaya yabancı hukukun uygulanması gerektiği sonucuna varılması halinde, aslolan yabancı hukukun uyuşmazlığa ilişkin maddi hukuk kurallarının uygulanmasıdır. Ancak, iki halde, sözleşmeye uygulanacak hukuk olarak tespit edilen yabancı hukukun uygulanması engellebilir. Bunlardan ilki, yabancı hukukun davaya ilişkin maddi hukuk kurallarının uygulanmasının, Türk kamu düzenine açıkça aykırılık teşkil etmesidir (MÖHUK m.5). Bu durumda, öncelikle yabancı maddi hukuk kuralları davaya uygulanır. Ancak, ortaya çıkan sonuç, Türk adap ve ahlak anlayışı, Türk hukukunun temel prensipleri ve temel hak ve özgürlüklerle tahammül edilemez 
bir şekilde bağdaşmamakta, yani Türk kamu düzenine açıkça aykırı bir sonuca yol açmaktaysa, bu hüküm uygulanmayacaktır.

Yabancı hukukun tatbik edilmesine engel diğer bir hâl de, Türk hukukunun veya sözleşmeyle sıkı ilişkili üçüncü devletin doğrudan uygulanan kurallarının uygulanması nedeniyle yabancı hukukun maddi hukuk kurallarının uygulanmamasıdır. Burada, kamu düzeni müdahalesinden farklı olarak, yabancı maddi hukuk kurallarının uygulanmasıyla elde edilen sonuca bakılmayacaktır. Yetkili kılınan yabancı hukukta yukarıda zikrettiğimiz sözleşmeler çerçevesinde kişisel verilerin işlenmesine veya korunması konusunda herhangi bir düzenleme bulunmayabilir veya bu konuda veri sorumlularına herhangi bir yükümlülük getirilmemiş olabilir. Bu noktada gerek KVKK'da gerekse diğer düzenlemelerde yer alan doğrudan uygulanan kurallar devreye girerek, yabancı hukukun uyuşmazlıkla ilgili maddi hukuk kuralları yerine uygulanabilecektir. Tıpkı Türk hukukunda olduğu gibi, sözleşmeyle sıkı ilişkili olan üçüncü bir devletin hukukunda da kişisel verilerin işlenmesi veya korunmasına ilişkin ve doğrudan uygulanan kural niteliğindeki düzenlemeler bulunabilir. Dolayısıyla, yetkili yabancı hukukun çalışma kapsamında incelediğimiz sözleşmelerden kişisel verilerin işlenmesi veya korunmaması nedeniyle kaynaklanan uyuşmazlıklara uygulanması, sözleşmeyle sıkı ilişkili içindeki üçüncü bir devletin kişisel verilerin işlenmesine veya korunmasına ilişkin doğrudan kurallarına etki tanınması nedeniyle uygulanmayabilir.

Hakem Değerlendirmesi: Dış bağımsız.

Çıkar Çatışması: Yazar çıkar çatışması bildirmemiştir.

Finansal Destek: Yazar bu çalışma için finansal destek almadığını beyan etmiştir. 


\section{Bibliyografya/Bibliography}

Akıncı Z, Tarafların Yetkili Hukuku Belirlememeleri Durumunda Sözleşmeye Uygulanacak Hukuk, (Dokuz Eylül Üniversitesi Yayınları 1992).

Aksoy HC, Medeni Hukuk ve Özellikle Kişilik Hakkı Yönünden Kişisel Verilerin Korunması, (Çakmak 2010).

Arslan İ, '5718 Sayılı Milletlerarası Özel Hukuk ve Usul Hukuku Hakkında Kanun Uyarınca Sözleşmeden Doğan Borç İlişkilerinde Zımnî Hukuk Seçimi', (2013) 33(2) MHB 1-40.

Aşıkoğlu Şİ, Avrupa Birliği ve Türk Hukukunda Kişisel Verilerin Korunması ve Büyük Veri (Oniki Levha 2018).

Atasoy K, Spor Sponsorluğu Sözleşmesinin Hukuki Niteliği (Oniki Levha 2016).

Aybay R ve Dardağan E, Uluslararası Düzeyde Yasaların Çatışması (Kanunlar Ihtilafi) (2.Bası, İstanbul Bilgi Üniversitesi Yayınları 2008).

Aydoğdu M, Tüketici Hukuku Dersleri (Seçkin 2015).

Ayözger Öngün Ç, Kişisel Verilerin Korunması Hukuku, (2.Bası Beta 2019).

Başalp N, Kişisel Verilerin Korunması ve Saklanması (Yetkin 2004).

Bayata Canyaş A, 'Roma I Tüzügü ile Milletlerarası Özel Hukuk ve Usul Hukuku Hakkında Kanun Uyarınca Sözleşmeden Doğan Borç İlişkilerinde Örtülü Hukuk Seçimi’ (2011) 1(1) Hacettepe Hukuk Fakültesi Dergisi 110-121.

Can H ve Toker AG, Milletlerarası Özel Hukuk (3.Bas1, Adalet 2018).

Çalışkan Z, '5718 Sayılı Milletlerarası Özel Hukuk ve Usul Hukuku Hakkında Kanun'un 26. Maddesine Göre Tüketici Sözleşmelerine Uygulanacak Hukuk' (2008) 28(1-2) MHB 27-50.

Çelikel A ve Erdem BB, Milletlerarası Özel Hukuk (15.Bas1, Beta 2020).

Demirkol B, Milletlerarası Özel Hukuk ve Usul Hukuku Hakkında Kanun'un 24. Maddesi Çerçevesinde Sözleşmeye Uygulanacak Hukuk (Vedat 2011).

Doğan V, Milletlerarası Özel Hukuk (4.Bası, Savaş 2016).

Doğan V, ‘5718 Sayılı Kanuna Göre İş Akdine Uygulanacak Hukukun Tespiti’, (2007) 11(1-2) GÜHFD 147-164.

Dülger MV, 'Kişisel Verilerin Korunması Kanunu ve Türk Ceza Kanunu Bağlamında Kişisel Verilerin Ceza Normlariyla Korunması (Ceza Normu)' (2016) 2(3) İMÜHFD 101-167.

Ekşi N, 'Uluslararası Eşya Taşıma Sözleşmelerine Uygulanacak Hukuk (5718 Sayılı MÖHUK md. 29)' Koç Üniversitesi Hukuk Fakültesi Dr. Nüsret-Semahat Arsel Uluslararası Ticaret Hukuku Uygulama ve Araştırma Merkezi Konferans Yayınları Dizisi-2: Avrupa'da Devletler Özel Hukuku ve Yeni Türk Milletlerarası Özel Hukuk ve Usul Hukuku Hakkında Kanun'un Akitler ve Ticaret Hukukuna İlişkin Hükümleri (Legal 2010) 125-170.

Ekşi N, 'Avrupa Birliği Konvansiyonuna Göre Tüketici Sözleşmelerine Uygulanacak Hukuk' (2004) 3(1-2) İKÜHFD 135-153.

Ekşi N, Sözleşmeden Doğan Borçlara Uygulanacak Hukuk Hakkında Roma Konvansiyonu (Beta 2004).

Ekşi N, 'Kanunlar İhtilafi Alanında Incorporation' (1999) 19(1-2) MHB 263-291.

Elçin D, Milletlerarası Unsurlu Bireysel ve Toplu Işs Sözleşmelerine Uygulanacak Hukuk (Adalet 2012).

Eren F, Borçlar Hukuku Genel Hükümler (22.Bas1, Yetkin 2017).

Erkan M, 'MÖHUK Madde 31 Bağlamında Türk Hukukunda Doğrudan Uygulanan Kurallara Bakış’ (2011) 15(2) GÜHFD 81-121. 
Esen E, 'Critique of a Turkish Court of Cassation Decision on the Validity of Choice-of-Law and Choice of-Forum Clauses in an Insurance Agreement', (2010)(59) Annales de la Faculté de Droit d'Istanbul 365-375.

Esenyel Hanaz F, 'Kişilik Haklarının Ihlalinde Sorumluluk ve Uygulanacak Hukuk' (Doktora Tezi İstanbul Üniversitesi 2018).

Etlioğlu Erçetingöz S, 'İnternet Ortamında Şeref ve Haysiyetin Korunmasında Uygulanacak Hukuk' (Yüksek Lisans Tezi, Marmara Üniversitesi 2019).

Grassinger GE, Sponsorluk Sözleşmesi (Seçkin 2003).

Güngör G, Milletlerarası Özel Hukukta Tüketicinin Korunması (Yetkin 2000).

Güngör G, ‘Tüketicinin Mutad Meskeni Hukuku-Düşünsel Temeller' (2008) 57(2) AÜHFD 115-133.

Güngör G, Temel Milletlerarası Özel Hukuk Metinlerinin Sözleşmeden Doğan Borç IIlişkilerine Uygulanacak Hukuk Konusunda Yakınlık Yaklaşımı (Yetkin 2007).

Gürpınar D, 'Kişisel Verilerin Korunamamasından Doğan Hukuki Sorumluluk', (2017) 19(Özel Say1) DEÜHFD (Prof. Dr. Şeref ERTAŞ’a Armağan) 679-694.

Gürsel İ, İşçinin Kişisel Verilerinin Korunması Hakkı (Adalet 2016).

Henkoğlu T, 'Hassas Bilgi Varlıklarının ve Kişisel Verilerin Hukuksal Düzenlemeler ile Korunması ve Bu Kapsamda Üniversiteler İçin Bilgi Güvenliği Politikasının Geliştirilmesi’ (Doktora Tezi, Hacettepe Üniversitesi 2015).

Johnson E, 'Lost in the Cloud: Cloud Storage, Privacy, and Suggestions for Protecting Users' Data' (2017) 69(3) Stanford Law Review, 867-872.

Karaağaç Ö, ‘Sponsorluk Sözleşmesine Uygulanacak Hukuk’ iç Sibel Özel ve Hatice Selin Pürselim Arning (edr), Atipik Sözleşmelere Uygulanacak Hukuk (Oniki Levha 2020) 539-577

Kaya M, Elektronik Ortamda Kişilik Hakkının Korunması, (Seçkin 2015).

Kaya C, 'Avrupa Birliği 1995/46 EC Veri Koruma Direktifi Ekseninde Hassas (Kişisel) Veriler ve İşlenmesi’ (2011) 69(1-2) İÜHFM 317-334.

K1lıçoğlu A, Borçlar Hukuku Genel Hükümler (22.Bası, Turhan 2018).

Kişisel Verileri Koruma Kurumu, Madde ve Gerekçesi ile Kişisel Verilerin Korunması Kanunu (Bilgi Notu) ve Kişisel Verilerin Korunmasına İlişkin Terimler Sözlüğ̈̈ (KVKK Yayınları 2019).

Kişisel Verileri Koruma Kurumu, 6698 Sayılı Kişisel Verilerin Korunması Kanunu Hakkında Sıkça Sorulan Sorular (KVKK Yayınları 2018).

Lloyd IJ, Information Technology Law (6th edn Oxford University Press 2011).

Nomer E, Devletler Hususî Hukuku (22.Bas1, Beta 2018).

Özdemir H, Elektronik Haberleşme Alanında Kişisel Verilerin Özel Hukuk Hükümlerine Göre Korunmasi (Seçkin 2009).

Özdemir Kocasakal H, Doğrudan Uygulanan Kurallar ve Sözleşmeler Üzerindeki Etkileri (Galatasaray Üniversitesi Yayınları 2001).

Özdemir Kocasakal H, Elektronik Sözleşmelerden Doğan Uyuşmazlıkların Çözümüne Uygulanacak Hukukun ve Yetkili Mahkemenin Tespiti (Vedat 2003).

Özel S, Uluslararası Alanda Medya ve İnternette Kişilik Haklarının Korunması (Seçkin 2004) Özel S, 'İnternet Yoluyla Kişilik Hakkı İhlallerinde Uygulanacak Hukuk Meselesi’ (2004) 24(1-2) MHB 609-618. 
Özel S, 'İmalâtçının Sorumluluğu ve Kitle İletişim Araçları Yoluyla Kişilik Hakkının İhlalinde Uygulanacak Hukuk' Koç Üniversitesi Hukuk Fakültesi Dr. Nüsret-Semahat Arsel Uluslararası Ticaret Hukuku Uygulama ve Araştırma Merkezi Konferans Yayınları Dizisi-2: Avrupa'da Devletler Özel Hukuku ve Yeni Türk Milletlerarası Özel Hukuk ve Usul Hukuku Hakkında Kanun'un Akitler ve Ticaret Hukukuna İlişkin Hükümleri (Legal 2010) 219-229.

Özel S, ‘Sözleşmesel İlişkide Yabancılık Unsuru ve Hukuk Seçimi’ iç Bilgin Tiryakioğlu, Mesut Aygün, Ali Önal, Kübra Altıparmak, Cansu Kaya (edr), Milletlerarası Özel Hukukta Güncel Konular Sempozyumu (Yetkin 2016) 423-435.

Öztekin Gelgel G, Akit Dışı Borç İlişkilerine Uygulanacak Hukuk Hakkındaki Avrupa Birliği Düzenlemesi (Beta 2006).

Öztekin Gelgel G, Milletlerarası Özel Hukukta Tüketici Akitlerine İlişkin Sorunlar, (Beta 2004).

Öztekin Gelgel G ve Erdem BB, Milletlerarası Özel Hukuk ve Usul Hukuku Hakkında Kanun (5.Bas1, Beta 2016).

Partalcı R, 'Eşyanın Taşınmasına İlişsin Sözleşmelere Uygulanacak Hukuk Hakkındaki MÖHUK Madde 29'un Değerlendirilmesi' (2017) 37(2) MHB (Prof. Dr. Yücel Sayman'a Armağan) 945-986.

Pürselim HS, 'Milletlerarası Özel Hukukta Tüketici Sözleşmelerine Uygulanacak Hukuk' in Sibel Özel ve Mustafa Erkan (edr), Milletlerarası Özel Hukukta Sözleşmesel Meseleler (Oniki Levha 2018).

Sargın F, 'Karakteristik Edim Teorisine Eleştirel Bir Yaklaşım’ (2001) 50(2) AÜHFD 37-95.

Sarıöz Büyükalp Aİ, ‘Mutad İşyeri Kavramı ve MÖHUK m.27/f.3’ün Uygulanması Sorunu' (2018) 8(2) Hacettepe Hukuk Fakültesi Dergisi 195-248.

Sirmen S, Milletlerarası Özel Hukukta Culpa in Contrahendo Sorumluluğuna Uygulanacak Hukukun Tayini (Yetkin 2016).

Şanlı C, Esen E ve Ataman-Figanmeşe İ, Milletlerarası Özel Hukuk (7.Bası, Beta 2019).

Şen E, 'Kişisel Verilerin Korunması Kanunu Tasarısı'nın Anayasa ve Türk Ceza Kanunu Hükümleri Çerçevesinde Değerlendirilmesi' (2009) 83(3) İBD 1197-1214.

Tarman ZD, 'Milletlerarası Özel Hukukta Tüketicinin Korunması' (2019) 39(1) PPIL 325-356.

Tarman ZD, 'Yabancılık Unsuru Taşıyan İş Sözleşmelerine Uygulanacak Hukuk' (2010) 59(3) AÜHFD 521-550.

Taştan FG, Türk Sözleşme Hukukunda Kişisel Verilerin Korunması (Oniki Levha 2017).

Tekinalp G ve Uyanık-Çavuşoğlu A, Milletlerarası Özel Hukuk-Bağlama Kuralları (11.Bası Vedat 2011).

Toker AG, '5718 Sayılı MÖHUK'ta Düzenlenen Tüketicinin Korunmasına Yönelik Hükümler' (2016) 81(3) İzmir Barosu Dergisi 11-74.

Turan G, 'Elektronik Sözleşmeler ve Elektronik Sözleşmelere Uygulanacak Hukukun Tespiti' (2008) 77 Türkiye Barolar Birliği Dergisi 87-119.

Uncular S, İş Iiş̧kisinde İş̧̧inin Kişisel Verilerinin Korunması (2.Bası, Seçkin 2018).

Uyanık Çavuşoğlu A, 'İnternet Ortamında İşlenen Haksız Fiil Sorumluluğuna Uygulanacak Hukuk’ (2002) 22(2) MHB (Prof. Dr. Ergin Nomer’e Armağan) 967-998.

Uyanık ME, 'Bulut Depolama Sözleşmelerine Uygulanacak Hukuk' iç Sibel Özel ve Hatice Selin Pürselim Arning (edr), Atipik Sözleşmelere Uygulanacak Hukuk (Oniki Levha 2020) 499-538.

Yücedağ N, 'Medeni Hukuk Açısından Kişisel Verilerin Korunması Kanunu'nun Uygulama Alanı ve Genel Hukuka Uygunluk Sebepleri’ (2017) 75(2) İ̈̈HFM 765-790.

Zevkliler A ve Özel Ç, Tüketicinin Korunması Hukuku (Seçkin 2016). 
